Prepared in cooperation with the Kansas Water Office

\title{
Sediment Concentrations and Loads Upstream from and through John Redmond Reservoir, East-Central Kansas, 2010-19
}

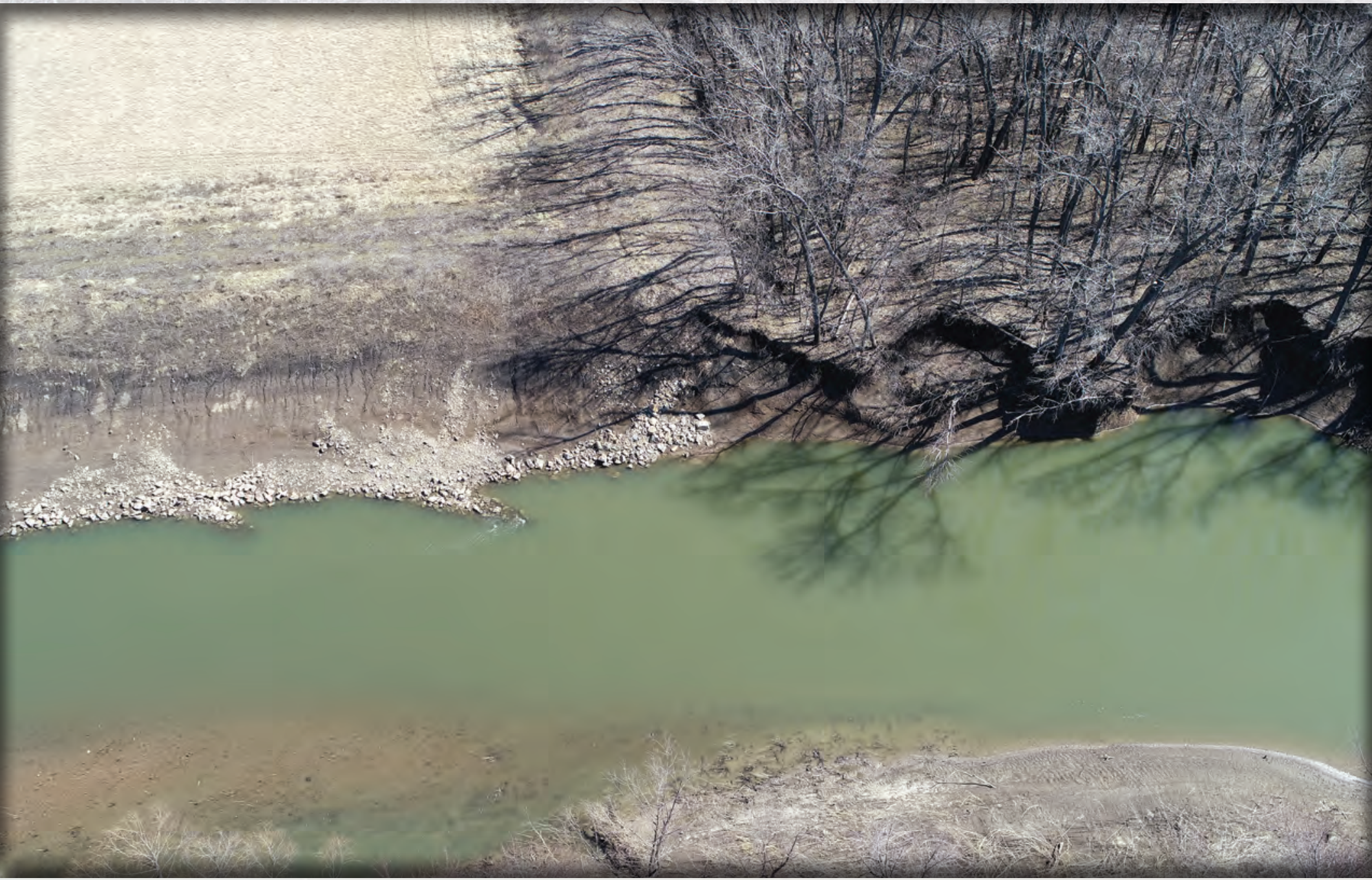

Scientific Investigations Report 2021-5037 
Cover. Photograph showing stabilized versus unstabilized reach of Cottonwood River upstream from the confluence of the Cottonwood and Neosho Rivers, taken by Tony Layzell (Kansas Geological Survey).

Back cover. Top, photograph showing flooded Neosho River near Hartford, Kansas, taken on May 22, 2019, by Ariele Kramer (U.S. Geological Survey [USGS] hydrologist).

Left, photograph showing streambank erosion between rock vanes along the Cottonwood River, taken in October 2019 by Tony Layzell (Kansas Geological Survey).

Right, photograph showing flooded Neosho River downstream from the continuous water-quality monitor installation, taken at the Neosho River at Neosho Rapids, Kansas (USGS site 07182390), on April 27, 2016, by USGS personnel. 


\section{Sediment Concentrations and Loads Upstream from and through John Redmond Reservoir, East-Central Kansas, 2010-19}

By Ariele R. Kramer, Cara L. Peterman-Phipps, Matthew D. Mahoney, and

Bradley S. Lukasz

Prepared in cooperation with the Kansas Water Office

Scientific Investigations Report 2021-5037 


\section{U.S. Geological Survey, Reston, Virginia: 2021}

For more information on the USGS - the Federal source for science about the Earth, its natural and living resources, natural hazards, and the environment-visit https://www.usgs.gov or call 1-888-ASK-USGS.

For an overview of USGS information products, including maps, imagery, and publications, visit https://store.usgs.gov/.

Any use of trade, firm, or product names is for descriptive purposes only and does not imply endorsement by the U.S. Government.

Although this information product, for the most part, is in the public domain, it also may contain copyrighted materials as noted in the text. Permission to reproduce copyrighted items must be secured from the copyright owner.

Suggested citation:

Kramer, A.R., Peterman-Phipps, C.L., Mahoney, M.D., and Lukasz, B.S., 2021, Sediment concentrations and loads upstream from and through John Redmond Reservoir, east-central Kansas, 2010-19: U.S. Geological Survey Scientific Investigations Report 2021-5037, 50 p., https://doi.org/10.3133/sir20215037.

Associated data for this publication:

U.S. Geological Survey, 2020, USGS water data for the Nation: U.S. Geological Survey National Water Information System database, https://doi.org/10.5066/F7P55KJN.

ISSN 2328-0328 (online) 


\section{Acknowledgments}

The authors thank the Kansas Water Office for support related to the publication of this report.

The authors thank Tony Layzell with the Kansas Geological Survey for providing helpful technical reviews and photos for this report.

The authors thank the U.S. Geological Survey staff who assisted with data collection, analysis, and interpretation, including Thomas Williams, Ryan Waters, Justin Abel, Patrick Eslick-Huff, Jon Wedel, and Slade Hackney. David Heimann and Timothy Straub of the U.S. Geological Survey provided helpful reviews that contributed to the technical clarity of this report. 



\section{Contents}

Acknowledgments ……...................................................................................................................

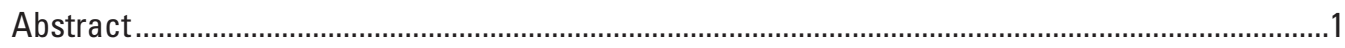

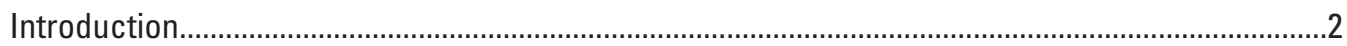

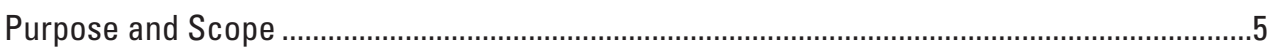

Description of John Redmond Reservoir Drainage Basin ........................................................

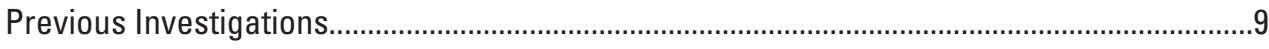

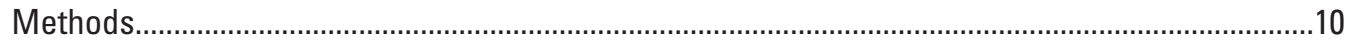

Continuous Water-Quality Monitoring...................................................................................11

Suspended-Sediment Sample Collection and Analysis .........................................................11

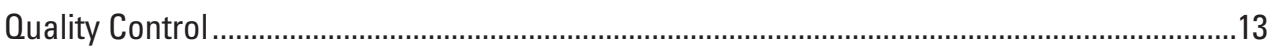

Development of Linear Regression Models ........................................................................14

Suspended-Sediment Concentrations, Loads, and Yields and Streamflow ............................14

Suspended Sediment Transported during High-Flow Events...................................................19

Computation of Streamflow during Backwater Conditions ....................................................20

Streamflow Conditions and Continuously Monitored Water-Quality Variables ...............................20

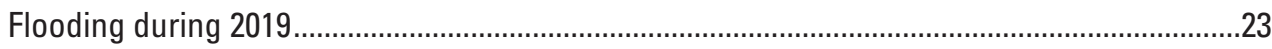

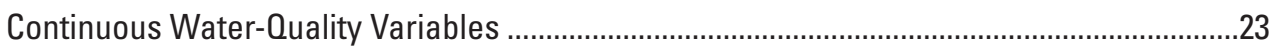

Regression Models and Computed Concentrations, Loads, and Yields for Suspended

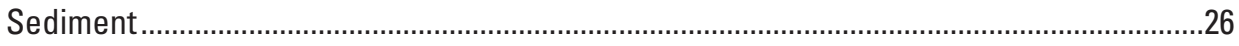

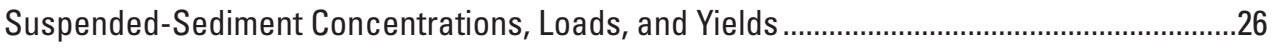

Sediment Trapping in John Redmond Reservoir ......................................................................33

Suspended Sediment Transported during High-Flow Events and Relations to Streambank Stabilization .................................................................................................35

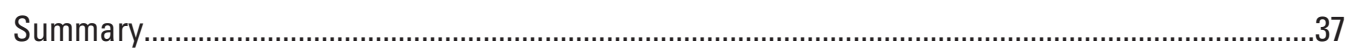

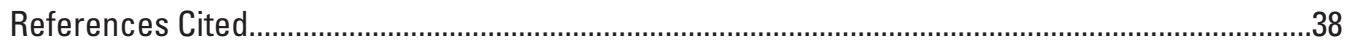

Appendixes 1-12

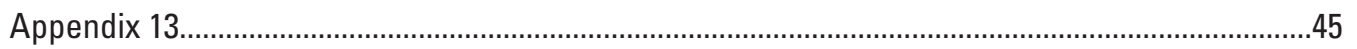

\section{Figures}

1. Map showing location of continuous streamflow and real-time water-quality monitoring sites and land use in the John Redmond Reservoir drainage basin, Kansas

2. Graph showing annual mean precipitation and extreme event precipitation totals for the John Redmond Reservoir drainage basin, Kansas, 2010 through 2019 .......9

3. Graphs showing YSI Incorporated 6600 Extended Deployment System turbidity sensor relation between continuously measured values and cross-sectional means during discrete sample collection for sites on the Cottonwood and Neosho Rivers, Kansas.

4. Graphs showing Xylem YSI EXO, turbidity sensor relation between continuously measured values and cross-sectional means during discrete sample collection for sites on the Cottonwood and Neosho Rivers, Kansas.. 
5. Graph showing streamflow duration curves with 1-, 5-, 95-, and 99-percent exceedances for the study sites along the Cottonwood and Neosho Rivers, Kansas, during 2010 through 2019.

6. Graph showing annual basin mean precipitation totals and annual streamflow for study sites along the Cottonwood and Neosho Rivers, Kansas, during 2010 through 2019 .

7. Graphs showing monthly reservoir-release totals and rainfall totals for Marion Reservoir, Council Grove Lake, and John Redmond Reservoir, Kansas, 2019.

8. Graphs showing duration curves of daily mean turbidity measurements for study sites along the Cottonwood and Neosho Rivers, Kansas, during 2010 through 2019

9. Graphs showing regression relations between YSI Incorporated 6600 Extended Deployment System monitor model 6136 turbidity and suspended-sediment concentrations for study sites along the Cottonwood and Neosho Rivers, Kansas, during 2007 through 2015

10. Graphs showing regression relations between Xylem YSI EX0, model EX02, turbidity and suspended-sediment concentrations for study sites along the Cottonwood and Neosho Rivers, Kansas, during 2015 through 2019

11. Graphs showing regression relations between streamflow and suspended-sediment concentrations for study sites along the Cottonwood and Neosho Rivers, Kansas, during 2007 through 2019.

12. Graph showing duration curves of estimated daily suspended-sediment loads for study sites along the Cottonwood and Neosho Rivers, Kansas, during 2010 through 2019

13. Graph showing estimated sediment loads into and out of John Redmond Reservoir, Kansas, and the resulting load retained in the reservoir during 2010 and 2014-19

\section{Tables}

1. Periods of deployment of YSI 6600 and YSI EXO water-quality monitors at continuous water-quality monitoring sites used in this study.....

2. Continuous water-quality monitoring sites in the John Redmond Reservoir drainage basin, Kansas

3. Annual precipitation totals, extreme event precipitation totals, and counts of extreme precipitation days for Cottonwood Falls, Kansas; Emporia Automated Surface Observing Systems, Kans.; and Lebo, Kans., Global Historical Climatology Network stations

4. Summary statistics for variables measured or computed continuously at Cottonwood River near Plymouth, Kansas; Neosho River at Burlingame Road near Emporia, Kans.; Neosho River at Neosho Rapids, Kans.; and Neosho River at Burlington, Kans., during 2010 through 2019.

5. Summary of quality-control replicate results for discretely collected suspended-sediment concentration replicate data, 2010 through 2019

6. Developed regression models and updated regression models and summary statistics for continuous suspended-sediment concentration computations for Cottonwood River near Plymouth, Kansas; Neosho River at Burlingame Road near Emporia, Kans.; Neosho River at Neosho Rapids, Kans.; and Neosho River at Burlington, Kans 
7. Total annual streamflow and annual mean streamflow for study sites along the

Cottonwood and Neosho Rivers, Kansas, during 2010 through 2019.

8. Monthly reservoir releases, rainfall totals, and site total streamflow computed from daily total streamflow for Council Grove Lake, Marion Reservoir, and John Redmond Reservoir, Kansas, and for each of the streamgage sites, 2019.

9. Suspended-sediment concentrations and suspended-sediment loads computed using daily mean values from regulated and unregulated drainage areas at monitoring sites along the Cottonwood and Neosho Rivers, Kansas.

10. Computed annual mean concentrations, loads, and yields of suspended sediment at monitoring sites on the Cottonwood and Neosho Rivers, Kansas

11. Estimated annual suspended-sediment load upstream and downstream from the reservoir, amount of load retained, and trapping efficiency of John Redmond Reservoir, Kansas.

12. Total suspended-sediment load and suspended-sediment load when streamflow is greater than flood action stage associated streamflow for sites upstream from John Redmond Reservoir, Kansas.

\section{Conversion Factors}

U.S. customary units to International System of Units

\begin{tabular}{|c|c|c|}
\hline Multiply & By & To obtain \\
\hline \multicolumn{3}{|c|}{ Length } \\
\hline inch (in.) & 2.54 & centimeter $(\mathrm{cm})$ \\
\hline inch (in.) & 25.4 & millimeter $(\mathrm{mm})$ \\
\hline foot $(\mathrm{ft})$ & 0.3048 & meter (m) \\
\hline mile (mi) & 1.609 & kilometer $(\mathrm{km})$ \\
\hline \multicolumn{3}{|c|}{ Area } \\
\hline square mile $\left(\mathrm{mi}^{2}\right)$ & 259.0 & hectare (ha) \\
\hline square mile $\left(\mathrm{mi}^{2}\right)$ & 2.590 & square kilometer $\left(\mathrm{km}^{2}\right)$ \\
\hline \multicolumn{3}{|c|}{ Volume } \\
\hline cubic yard $\left(\mathrm{yd}^{3}\right)$ & 0.7646 & cubic meter $\left(\mathrm{m}^{3}\right)$ \\
\hline acre-foot (acre-ft) & 1,233 & cubic meter $\left(\mathrm{m}^{3}\right)$ \\
\hline acre-foot (acre-ft) & 0.001233 & cubic hectometer $\left(\mathrm{hm}^{3}\right)$ \\
\hline \multicolumn{3}{|c|}{ Flow rate } \\
\hline ton per day (ton/d) & 0.01157 & kilogram per second $(\mathrm{kg} / \mathrm{s})$ \\
\hline pound per year (lb/yr) & 0.000124 & kilogram per year (kg/yr) \\
\hline acre-foot per year (acre-ft/yr) & 1,233 & cubic meter per year $\left(\mathrm{m}^{3} / \mathrm{yr}\right)$ \\
\hline acre-foot per year (acre-ft/yr) & 0.001233 & cubic hectometer per year $\left(\mathrm{hm}^{3} / \mathrm{yr}\right)$ \\
\hline cubic foot per second $\left(\mathrm{ft}^{3} / \mathrm{s}\right)$ & 0.02832 & cubic meter per second $\left(\mathrm{m}^{3} / \mathrm{s}\right)$ \\
\hline \multicolumn{3}{|c|}{ Mass } \\
\hline pound, avoirdupois (lb) & 0.4536 & kilogram (kg) \\
\hline ton, short $(2,000 \mathrm{lb})$ & 0.9072 & metric ton $(\mathrm{t})$ \\
\hline
\end{tabular}




\begin{tabular}{|c|c|c|}
\hline Multiply & By & To obtain \\
\hline \multicolumn{3}{|c|}{ Pressure } \\
\hline pound per square mile $\left(\mathrm{lb} / \mathrm{mi}^{2}\right)$ & $1.75133 \times 10^{-7}$ & kilogram per square meter $\left(\mathrm{kg} / \mathrm{m}^{2}\right)$ \\
\hline \multicolumn{3}{|c|}{ Density } \\
\hline pound per cubic foot $\left(\mathrm{lb} / \mathrm{ft}^{3}\right)$ & 16.02 & kilogram per cubic meter $\left(\mathrm{kg} / \mathrm{m}^{3}\right)$ \\
\hline pound per cubic foot $\left(\mathrm{lb} / \mathrm{ft}^{3}\right)$ & 0.01602 & gram per cubic centimeter $\left(\mathrm{g} / \mathrm{cm}^{3}\right)$ \\
\hline
\end{tabular}

International System of Units to U.S. customary units

\begin{tabular}{|c|c|c|}
\hline Multiply & By & To obtain \\
\hline \multicolumn{3}{|c|}{ Length } \\
\hline millimeter $(\mathrm{mm})$ & 0.03937 & inch (in.) \\
\hline
\end{tabular}

Temperature in degrees Celsius $\left({ }^{\circ} \mathrm{C}\right)$ may be converted to degrees Fahrenheit $\left({ }^{\circ} \mathrm{F}\right)$ as follows:

$$
{ }^{\circ} \mathrm{F}=\left(1.8 \times{ }^{\circ} \mathrm{C}\right)+32 .
$$

\section{Datum}

Vertical coordinate information is referenced to the North American Vertical Datum of 1988 (NAVD 88).

Horizontal coordinate information is referenced to the North American Datum of 1983 (NAD 83).

Elevation, as used in this report, refers to distance above the vertical datum.

\section{Supplemental Information}

Specific conductance is given in microsiemens per centimeter at 25 degrees Celsius $\left(\mu \mathrm{S} / \mathrm{cm}\right.$ at $\left.25^{\circ} \mathrm{C}\right)$.

Concentrations of chemical constituents in water are given in milligrams per liter $(\mathrm{mg} / \mathrm{L})$. 


\section{Abbreviations}

$\begin{array}{ll}\text { AEP } & \text { annual-exceedance probability } \\ \text { EPA } & \text { U.S. Environmental Protection Agency } \\ \text { FNU } & \text { formazin nephelometric units } \\ \text { GHCN } & \text { Global Historical Climatology Network } \\ \text { MSPE } & \text { model standard percentage error } \\ n & \text { number of samples } \\ \text { NWS } & \text { National Weather Service } \\ R^{2} & \text { coefficient of determination } \\ \text { RPD } & \text { relative percentage difference } \\ \text { SSC } & \text { suspended-sediment concentration } \\ \text { USGS } & \text { U.S. Geological Survey } \\ \pm & \text { plus or minus }\end{array}$





\title{
Sediment Concentrations and Loads Upstream from and through John Redmond Reservoir, East-Central Kansas, 2010-19
}

\author{
By Ariele R. Kramer, Cara L. Peterman-Phipps, Matthew D. Mahoney, and Bradley S. Lukasz
}

\section{Abstract}

Streambank erosion and reservoir sedimentation are primary concerns of resource managers in Kansas and throughout many regions of the United States and negatively affect flood control, water supply, and recreation. The Cottonwood and upper Neosho Rivers drain into John Redmond Reservoir, and since reservoir completion in 1964, there has been substantial conservation-pool sedimentation and storage loss in John Redmond Reservoir, causing storage capacity losses more rapidly than most other Federal reservoirs in Kansas. The U.S. Geological Survey (USGS), in cooperation with the Kansas Water Office, has monitored water quality (temperature, specific conductance, and turbidity) on the Cottonwood River (upstream from the reservoir) and Neosho River (upstream and downstream from the reservoir) since 2007 with additional sites added in 2009. The purpose of this report is to quantify suspended-sediment concentrations, loads, and yields entering and exiting John Redmond Reservoir during January 1, 2010, through December 31, 2019.

Three water-quality monitoring sites were upstream from the reservoir (Cottonwood River near Plymouth, Kansas [USGS site 07182250; hereinafter referred to as "Cottonwood"]; Neosho River at Burlingame Road near Emporia, Kans. [USGS site 07179750; hereinafter referred to as "Burlingame"]; and Neosho River at Neosho Rapids, Kans. [USGS site 07182390; hereinafter referred to as "Neosho Rapids"]), and one water-quality monitoring site was downstream from the reservoir (Neosho River at Burlington, Kans. [USGS site 07182510; hereinafter referred to as "Burlington"]). The Neosho Rapids streamgage is downstream from the confluence of the Cottonwood and upper Neosho Rivers and has a contributing drainage area accounting for 91 percent of the total contributing drainage area to John Redmond Reservoir.

Continuously measured streamflow, water quality, and discrete water-quality data were used to develop updated regression models to compute suspended-sediment concentrations, loads, and yields upstream and downstream from John Redmond Reservoir in east-central Kansas. Several turbidity sensors were deployed during the analysis period, and there are no established relations between the sensors; therefore, individual models for each sensor were developed. Model statistics for the turbidity and suspended-sediment concentration linear regression models were better (based on the coefficient of determination, root mean square error, and model standard percentage error) than the streamflow and suspended-sediment concentration linear regression models, indicating better model performance. Computed concentrations, loads, and yields do not account for the ungaged 9 percent of the drainage basin downstream from the Neosho Rapids streamgage.

Mean daily suspended-sediment loads upstream from the reservoir were largest at Neosho Rapids (2,250 tons), second largest at Cottonwood (2,180 tons), and smallest at Burlingame (624 tons). Streamflow at Burlington was predominately regulated by reservoir releases, and mean daily suspended-sediment loads were smaller (286 tons) than at upstream sites. Among the upstream sites, Cottonwood had the largest mean daily suspended-sediment concentration (179 milligrams per liter [mg/L]), followed by Neosho Rapids (162 mg/L), and Burlingame (108 mg/L). Burlington had the smallest mean daily suspended-sediment concentration of all sites (46 mg/L).

Annual reservoir trapping efficiency ranged from 82 to 94 percent, and the largest sediment mass trapped was during 2019 (2,230,000 tons). Reservoir storage decreased an estimated 7,750 acre-feet during 2010 and 2014-19. Using the mean trapping efficiency to estimate suspended-sediment loads during years with missing data (2011-13), the total estimated reservoir storage lost to sedimentation for the analysis period (2010-19) was 8,690 acre-feet, about 17 percent of the remaining storage space reported in 2007. The mean annual sedimentation rate during the analysis period ( 747 acre-feet per year) was about 85 percent larger than the design sedimentation rate (404 acre-feet per year) originally projected during construction. Different reservoir outflow management strategies, including operating near normal capacity as opposed to higher flood pool levels, could reduce the total reservoir storage lost by 3 percent (about 261 acre-feet), which is equal to 14 percent of the total sediment removed during the dredging operation in 2016. 
During the study period, about 56 percent of the total suspended-sediment load was transported during streamflows greater than the National Weather Service flood action stage at the upstream sites $(0.1-5$ percent of the record; Cottonwood mean: 48 percent; Burlingame mean: 40 percent; Neosho Rapids mean: 78 percent). Disproportionately large sediment loads were delivered during short periods of time, and localized efforts of stream erosion protection (streambank stabilization, riparian buffers) were likely to be overwhelmed. Precipitation frequency and intensity are projected to continue to increase in this region; therefore, future sediment reduction strategies that account for extreme episodic events may be beneficial. Changes to reservoir outflow management could also minimize sediment accumulation while still preserving flood control. Continued investigation of sediment reduction measures is necessary for future mitigation with the understanding that sedimentation rate is largely driven by high flows. Results from this study can be used to calibrate sediment models, explore sediment reduction strategies, highlight the importance of continued water-quality monitoring to determine effectiveness and changes in sediment transport, and assess the ability of John Redmond Reservoir to support designated uses into the future.

\section{Introduction}

John Redmond Reservoir, in east-central Kansas, has a primarily agricultural drainage basin of about 3,015 square miles $\left(\mathrm{mi}^{2}\right)$ that includes the Cottonwood and upper Neosho Rivers (fig. 1). The reservoir was constructed during 1959 through 1964 for flood control, water supply, and recreation (U.S. Army Corps of Engineers, 2013). Surface water is the primary source of water in the Neosho regional planning area, which includes the Cottonwood and Neosho River Basins and accounts for 86 percent of the total reported water use (54-percent industrial, 33-percent municipal, and 13-percent agriculture and recreation; Kansas Water Office, 2018). Water management plans and systems are an integral part of Kansas water supplies where fresh surface water is predominately stored in reservoirs.

John Redmond Reservoir has a total storage capacity of 816,795 acre-feet (acre-ft) at maximum pool level; about 505,855 acre-ft are available for storage of floodwater (U.S. Army Corps of Engineers, 2016). John Redmond Dam is on the Neosho River 2 miles (mi) northwest of Burlington, Kansas. The dam is equipped with 1440 - by 35 -foot- (ft) high Tainter gates with a spillway capacity at the maximum pool of 428,000 cubic feet per second $\left(\mathrm{ft}^{3} / \mathrm{s}\right)$ at the top of the floodcontrol pool. There are two low-flow pipes with a discharge capacity of $130 \mathrm{ft}^{3} / \mathrm{s}$ at the spillway crest. Bankfull capacity of the channel below the dam site is $15,000 \mathrm{ft}^{3} / \mathrm{s}$ (U.S. Army Corps of Engineers, 2016).
John Redmond Reservoir is losing storage capacity more rapidly than most other Federal reservoirs in Kansas (Jakubauskas and others, 2014; Rahmani and others, 2018; Kansas Water Office, 2019). John Redmond Reservoir was designed using an estimated sedimentation rate of 404 acrefeet per year (acre-ft/yr; U.S. Army Corps of Engineers, 2016). Previously estimated reservoir sedimentation rates exceeded the designed sedimentation rate; U.S. Army Corps of Engineers (2016) estimated a sedimentation rate of 736 acre-ft/yr for 1964-2010, Jakubauskas and others (2014) estimated a sedimentation rate of 492 acre-ft/yr for 2007-14, and Lee and others (2008) estimated a sedimentation rate of $874 \mathrm{acre}-\mathrm{ft} / \mathrm{yr}$ for 2007-8. Excess sedimentation has reduced water availability in the conservation pool by an estimated 42 percent (Kansas Water Office, 2019). A previous study estimated a reduction in water availability in the conservation pool of 41 percent through 2009 with a mean annual loss of 1 percent (Juracek, 2010). By comparison, the reported loss in 2019 indicates a much smaller storage depletion over the last 10 years; however, storage reallocation was approved in 2013, raising the conservation pool $2 \mathrm{ft}$, and the dredging operation concluded in 2016, both restoring water supply lost to sedimentation (about 17,200 acre-ft and 1,860 acre-ft, respectively; U.S. Army Corps of Engineers, 2013; Kansas Water Office, 2017). Water-storage loss affects socioeconomic and cultural resources and allocated water rights for various entities.

Reservoir sedimentation reduces storage capacity and can have lasting effects on flood control, public water supply, habitat for fish and wildlife, and recreation. Sediment and reservoir siltation are environmental concerns because they degrade habitat and water quality (Owens and others, 2005), contribute to declines in aquatic organism populations (Waters, 1995; Henley and others, 2000), and create lower light conditions in the water column, inhibiting growth of some phytoplankton and aquatic macrophytes (Wetzel, 2001; Donohue and Molinos, 2009). The transport of fine-grained sediments through the reservoir system is associated with the transport of adsorbed nutrients, metals, and several other contaminants (Owens and others, 2005; Luoma and Rainbow, 2008).

The U.S. Geological Survey (USGS), in cooperation with the Kansas Water Office, has monitored water quality on the Cottonwood River (upstream from the reservoir) and the Neosho River (upstream and downstream from the reservoir) since 2007 with additional sites added in 2009 (USGS sites 07182250, 07179750, 07182390, and 07182510; fig. 1, table 1). Streamflow at the Cottonwood River near Plymouth, Kans. (USGS site 07182250; hereinafter referred to as "Cottonwood") and Neosho River at Burlington, Kans. (USGS site 07182510; hereinafter referred to as "Burlington") has been continuously measured since 1963 and 1961, respectively (U.S. Geological Survey, 2020). Streamflow at the Neosho River at Burlingame Road near Emporia, Kans. (USGS site 07179750; hereinafter referred to as "Burlingame") and the Neosho River at Neosho Rapids, Kans. (USGS site 07182390; hereinafter referred to as "Neosho Rapids") 


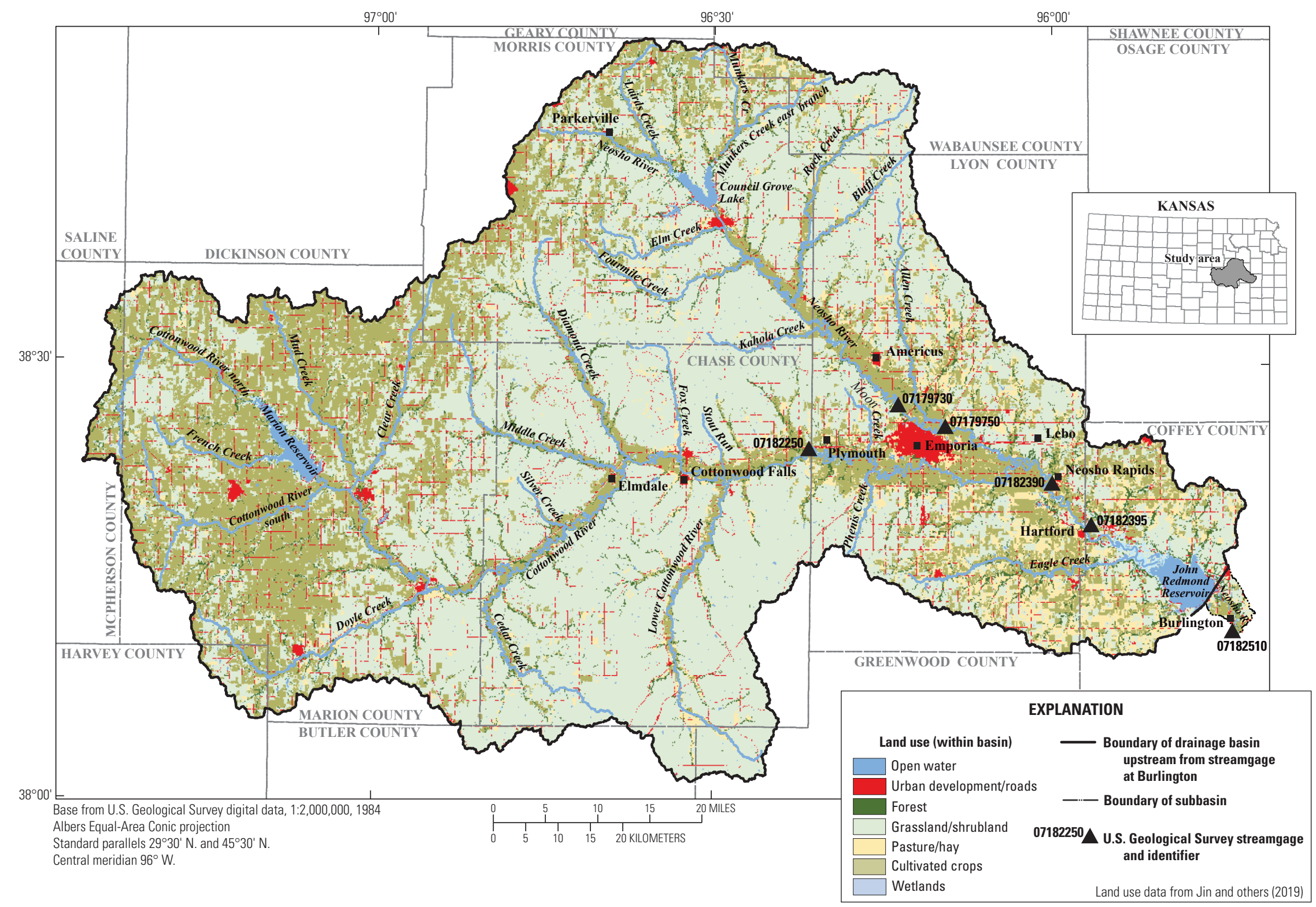

Figure 1. Location of continuous streamflow and real-time water-quality monitoring sites and land use in the John Redmond Reservoir drainage basin, Kansas. 
Table 1. Periods of deployment of YSI 6600 and YSI EXO water-quality monitors at continuous water-quality monitoring sites used in this study.

[Blue shading with bold text indicates period of YSI Incorporated 6600 Extended Deployment System water-quality monitor (YSI 6600) deployment. Green shading with italic text indicates period of Xylem YSI EXO, model EXO2, continuous water-quality monitor (YSI EXO) deployment. Dates shown as month/day/year. USGS, U.S. Geological Survey]

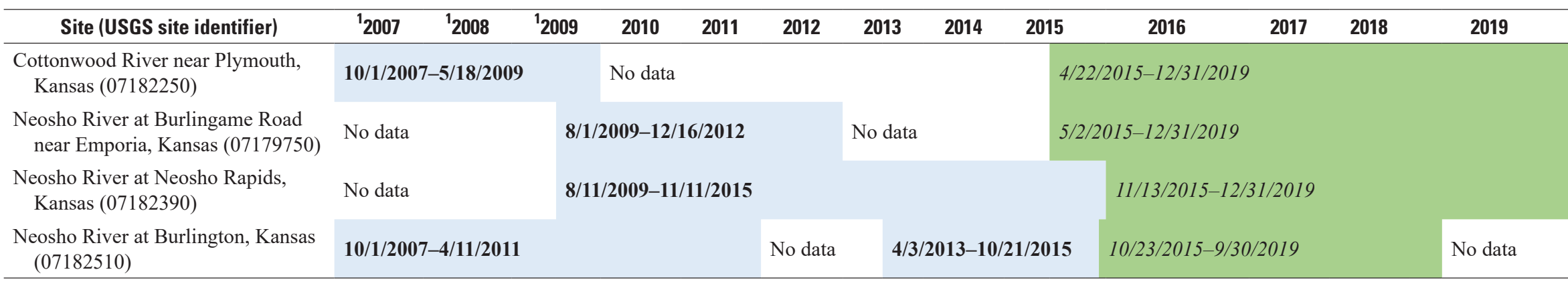

${ }^{1}$ Data during these years were used for model development but were not used for load and concentration computations in this report. 
has been measured since 2009 (U.S. Geological Survey, 2020). Water-quality monitoring at these four sites provided 15-minute measures of water temperature, specific conductance, and turbidity. Discrete water-quality samples have been collected at these sites and used to develop and update regression models establishing relations between continuously monitored water-quality physical properties (turbidity) and water-quality constituents of interest that are not easily monitored (for example, suspended-sediment concentration [SSC]). These models are useful for evaluating concentrations of water-quality constituents to compare with water-quality criteria and for computing loads and yields to assess yields and fluxes.

The Kansas Water Office has identified more than 350 streambank erosion sites along the Cottonwood and Neosho Rivers above the reservoir, and nearly 12 percent of those sites have been stabilized since 2010 by rock structures, bank grading, riprap, and vegetation (Kansas Water Office, 2020). The rock structures were designed to be about $2 \mathrm{ft}$ above the base-flow elevation and extend up and flush with the graded back to thwart the river from flanking the stabilization structures (Watershed Institute, Inc., written commun., 2020). The structures are intended to slow streambank erosion to allow streambank vegetation per plantings and natural regeneration.

\section{Purpose and Scope}

The purpose of this report is to quantify suspendedsediment concentrations and loads entering and exiting John Redmond Reservoir in east-central Kansas during January 1, 2010, through December 31, 2019. Study objectives were met by measuring continuous streamflow and water-quality properties (specifically turbidity) and collecting discrete suspendedsediment samples at three sites upstream from the reservoir and one downstream. Collection of concomitant continuous and discrete data allowed for development of regression models to compute continuous SSC in real time. Suspendedsediment concentrations and loads were computed at multiple locations for the analysis period and used to estimate reservoir trapping efficiency. Results from this study can be used to calibrate sediment models, explore sediment reduction strategies, highlight the importance of continued water-quality monitoring to determine effectiveness and changes in sediment transport, and assess the ability of John Redmond Reservoir to support designated uses into the future. Methods used in this study contribute to an understanding of sediment sources and quantification of reservoir sediment input, throughput, and trapping efficiency that could be applied to other reservoirs regionally, nationally, and globally.

\section{Description of John Redmond Reservoir Drainage Basin}

John Redmond Reservoir drainage basin, in the Osage Plains section of the Central Lowland Province (Schoewe, 1949), covers an area of about $3,015 \mathrm{mi}^{2}$ and drains a part of east-central Kansas. The drainage basin's bedrock is composed of northwesterly dipping strata of alternating limestones and shales of the Upper Pennsylvanian and lower Permian subsystems that overlap one another, tilting toward the west in a stairstep fashion to create cuestas (Buchanan, 1984). One-third of the drainage basin is within the Osage Cuesta physiographic region that is characterized as alternating hard and soft strata with tilted beds that overlap toward the west. The remaining two-thirds are mostly within the Flint Hills, which has a similar westward dipping strata as the Osage Cuesta and, as a result of weathering, sits higher than areas directly east and west (Schoewe, 1949). The Flint Hills Upland topography is characterized as gently rolling.

The Cottonwood River, the major tributary to the Neosho River, drains about 1,900 $\mathrm{mi}^{2}$ and has a river slope of about 3.5 feet per mile (ft/mi) at its headwaters, declining to $1.5 \mathrm{ft} /$ mi near Emporia (Jordan and Hart, 1985; Lee and others, 2008). The Neosho River, excluding the Cottonwood River tributary, drains about $1,110 \mathrm{mi}^{2}$ upstream from the reservoir with slopes ranging from $3 \mathrm{ft} / \mathrm{mi}$ near Council Grove to $1.5 \mathrm{ft} / \mathrm{mi}$ near Emporia (fig. 1; Carswell and Hart, 1985). The Neosho River and major tributaries flow through Quaternary alluvium with soils mostly classified as silty-clay loam (20-70-percent clay, 40 percent or more of silt, and 20 percent or less of sand) or silty clay (40 percent or more of clay, 40 percent or more of silt, and 20 percent or less of sand; U.S. Department of Agriculture, 2019). Erodibility of these soil classes generally is similar (Brady and Weil, 1999).

The Burlingame and Cottonwood streamgages are upstream from the confluence of the Cottonwood and Neosho Rivers. These streamgages are downstream from $2,497 \mathrm{mi}^{2}$ of the approximate $3,015 \mathrm{mi}^{2}$ that drain into the reservoir (table 2; U.S. Army Corps of Engineers, 2002). Council Grove Lake (drainage area of $246 \mathrm{mi}^{2}$ ) and Marion Lake (drainage area of $200 \mathrm{mi}^{2}$ ) regulate streamflow in the basin draining into John Redmond Reservoir. Council Grove Lake impounds 32 percent of the drainage basin upstream from the Burlingame streamgage, and Marion Lake impounds 11 percent of the drainage basin upstream from the Plymouth streamgage. The Neosho Rapids streamgage is downstream from the confluence of the Cottonwood and upper Neosho Rivers and has a contributing drainage area of $2,753 \mathrm{mi}^{2}$, about 91 percent of the total contributing drainage area to John Redmond Reservoir.

The Clean Water Act, section 303(d) authorizes the U.S. Environmental Protection Agency (EPA) to assist States in developing a list of impaired waters that are too degraded or polluted to meet State water-quality standards or exceed total maximum daily load regulations (U.S. Environmental Protection Agency, 33 U.S.C $§ 1251$ et seq., 1972). The 
Table 2. Continuous water-quality monitoring sites in the John Redmond Reservoir drainage basin, Kansas.

[Site information and data available on the National Water Information System website (https://doi.org/10.5066/F7P55KJN; U.S. Geological Survey, 2020); USGS, U.S. Geological Survey; mi ${ }^{2}$, square mile; ${ }^{\text {, }}$ degree; ', minute; ", second; N, north; W, west]

\begin{tabular}{|c|c|c|c|c|c|c|}
\hline $\begin{array}{l}\text { USGS site } \\
\text { identifier }\end{array}$ & Site name & $\begin{array}{c}\text { Total } \\
\text { drainage area } \\
\left(\mathrm{mi}^{2}\right)\end{array}$ & $\begin{array}{l}\text { Unregulated } \\
\text { drainage area } \\
\qquad\left(\mathrm{mi}^{2}\right)\end{array}$ & $\begin{array}{l}\begin{array}{l}\text { Nearest upstream reservoir and } \\
\text { corresponding regulated drainage area } \\
\left(\mathrm{mi}^{2}\right)\end{array}\end{array}$ & Latitude & Longitude \\
\hline 07182250 & $\begin{array}{l}\text { Cottonwood River near Plymouth, } \\
\text { Kansas }\end{array}$ & 1,740 & 1,540 & Marion Lake (200) & $38^{\circ} 23^{\prime} 51^{\prime \prime} \mathrm{N}$ & $96^{\circ} 21^{\prime} 21^{\prime \prime} \mathrm{W}$ \\
\hline 07179750 & $\begin{array}{l}\text { Neosho River at Burlingame Road } \\
\text { near Emporia, Kansas }\end{array}$ & 757 & 511 & Council Grove Lake (246) & $38^{\circ} 25^{\prime} 43^{\prime \prime} \mathrm{N}$ & $96^{\circ} 09^{\prime} 29^{\prime \prime} \mathrm{W}$ \\
\hline 07182390 & $\begin{array}{l}\text { Neosho River at Neosho Rapids, } \\
\text { Kansas }\end{array}$ & 2,753 & 2,307 & $\begin{array}{l}\text { Marion Lake and Council Grove Lake } \\
\text { (446) }\end{array}$ & $38^{\circ} 22^{\prime} 05^{\prime \prime} \mathrm{N}$ & $96^{\circ} 00^{\prime} 00^{\prime \prime} \mathrm{W}$ \\
\hline 07182510 & Neosho River at Burlington, Kansas & 3,042 & 27 & John Redmond Reservoir $(3,015)$ & $38^{\circ} 11^{\prime} 40^{\prime \prime} \mathrm{N}$ & $95^{\circ} 44^{\prime} 40^{\prime \prime} \mathrm{W}$ \\
\hline
\end{tabular}


Cottonwood River near the cities of Elmdale, Emporia, and Plymouth, Kans., has impaired uses for aquatic life and water supply because of total suspended solids, atrazine, sulfate, and total phosphorus (Kansas Department of Health and Environment, 2018a). The Neosho River near the cities of Americus, Neosho Rapids, and Parkerville, Kans., has impaired uses for recreation and aquatic life because of Escherichia coli (E. coli) bacteria, fecal coliform bacteria, copper, and total phosphorus (Kansas Department of Health and Environment, 2018a). John Redmond Reservoir has listed impairments for aquatic life and water supply because of eutrophication, dissolved oxygen, and siltation.

The EPA provides nonenforceable guidelines for States to assist water resource and human health protection. The Cottonwood and Neosho Rivers, upstream from the reservoir, are within level III ecoregion IV subregion 28 (Flint Hills) and ecoregion IX subregion 40b (Osage Cuestas) (U.S. Environmental Protection Agency, 2000, 2001). EPA turbidity reference conditions are 19.5 formazin nephelometric units (FNU) in ecoregion 28 and 15.5 FNU in ecoregion 40b (U.S. Environmental Protection Agency, 2000, 2001).

Land use in the study area is mostly grassland (56 percent) and agriculture, and agricultural lands are devoted to row-crop farming (26 percent) and areas reserved for pasture/hay (6 percent; fig. 1; Jin and others, 2019). During 2001 through 2016, urban development increased 2 percent and cultivated cropland increased 3 percent, whereas forest $(-1$ percent), grassland ( -1 percent $)$, pasture $(-2$ percent $)$, and wetlands ( -4 percent) land cover all decreased in the study area (Homer and others, 2004; Jin and others, 2019). Although erosion is a natural process through the actions of rain, wind, and the freezing and thawing of soil, excess erosion can result from anthropogenic activities. The effects of crop cultivation on streams include a loss of riparian vegetation and an associated increase in bank erosion that can degrade streams and reduce downstream reservoir storage capacity (Fox and others, 2016; Rahmani and others, 2018).

Daily precipitation during the analysis period was available from multiple Global Historical Climatology Network (GHCN) stations in the drainage basin including Cottonwood Falls, Kans. (GHCND:USC0141858); Emporia Automated Surface Observing Systems in Emporia, Kans. (GHCND:USW00013989); and Lebo, Kans. (GHCND:USC0144608; Menne and others, 2012b) (fig. 1). Precipitation totals can vary spatially; therefore, to better summarize precipitation in the basin, annual precipitation totals from the three GHCN stations were averaged. The mean annual precipitation during 2010 through 2019 was 35.4 inches (in.). Annual mean precipitation during the analysis period ranged from 22.4 to 49.6 in. in 2012 and 2019, respectively (table 3 ).

Extreme precipitation can be defined as the top 1 percent of precipitating days (Agel and others, 2018, 2019). To determine the top 1 percent of daily precipitation observations, the 100-year period from 1919 through 2019 was used for the Cottonwood Falls and Lebo GHCN stations. The top
1 percent of daily precipitation would be any 24-hour period with precipitation totals greater than or equal to $1.68 \mathrm{in}$. (hereinafter, "extreme precipitation"). During the analysis period, the annual number of days with extreme precipitation ranged from 1 to 7 at the three GHCN stations. The mean was from 2 to 6 days per year of extreme precipitation ranging from 3.9 to 14.9 in. of rain accumulated during those extreme precipitation days (table 3, fig. 2). The percentage of annual precipitation that accumulated during these extreme events ranged from 14 to 36 percent (mean: 24 percent) of the total annual precipitation. A substantial part of the total annual precipitation occurred during these extreme precipitation events over a disproportionately small amount of time when increased runoff and sediment erosion are more likely (fig. 2).

In Kansas, reservoir capacity loss because of sedimentation is dependent on three factors: reservoir age, reservoir volume, and sedimentation rate (deNoyelles and Kastens, 2016). Streambank stabilization has been used as one of the primary ameliorative strategies in an attempt to reduce reservoir sedimentation. Two of the main processes that affect incised-bank streams in this study area are hydraulic erosion by streamflow and gravitational (mass wasting) processes (Simon and others, 2000). Two ways to protect streambanks from these types of erosion are reducing the force of water against the channel bank with various rock structures and (or) planting riparian vegetation to increase resistance to address hydraulic erosion and grading the streambanks to protect against mass wasting (U.S. Army Corps of Engineers, 2002).

Streambank stabilization projects can become costly if all fluvial variables are not considered and can lead to improper implementation that can result in unnecessary loss of streambank and additional costs. The use of process-based models has been determined to be an important tool when evaluating potential streambank stabilization practices (Enlow and others, 2018). When all stream variables were considered in a process-based model and stabilization methods were implemented correctly, some areas (those where riparian vegetation is present in comparison to areas where streambanks are left unprotected) have indicated a decrease in streambank erosion by about three times (Purvis and Fox, 2016). Many factors contribute to the effectiveness of stabilization projects such as riverbank size, scour, streambank material, rate of change in streamflow, remediation type, and degree of vegetation establishment during an erosion event.

The streambank rock structures constructed along the Cottonwood and Neosho Rivers are designed to increase erosion resistance to the streambank toe by slowing water velocities in the near bank region (Watershed Institute, Inc., written commun., 2020). There are, however, no defined streamflow criteria that these structures are built to withstand, and suspended sediment transported during high flows is minimally affected by the rock structures and streambank vegetation (Watershed Institute, Inc., written commun., 2020). Another common ameliorative strategy in this drainage basin is bank grading to address mass wasting of banks. Streambank stabilization project efficiencies for reducing streambank 
Table 3. Annual precipitation totals, extreme event precipitation totals, and counts of extreme precipitation days for Cottonwood Falls, Kansas; Emporia Automated Surface Observing Systems, Kans.; and Lebo, Kans., Global Historical Climatology Network stations (GHCND:USC00141858, GHCND:USW00013989, and GHCND:USC00144608).

[Menne and others, 2012a; National Oceanic and Atmospheric Administration, 2018; in., inch]

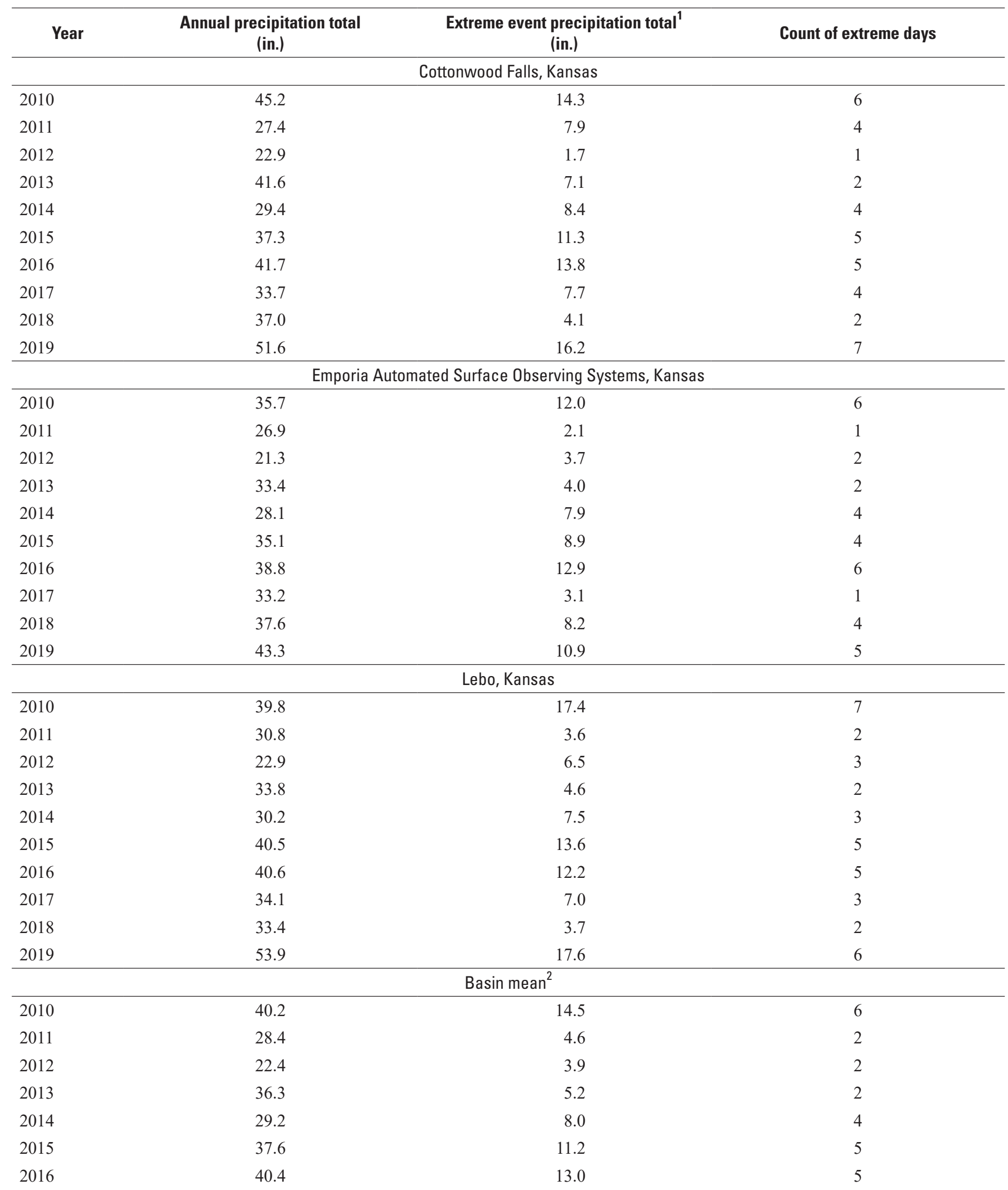


Table 3. Annual precipitation totals, extreme event precipitation totals, and counts of extreme precipitation days for Cottonwood Falls, Kansas; Emporia Automated Surface Observing Systems, Kans.; and Lebo, Kans., Global Historical Climatology Network stations (GHCND:USC00141858, GHCND:USW00013989, and GHCND:USC00144608)._- Continued

[Menne and others, 2012a; National Oceanic and Atmospheric Administration, 2018; in., inch]

\begin{tabular}{lccc}
\hline Year & $\begin{array}{c}\text { Annual precipitation total } \\
\text { (in.) }\end{array}$ & $\begin{array}{c}\text { Extreme event precipitation total } \\
\text { (in.) }\end{array}$ & \begin{tabular}{c} 
Count of extreme days \\
\hline
\end{tabular} \\
\hline 2017 & 33.6 & Basin mean ${ }^{2}$-Continued & 3.9 \\
2018 & 36.0 & 5.3 & 3 \\
2019 & 49.6 & 14.9 & 6 \\
\hline
\end{tabular}

${ }^{1}$ Extreme event is defined as a precipitation event that exceeds the 99 th percentile during the period of analysis over a 24 -hour period (greater than or equal to 1.68 in.).

${ }^{2}$ Defined as the mean of the provided three stations.

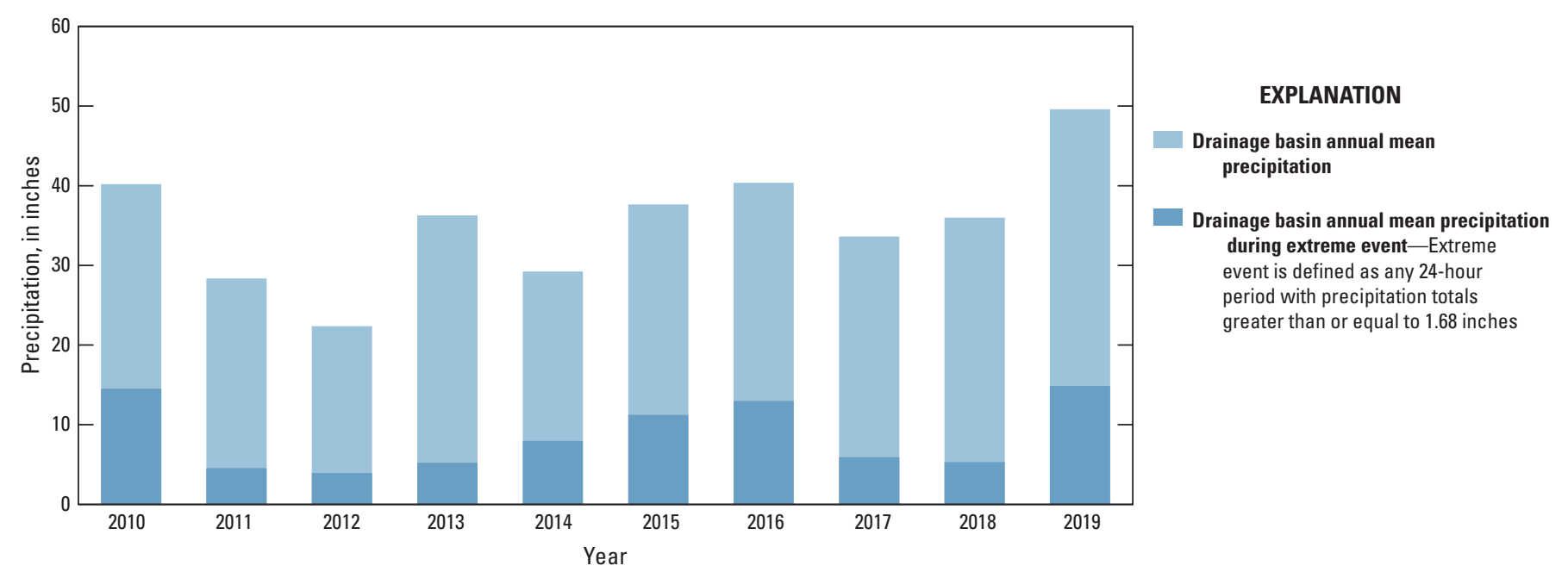

Figure 2. Annual mean precipitation and extreme event precipitation totals for the John Redmond Reservoir drainage basin, Kansas, 2010 through 2019.

erosion are difficult to quantify without accurate and representative data. An assessment using historical aerial imagery compared to postconstruction digital elevation models derived from unmanned aircraft systems flight survey data indicated erosion reduction locally at the stabilized site; however, results varied substantially between different sites (Layzell and Peterson, 2020). This study highlighted the importance of preand postconstruction data collection to accurately quantify the effectiveness of these projects.

\section{Previous Investigations}

Since at least the early 1960s, there has been concern regarding sediment transport and deposition from source to sink in the upper Neosho and Cottonwood River Basins.
Collins (1965) estimated sediment yields and streamflow for Kansas streams. Carswell and Hart (1985) determined the magnitude of streamflow losses and gains during drought conditions in two reaches of the Neosho River. Juracek (2001) analyzed channel stability downstream from John Redmond Reservoir by assessing the pre- and postdam stability of the Neosho River channel. Lee and others (2008) characterized the suspended-sediment load to and from John Redmond Reservoir. Juracek (2010) estimated sedimentation and temporal trends in selected chemical constituents and upstream channel stability for John Redmond Reservoir. Additional studies provided precedent for approaches used in this study (Christensen and others, 2000; Putnam and Pope, 2003; Rasmussen and others, 2005; Lee and others, 2008; Foster and others, 2012; Foster, 2014, 2016). Key findings from studies in the Neosho and Cottonwood River Basins include 
1. Statewide estimates of mean annual sediment yields calculated for large areas across the State indicated that soil erodibility increased from west to east. In the southwestern and south-central parts of the State, the mean annual sediment yield was less than 50 tons, whereas in the northeastern part, it was greater than 5,000 tons (Collins, 1965).

2. Using information from Council Grove Lake and John Redmond Reservoir on the duration of reservoir releases, a streamflow-routing model was developed to estimate water-wave travel times and simulate streamflow transit losses or gains while under drought conditions. Results indicated that severe drought conditions in conjunction with small reservoir-release rates over a long duration had greater total transit losses, larger channel bank storage loss, and larger losses to evapotranspiration. Shorter reservoir-release durations and larger reservoir-release rates resulted in smaller streamflow transit losses overall (Carswell and Hart, 1985).

3. Geomorphic responses were studied for river channels with streamgages $5 \mathrm{mi}$ or less downstream from 24 Federal reservoirs in Kansas. There was a negative trend in channel bed elevation at 15 of 17 streamgages (for which data for the first streamgage downstream from the dam were available), including Marion Reservoir and Council Grove Lake, which was likely related to the composition of the channel bed. Downstream from John Redmond Reservoir at the Burlington site, no trend was indicated. The elevation changes observed in this study are indicative of the spatial and temporal variability associated with streams and rivers that are downstream from reservoirs (Juracek, 2001).

4. Continuous water-quality monitoring using optical turbidity sensors (YSI Incorporated 6600 Extended Deployment System water-quality monitor [hereinafter referred to as "YSI 6600"] model 6136 and opticalbackscatter Hach SOLITAX SC) and ordinary-leastsquares regression equations were used to characterize suspended-sediment loads (in tons) to and from John Redmond Reservoir during February 21, 2007, through February 21, 2008, at three streamgages; two upstream at the Neosho River near Americus (USGS site 07179730) and the Cottonwood site and one downstream at the Burlington site. Streamflow-derived estimates (models developed using historical discrete data) were 7 to 21 times that of turbidity-derived estimates during $2007-8$ at the Burlington site. This is either the result of less sediment being eroded and transported between the reservoir and the streamgage or increased sediment trapping efficiency in the reservoir (Lee and others, 2008).

5. An investigation of sedimentation and deposition of selected chemical constituents in John Redmond Reservoir indicated that the total volume of deposited sediment occupied an estimated 41 percent of the conservation pool during 1964 through 2007 and extrapolated to 2009. This reduced the water-storage capacity of the reservoir at an annual rate of about 1 percent with a mean annual sediment deposition of about 1.24 billion pounds per year $(\mathrm{lb} / \mathrm{yr})$. Channel banks were more likely to be a source of sediment to the reservoir than channel beds. Total phosphorus was determined to be variable over time. Arsenic, chromium, and nickel concentrations detected in the bottom sediments exceeded thresholdeffects guidelines for possible adverse biological effects. Overall trace element concentrations generally were uniform over time in reservoir bottom sediments (Juracek, 2010).

6. Continuous water-quality and streamflow data were coupled with a two-dimensional hydrodynamic model (CE-QUAL-W2) to assess the potential for sediment trapping reduction in John Redmond Reservoir by altering reservoir outflow management. During 2007 through 2010, an estimated 88 percent of sediment transported to John Redmond Reservoir was trapped within the reservoir. The two-dimensional model indicated smaller trapping efficiencies when mean residence times were relatively short and the reservoir was maintained near the normal operating capacity as opposed to higher flood pool levels. The idealized alternative outflow management scenario was projected to reduce sediment trapping in the reservoir by about 3 percent (Lee and Foster, 2013).

7. Linear regression models were previously developed for the Burlingame and Neosho Rapids sites using turbidity and SSC data collected during June 2009 through December 2012 (Foster, 2014). These linear models were used to describe sediment loads during large storm events during May through July 2015. During this period, about 872,000 tons of sediment entered the reservoir although only 57,000 tons of sediment were released, indicating a mean trapping efficiency of 93 percent (Foster, 2016). The computed sediment load reduced reservoir storage in the conservation pool by about 1.6 percent, indicating large infrequent inflows, coupled with minimal releases, can have substantial effects on reservoir storage and lifespan (Foster, 2016).

\section{Methods}

Continuous and discrete water-quality data were collected over a range of streamflow conditions. These data were used to update existing and develop new linear regression models, compute constituent loads and yields, and identify and examine trends during 2010 through 2019. 


\section{Continuous Water-Quality Monitoring}

Continuous (15-minute interval) water-quality and streamflow data were collected at Cottonwood (USGS site 07182250), Burlingame (USGS site 07179750), Neosho Rapids (USGS site 07182390), and Burlington (USGS site 07182510; fig. 1). Streamflow has been measured since 2009 at Burlingame and Neosho Rapids, since 1963 at Cottonwood, and since 1961 at Burlington using standard USGS methods (Sauer and Turnipseed, 2010; Turnipseed and Sauer, 2010; Painter and Loving, 2015). Historical and realtime continuous and discrete water-quality data are available through the USGS National Water Information System database at https://doi.org/10.5066/F7P55KJN (U.S. Geological Survey, 2020).

All study sites were originally equipped with a YSI 6600 monitor that measured water temperature, specific conductance, and turbidity (optical model 6136) (YSI Incorporated, 2012a). The YSI 6600 monitor at Cottonwood was deployed during October 1, 2007, through May 18, 2009; the monitor at Burlingame was deployed during August 1, 2009, through December 16, 2012; the monitor at Neosho Rapids was deployed during August 11, 2009, through November 11, 2015; and the monitor at Burlington was deployed during October 1, 2007, through October 21, 2015 (table 1). The Cottonwood YSI 6600 water-quality monitor was discontinued during 2009 through 2015, the Burlingame monitor was temporarily removed because of extreme drought conditions during 2012 through 2015, and the Burlington monitor was temporarily removed during April 2011 through April 2013 because of extreme drought conditions. The Neosho Rapids water-quality monitor was deployed during the entire analysis period (table 1).

In 2015, the four study sites were equipped with Xylem YSI EXO (model EXO2, hereinafter referred to as "YSI EXO") continuous water-quality monitors that measured the same variables as the YSI 6600 monitors (water temperature, specific conductance, and turbidity; table 1). The Cottonwood YSI EXO water-quality monitor was deployed on April 22, 2015; the Burlingame monitor was deployed on May 2, 2015; the Neosho Rapids monitor was deployed on November 13, 2015; and the Burlington monitor was deployed on October 23, 2015 (table 1). The Burlington water-quality monitor was discontinued on September 30, 2019, whereas the other three monitors were in operation through December 31, 2019. All monitors were installed near the deepest, fastest flowing section of the stream cross section, generally near the centroid, to best represent conditions across the width of the stream and were maintained in accordance with standard USGS procedures (Wagner and others, 2006; Bennett and others, 2014).

Measured water-quality properties were considered comparable between the YSI 6600 and YSI EXO monitor models during the study period except for turbidity. Different turbidity sensors can provide different readings because of differences in the optical properties of the individual sensors (Rasmussen and others, 2009). There are documented differences in the YSI 6600 model 6136 and YSI EXO turbidity sensors (Graham and others, 2018; Stone and others, 2019). Because of these differences, there can be a slight discontinuity in field readings measured with the different sensors, and readings can vary as much as 10 percent at the same site when transitioning; YSI EXO readings generally are lower in value (YSI Incorporated, 2012b). Sensor comparison studies in Kansas have indicated YSI EXO sensor readings to be 6-15 percent less on average than the YSI 6600 model 6136 turbidity sensor readings (Graham and others, 2018; Stone and others, 2019). Because of the differences in sensor readings, data from each sensor were analyzed independently and not combined. Turbidity sensors measure the optical properties of water, which can be affected by suspended and dissolved material such as silt, clay, finely eroded organic material, and microscopic organisms (ASTM International, 2003; Anderson, 2005). Turbidity concentrations experience variability in streams because of fluctuations in streamflow conditions (U.S. Environmental Protection Agency, 2000).

Time-series measurements occasionally were missing or deleted from the dataset because of equipment malfunction, excessive fouling caused by environmental conditions, extreme low- or no-flow conditions, or temporary removal of equipment because of ice. A summary of missing or deleted 15 -minute and daily data is provided in table 4 .

\section{Suspended-Sediment Sample Collection and Analysis}

Suspended-sediment samples were collected over a range of streamflow and turbidity conditions during February 2007 through December 2019 for the Cottonwood site, during February 2007 through September 2019 for the Burlington site, and during August 2009 through December 2019 for the Burlingame and Neosho Rapids sites using primarily depth- and width-integrated sample collection techniques (U.S. Geological Survey, 2006). During ice, extreme cold, or extreme low-flow conditions, samples were collected by other methods including single verticals, multiple verticals, or grab samples (U.S. Geological Survey, 2006). Samples collected using one of these alternative approaches were reviewed and compared to cross-section water-quality field readings measured during the sample and other samples collected during similar conditions to determine if the sample and approach were representative of the mean composition of the stream cross section. If a sample was determined to not be representative of the cross section, it was excluded from the dataset.

All samples were analyzed for total SSC, sand-fine split percentage, and in most cases of high turbidity (greater than or equal to $500 \mathrm{FNU}$ ), five-point grain size analysis by the USGS Iowa Sediment Laboratory in Iowa City, Iowa, according to methods described in Guy (1969). 
Table 4. Summary statistics for variables measured or computed continuously at Cottonwood River near Plymouth, Kansas (U.S. Geological Survey [USGS] site 07182250); Neosho River at Burlingame Road near Emporia, Kans. (USGS site 07179750); Neosho River at Neosho Rapids, Kans. (USGS site 07182390); and Neosho River at Burlington, Kans. (USGS site 07182510), during 2010 through 2019.

[Continuous real-time water-quality data are available on the U.S. Geological Survey National Real-Time Water Quality website (https://nrtwq.usgs.gov/ks). Summary statistics were calculated using 15 -minute continuous water-quality data summarized into daily mean values. $n$, number of measurements; $\mathrm{ft}^{3} / \mathrm{s}$, cubic foot per second; ${ }^{\circ} \mathrm{C}$, degree Celsius; $\mu \mathrm{S} / \mathrm{cm}$, microsiemens per centimeter at 25 degrees Celsius; EXO, Xylem YSI EXO, model EXO2, continuous water-quality monitor; FNU, formazin nephelometric unit; <, less than; 6136, YSI Incorporated 6600 Extended Deployment System water-quality monitor model 6136]

\begin{tabular}{|c|c|c|c|c|c|c|}
\hline Continuous variable & $n$ & Minimum & Maximum & Mean & Median & $\begin{array}{c}\text { Percent } \\
\text { missing } \\
\text { data }\end{array}$ \\
\hline \multicolumn{7}{|c|}{ Cottonwood River near Plymouth, Kansas } \\
\hline \multicolumn{7}{|c|}{ 15-minute measurements } \\
\hline Streamflow $\left(\mathrm{ft}^{3} / \mathrm{s}\right)$ & 337,570 & 14.8 & 34,700 & 785 & 187 & 3.8 \\
\hline Water temperature $\left({ }^{\circ} \mathrm{C}\right)$ & 155,286 & -0.1 & 33 & 17 & 17 & 56 \\
\hline Turbidity (EXO, FNU) & 150,136 & $<1.0$ & 1,640 & 60 & 25 & 9 \\
\hline \multicolumn{7}{|c|}{ Daily mean measurements } \\
\hline $\begin{array}{l}\text { 1963-2019 historical daily streamflow } \\
\left(\mathrm{ft}^{3} / \mathrm{s}\right)\end{array}$ & 20,759 & 8.7 & 73,500 & 861 & 246 & 1 \\
\hline Turbidity (EXO, FNU) & 1,585 & 2.3 & 822 & 61 & 26 & 8 \\
\hline \multicolumn{7}{|c|}{ Neosho River at Burlingame Road near Emporia, Kansas } \\
\hline \multicolumn{7}{|c|}{ 15-minute measurements } \\
\hline Streamflow $\left(\mathrm{ft}^{3} / \mathrm{s}\right)$ & 339,622 & 0.5 & 17,400 & 339 & 32 & 3 \\
\hline Water temperature $\left({ }^{\circ} \mathrm{C}\right)$ & 243,214 & -0.1 & 38 & 16 & 17 & 31 \\
\hline Specific conductance $(\mu \mathrm{S} / \mathrm{cm})$ & 236,684 & 111 & 699 & 433 & 436 & 33 \\
\hline Turbidity $(6136$, FNU) & 86,365 & $<1.0$ & 2,450 & 53 & 23 & 54 \\
\hline Turbidity (EXO, FNU) & 138,735 & 2.3 & 2,300 & 51 & 20 & 15 \\
\hline \multicolumn{7}{|c|}{ Daily mean measurements } \\
\hline Turbidity (EXO, FNU) & 1,493 & 2.6 & 838 & 51 & 20 & 12 \\
\hline \multicolumn{7}{|c|}{ Neosho River at Neosho Rapids, Kansas } \\
\hline \multicolumn{7}{|c|}{ 15-minute measurements } \\
\hline Streamflow $\left(\mathrm{ft}^{3} / \mathrm{s}\right)$ & 96,661 & 12.9 & 34,100 & 1,790 & 303 & 72 \\
\hline Water temperature $\left({ }^{\circ} \mathrm{C}\right)$ & 308,737 & -0.3 & 38 & 16 & 16 & 12 \\
\hline Specific conductance $(\mu \mathrm{S} / \mathrm{cm})$ & 279,241 & 66 & 1,160 & 623 & 633 & 20 \\
\hline Turbidity $(6136$, FNU) & 153,685 & 1.7 & 1,460 & 68 & 31 & 25 \\
\hline Turbidity (EXO, FNU) & 121,810 & 1.8 & 1,190 & 77 & 27 & 16 \\
\hline
\end{tabular}


Table 4. Summary statistics for variables measured or computed continuously at Cottonwood River near Plymouth, Kansas (U.S. Geological Survey [USGS] site 07182250); Neosho River at Burlingame Road near Emporia, Kans. (USGS site 07179750); Neosho River at Neosho Rapids, Kans. (USGS site 07182390); and Neosho River at Burlington, Kans. (USGS site 07182510), during 2010 through 2019.-Continued

[Continuous real-time water-quality data are available on the U.S. Geological Survey National Real-Time Water Quality website (https://nrtwq.usgs.gov/ks). Summary statistics were calculated using 15 -minute continuous water-quality data summarized into daily mean values. $n$, number of measurements; $\mathrm{ft}^{3} / \mathrm{s}$, cubic foot per second; ${ }^{\circ} \mathrm{C}$, degree Celsius; $\mu \mathrm{S} / \mathrm{cm}$, microsiemens per centimeter at 25 degrees Celsius; EXO, Xylem YSI EXO, model EXO2, continuous water-quality monitor; FNU, formazin nephelometric unit; <, less than; 6136, YSI Incorporated 6600 Extended Deployment System water-quality monitor model 6136]

\begin{tabular}{|c|c|c|c|c|c|c|}
\hline Continuous variable & $n$ & Minimum & Maximum & Mean & Median & $\begin{array}{c}\text { Percent } \\
\text { missing } \\
\text { data }\end{array}$ \\
\hline \multicolumn{7}{|c|}{ Neosho River at Neosho Rapids, Kansas-Continued } \\
\hline \multicolumn{7}{|c|}{ Daily mean measurements } \\
\hline $\begin{array}{l}\text { 2009-19 historical daily streamflow } \\
\left(\mathrm{ft}^{3} / \mathrm{s}\right)\end{array}$ & 3,542 & 15.5 & 33,200 & 1,220 & 269 & 7 \\
\hline Water temperature $\left({ }^{\circ} \mathrm{C}\right)$ & 3,353 & -0.1 & 32 & 16 & 16 & 8 \\
\hline Specific conductance $(\mu \mathrm{S} / \mathrm{cm})$ & 3,076 & 161 & 1,080 & 623 & 632 & 16 \\
\hline Turbidity (6136, FNU) & 1,822 & 2.0 & 1,030 & 69 & 31 & 15 \\
\hline Turbidity (EXO, FNU) & 1,281 & 1.9 & 877 & 79 & 28 & 15 \\
\hline Water temperature $\left({ }^{\circ} \mathrm{C}\right)$ & 266,425 & -0.8 & 33 & 15 & 16 & 24 \\
\hline Specific conductance $(\mu \mathrm{S} / \mathrm{cm})$ & 257,859 & 190 & 729 & 485 & 489 & 27 \\
\hline Turbidity (6136, FNU) & 114,980 & 3.9 & 760 & 29 & 19 & 44 \\
\hline Turbidity (EXO, FNU) & 126,702 & 3.3 & 1,640 & 28 & 23 & 14 \\
\hline \multicolumn{7}{|c|}{ Daily mean measurements } \\
\hline $\begin{array}{l}\text { 1961-2019 historical daily streamflow } \\
\left(\mathrm{ft}^{3} / \mathrm{s}\right)\end{array}$ & 21,368 & 0.86 & 34,600 & 1,170 & 374 & 0 \\
\hline Streamflow $\left(\mathrm{ft}^{3} / \mathrm{s}\right)$ & 3,652 & 7.6 & 34,600 & 1,510 & 233 & 0 \\
\hline Water temperature $\left({ }^{\circ} \mathrm{C}\right)$ & 2,780 & 0.0 & 32 & 16 & 16 & 24 \\
\hline
\end{tabular}

\section{Quality Control}

Concurrent discrete replicate samples were collected for quality-control purposes to identify, quantify, and document potential bias and variability in data that resulted from the collection, processing, and analysis of samples in accordance with USGS standardized sampling techniques (U.S. Geological Survey, 2006). About 10 percent of discrete SSC samples collected at all sites throughout this study were replicate samples. For replicate samples collected during the analysis period, the relative percentage difference (RPD) was calculated by dividing the difference between the sample and replicate by the mean of the two results. RPD values ranged from about 0 to 44 percent and averaged about 10 percent (table 5). Cottonwood had the largest mean RPD among replicate samples (19 percent); however, samples with the largest RPD were typically storm samples when rapidly changing conditions frequently occurred. Larger RPDs could be attributed to changing streamflow conditions, poor mixing of suspended sediment in the water column, sampling techniques, or potential analysis error.

During sample collection, turbidity values were measured at every sample point across the width of the stream cross section and compared to concomitant in situ continuous turbidity sensor measurements. Comparisons between field-measured cross-sectional means and continuous turbidity measurements for YSI 6600 model 6136 and YSI EXO turbidity sensors had a near 1:1 relation in slopes (coefficient of determination 
Table 5. Summary of quality-control replicate results for discretely collected suspended-sediment concentration replicate data, 2010 through 2019.

[Suspended-sediment concentration data were analyzed by the U.S. Geological Survey (USGS) Iowa Sediment Laboratory; QC, quality control; pcode, parameter code; RPD, relative percentage difference; <, less than]

\begin{tabular}{lcccc}
\hline $\begin{array}{c}\text { OC summary statistics for } \\
\text { suspended-sediment } \\
\text { concentration } \\
\text { (USGS pcode 80154) }\end{array}$ & $\begin{array}{c}\text { Cottonwood River near } \\
\text { Plymouth, Kansas } \\
\text { (USGS site 07182250) }\end{array}$ & $\begin{array}{c}\text { Neosho River at } \\
\text { Burlingame Road near } \\
\text { Emporia, Kansas } \\
\text { (USGS site 07179750) }\end{array}$ & $\begin{array}{c}\text { Neosho River at } \\
\text { Neosho Rapids, Kansas } \\
\text { (USGS site 07182390) }\end{array}$ & $\begin{array}{c}\text { Neosho River at } \\
\text { Burlington, Kansas } \\
\text { (USGS site 07182510) }\end{array}$ \\
\hline Total number of replicate pairs & 5 & 4 & 3 & 5 \\
Minimum RPD & 0.6 & 1.1 & 0.2 & $<1.0$ \\
Maximum RPD & 44.1 & 8.7 & 7.4 & 35.7 \\
Mean RPD & 19 & 5.4 & 3.7 & 9.6 \\
Median RPD & 13.8 & 5.9 & 3.5 & 2.2 \\
\hline
\end{tabular}

$\left[R^{2}\right]=0.96$ to 0.99 ; fig. 3 , fig. 4). Samples with turbidity measurements that plotted outside the 1:1 relation were likely due to localized differences in turbidity in the stream cross section.

Water temperature and specific conductance sensor ranges were not exceeded during the analysis period ( -5 to 50 plus or minus $[ \pm] 2$ degrees Celsius $\left[{ }^{\circ} \mathrm{C}\right]$ for water temperature and 0 to 100,000 microsiemens per centimeter $[\mu \mathrm{S} / \mathrm{cm}] \pm$ 1 percent or $2 \mu \mathrm{S} / \mathrm{cm}$, whichever is greater, for specific conductance; YSI Incorporated, 2015). The YSI 6600 model 6136 optical turbidity sensor operational limit is 1,000 FNU, and the YSI EXO turbidity sensor operational limit is 4,000 FNU (YSI Incorporated, 2007, 2019). The YSI 6600 model 6136 turbidity sensor operational limit was exceeded less than 1 percent of the time at the Burlingame and Neosho Rapids sites and was never exceeded at Burlington. The YSI EXO turbidity sensor operational limit was never exceeded at any site during the analysis period.

\section{Development of Linear Regression Models}

Models for total suspended sediment were updated using data collected through March 2019. Previously published models used turbidity from YSI 6600 model 6136 optical turbidity sensors as a surrogate for SSC (table 6; Foster, 2014). These models were updated with data through the end of the deployment of the YSI 6600 model 6136 turbidity sensors, and new models were developed during the period of deployment of the YSI EXO turbidity sensors. Separate models were developed for the individual sensors during their respective periods of deployment to account for the known differences between turbidity sensors and to avoid additional bias in the SSC surrogate models.

Discrete water-quality samples were collected over a range of streamflow conditions to develop robust regression models that adequately represent conditions at each site. Models were developed using ordinary-least-squares regression analysis to relate SSC to concomitant continuously measured streamflow and instream turbidity (Rasmussen and others, 2009; Helsel and others, 2020). Concomitant continuously measured streamflow or turbidity values were time interpolated to the collection time of the associated sample. If concomitant continuous data were not available ( 2 or more hours of values bracketing the sample collection time were missing) because of fouling, changes in equipment, or unsuitable site conditions, the field monitor value measured during sampling was substituted.

Before developing regression models, all discrete suspended-sediment samples were analyzed for potential outliers (Rasmussen and others, 2009). Samples were not included in the dataset if the sample was affected by ice, the sample bottle was broken during shipment to the analyzing laboratory, or there were no available concomitant water-quality data associated with the sample. Regression models were evaluated using statistical significance $\left(R^{2}\right.$, root mean square error, model standard percentage error [MSPE]) along with variance and distribution of discrete SSC and continuous turbidity data (Rasmussen and others, 2009; Foster, 2014; Helsel and others, 2020). For each site, a streamflow-only based model was developed to compute concentrations and loads during periods when concomitant water-quality physical properties were unavailable.

Updated models are useful for evaluating SSC to compare with water-quality criteria and for computing loads and yields to assess constituent transport through the drainage basin. The water-quality information quantifies and characterizes sediment transported into and out of the reservoir. Details of developed regression models for this report are included in appendixes 1 through 12 .

\section{Suspended-Sediment Concentrations, Loads, and Yields and Streamflow}

Continuously measured turbidity and streamflow data provide accurate and reliable computations of suspendedsediment concentrations, loads, and yields (Christensen and others, 2000; Putnam and Pope, 2003; Rasmussen and others, 

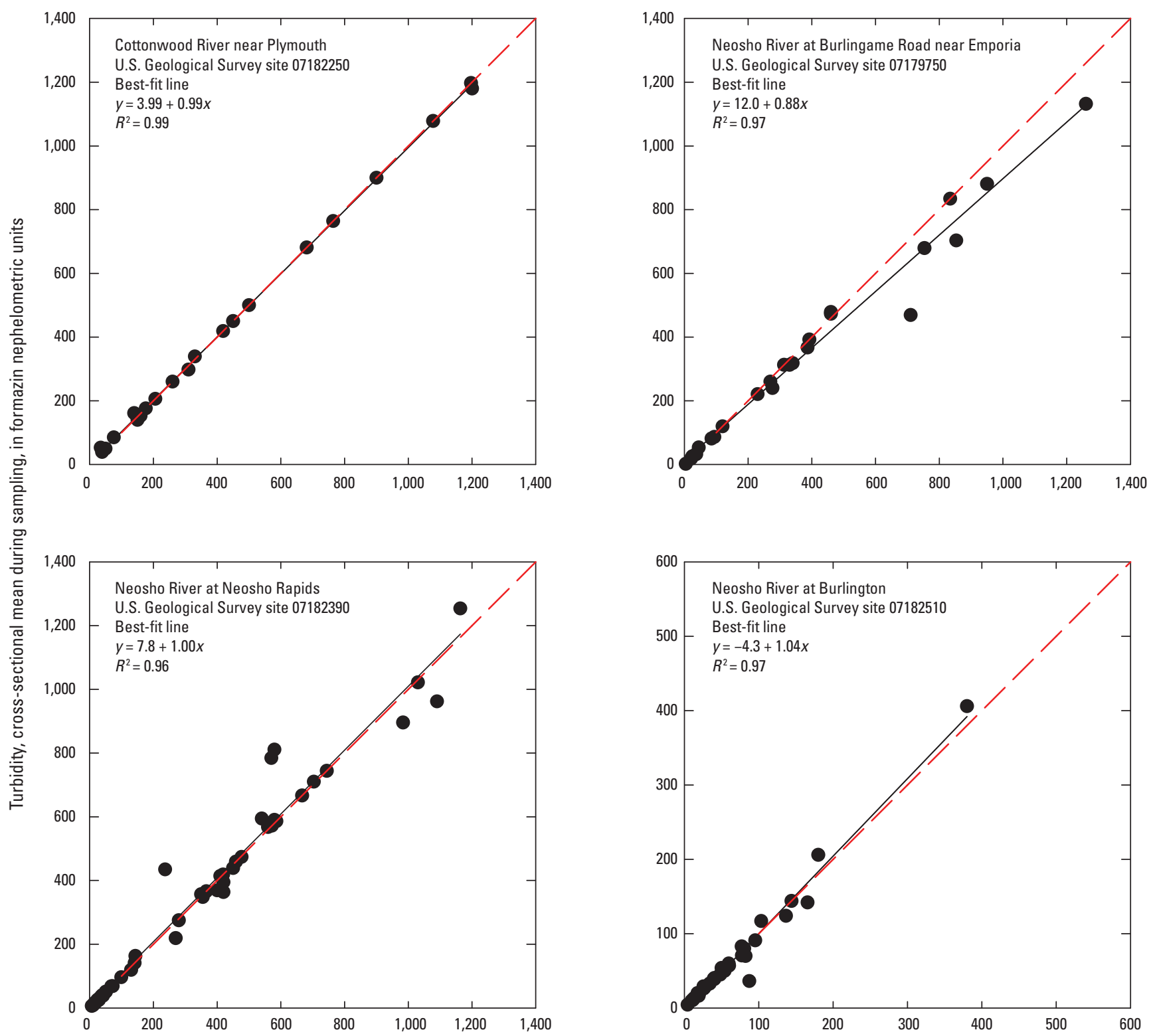

Turbidity, continuously measured, in formazin nephelometric units

\section{EXPLANATION}

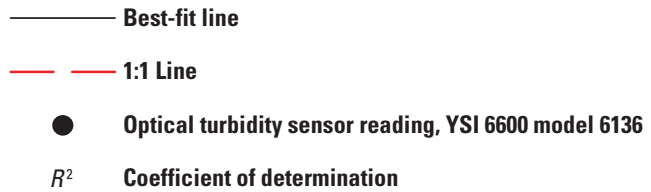

Figure 3. YSI Incorporated 6600 Extended Deployment System (YSI 6600 model 6136) turbidity sensor relation between continuously measured values and cross-sectional means during discrete sample collection for sites on the Cottonwood and Neosho Rivers, Kansas. 

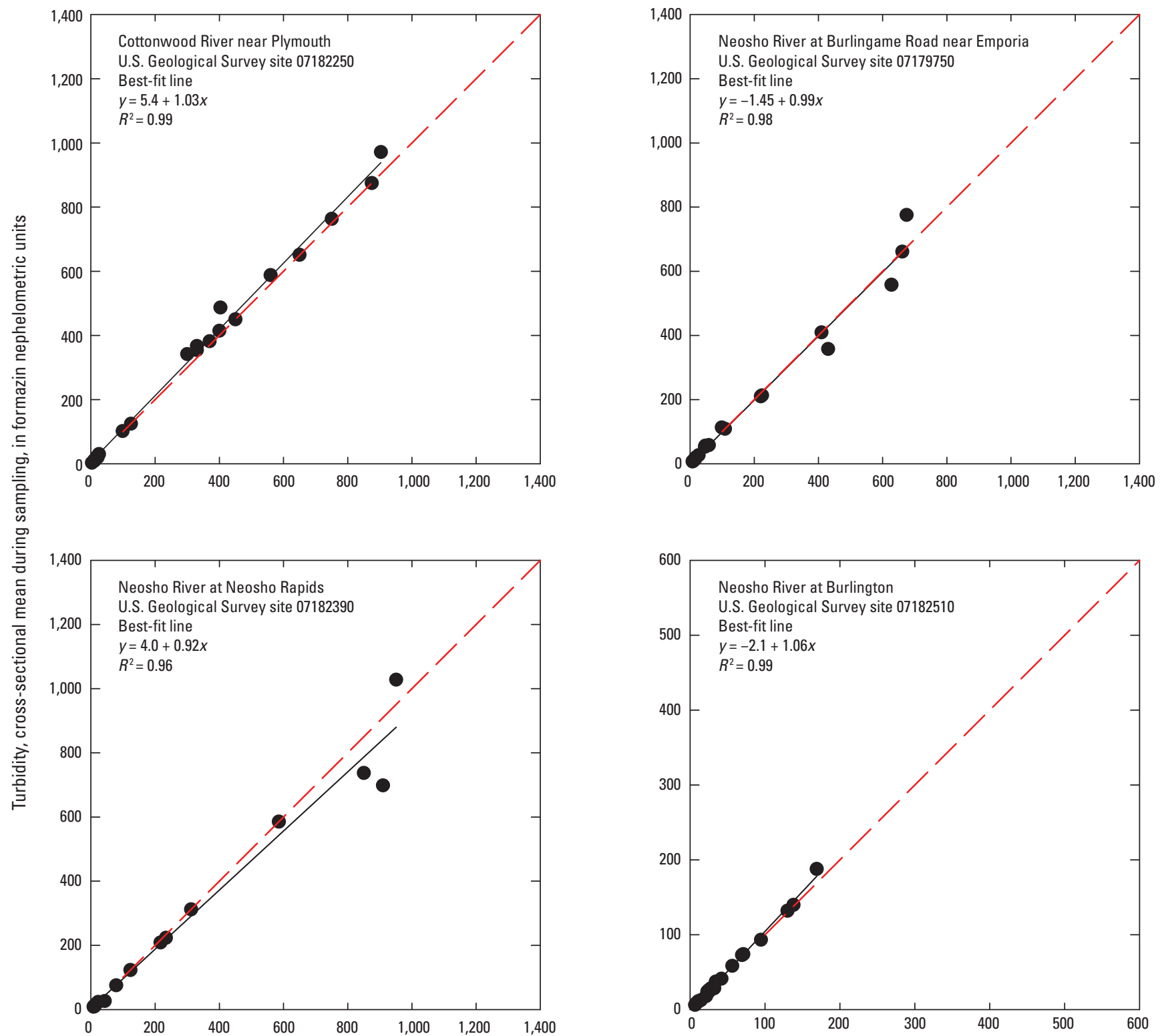

Turbidity, continuously measured, in formazin nephelometric units

\section{EXPLANATION}

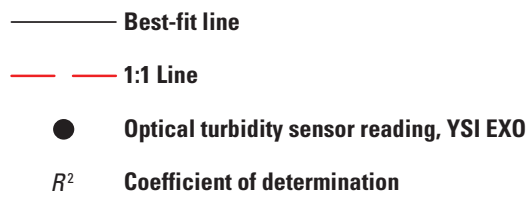

Figure 4. Xylem YSI EXO (YSI EXO), turbidity sensor relation between continuously measured values and cross-sectional means during discrete sample collection for sites on the Cottonwood and Neosho Rivers, Kansas. 
Table 6. Developed regression models (Foster, 2014) and updated regression models and summary statistics for continuous suspended-sediment concentration computations (in milligrams per liter) for Cottonwood River near Plymouth, Kansas (U.S. Geological Survey [USGS] site 07182250); Neosho River at Burlingame Road near Emporia, Kans. (USGS site 07179750); Neosho River at Neosho Rapids, Kans. (USGS site 07182390); and Neosho River at Burlington, Kans. (USGS site 07182510).

$\left[R^{2}\right.$, coefficient of determination; MSPE, model standard percentage error; RMSE, root mean square error; $n$, number of discrete samples; log, logarithm base 10; SSC, suspended-sediment concentration, in milligrams per liter; turb, turbidity from sensors reported in Foster (2014); --, data not available; $Q$, streamflow, in cubic feet per second; turb ${ }_{6136}$, turbidity from YSI Incorporated 6600 Extended Deployment System water-quality monitor model 6136 turbidity sensor, in formazin nephelometric units; App., Appendix; turb ${ }_{E X O}$, turbidity from Xylem YSI EXO turbidity sensor, in formazin nephelometric units]

\begin{tabular}{|c|c|c|c|c|c|c|c|c|c|c|c|c|}
\hline \multirow[b]{2}{*}{ Regression model } & \multirow[b]{2}{*}{$\begin{array}{c}\text { Model } \\
\text { archive } \\
\text { summary }\end{array}$} & \multirow[b]{2}{*}{$\begin{array}{l}\text { Period of } \\
\text { application }\end{array}$} & \multirow[b]{2}{*}{$\begin{array}{l}\text { Multiple } \\
R^{2}\end{array}$} & \multirow[b]{2}{*}{$\begin{array}{l}\text { Adjusted } \\
R^{2}\end{array}$} & \multirow[b]{2}{*}{ MSPE } & \multirow[b]{2}{*}{ RMSE } & \multirow{2}{*}{$\begin{array}{c}\text { Bias } \\
\text { correction } \\
\text { factor } \\
\text { (Duan, } \\
\text { 1983) }\end{array}$} & \multicolumn{5}{|c|}{ Discrete data } \\
\hline & & & & & & & & $\mathbf{n}$ & $\begin{array}{l}\text { Range of values } \\
\text { in variable } \\
\text { measurements }\end{array}$ & Mean & Median & $\begin{array}{l}\text { Standard } \\
\text { deviation }\end{array}$ \\
\hline \multicolumn{13}{|c|}{ Cottonwood River near Plymouth, Kansas } \\
\hline \multicolumn{13}{|c|}{ Foster (2014) } \\
\hline \multirow[t]{2}{*}{$\log (S S C)=1.02 \log ($ turb $)+0.30$} & -- & -- & 0.97 & 0.97 & -- & 0.1 & 1.02 & 29 & turb: $17-1,050$ & 374 & 340 & 310 \\
\hline & & & & & & & & & SSC: $30-2,140$ & 875 & 784 & 719 \\
\hline $\log (S S C)=0.742 \log (Q)+0.21$ & -- & -- & 0.6 & 0.59 & -- & 0.38 & 1.33 & 29 & $Q: 47-102,000$ & 6,450 & 2,940 & 18,600 \\
\hline \multicolumn{13}{|c|}{ Updated } \\
\hline \multirow[t]{2}{*}{$\log (S S C)=0.931 \log \left(\right.$ turb $\left._{6136}\right)+0.547$} & App. 1 & $10 / 1 / 2007-5 / 18 / 2009$ & 0.95 & 0.95 & 24.5 & 0.105 & 1.03 & 22 & $\operatorname{turb}_{6136}: 35-1,200$ & 421 & 285 & 373 \\
\hline & & & & & & & & & SSC: $78-3,500$ & 968 & 746 & 839 \\
\hline \multirow[t]{2}{*}{$\log (S S C)=1.04 \log \left(\right.$ turb $\left._{E X O}\right)+0.371$} & App. 5 & $4 / 22 / 2015-12 / 31 / 2019$ & 0.96 & 0.96 & 34.1 & 0.145 & 1.06 & 23 & ${ }^{t u r b}{ }_{E X O}: 11-903$ & 355 & 333 & 289 \\
\hline & & & & & & & & & SSC: $18-3,480$ & 1,130 & 987 & 1,030 \\
\hline \multirow[t]{2}{*}{$\log (S S C)=0.617 \log (Q)+0.732$} & App. 9 & ${ }^{1} 1 / 1 / 2010-12 / 31 / 2019$ & 0.64 & 0.63 & 95.5 & 0.369 & 1.36 & 47 & $Q: 48-22,400$ & 5,700 & 3,700 & 6,110 \\
\hline & & & & & & & & & SSC: $18-3,960$ & 1,150 & 828 & 1,060 \\
\hline \multicolumn{13}{|c|}{ Neosho River at Burlingame Road near Emporia, Kansas } \\
\hline \multicolumn{13}{|c|}{ Foster (2014) } \\
\hline \multirow[t]{2}{*}{$\log (S S C)=1.07 \log ($ turb $)+0.11$} & -- & -- & 0.95 & 0.95 & -- & 0.17 & 1.07 & 27 & turb: $2.2-1,130$ & 343 & 310 & 309 \\
\hline & & & & & & & & & SSC: $4.0-2,240$ & 747 & 567 & 738 \\
\hline $\log (S S C)=0.744 \log (Q)+0.50$ & -- & -- & 0.54 & 0.52 & -- & 0.50 & 2.04 & 27 & $Q: 18-5,320$ & 1,300 & 448 & 1,480 \\
\hline \multicolumn{13}{|c|}{ Updated } \\
\hline \multirow{2}{*}{$\begin{array}{l}\log (S S C)=1.10 \log \left(\text { turb }_{6136}\right) \\
\quad+0.00834\end{array}$} & App. 2 & 8/1/2009-12/16/2012 & 0.95 & 0.94 & 41.2 & 0.174 & 1.08 & 27 & $\operatorname{turb}_{6136}: 4.3-1,260$ & 371 & 313 & 336 \\
\hline & & & & & & & & & SSC: $4.0-2,240$ & 747 & 567 & 724 \\
\hline \multirow[t]{2}{*}{$\log (S S C)=1.12 \log \left(\right.$ turb $\left._{E X O}\right)+0.0799$} & App. 6 & $5 / 2 / 2015-12 / 31 / 2019$ & 0.99 & 0.99 & 20.7 & 0.09 & 1.02 & 23 & turb $_{E X O}: 7.9-965$ & 286 & 109 & 302 \\
\hline & & & & & & & & & SSC: $11-2,730$ & 721 & 274 & 844 \\
\hline \multirow[t]{2}{*}{$\log (S S C)=0.707 \log (Q)+0.533$} & App. 10 & ${ }^{1} 1 / 1 / 2010-12 / 31 / 2019$ & 0.78 & 0.77 & 93.8 & 0.364 & 1.32 & 47 & $Q: 2.5-11,100$ & 1,860 & 978 & 2,410 \\
\hline & & & & & & & & & SSC: $0.6-2,730$ & 730 & 438 & 792 \\
\hline
\end{tabular}


Table 6. Developed regression models (Foster, 2014) and updated regression models and summary statistics for continuous suspended-sediment concentration computations (in milligrams per liter) for Cottonwood River near Plymouth, Kansas (U.S. Geological Survey [USGS] site 07182250); Neosho River at Burlingame Road near Emporia, Kans. (USGS site 07179750); Neosho River at Neosho Rapids, Kans. (USGS site 07182390); and Neosho River at Burlington, Kans. (USGS site 07182510).-Continued

$\left[R^{2}\right.$, coefficient of determination; MSPE, model standard percentage error; RMSE, root mean square error; $n$, number of discrete samples; log, logarithm base 10; SSC, suspended-sediment concentration, in milligrams per liter; turb, turbidity from sensors reported in Foster (2014); --, data not available; $Q$, streamflow, in cubic feet per second; turb ${ }_{6136}$, turbidity from YSI Incorporated 6600 Extended Deployment System water-quality monitor model 6136 turbidity sensor, in formazin nephelometric units; App., Appendix; turb $E_{E O}$, turbidity from Xylem YSI EXO turbidity sensor, in formazin nephelometric units]

\begin{tabular}{|c|c|c|c|c|c|c|c|c|c|c|c|c|}
\hline \multirow[b]{2}{*}{ Regression model } & \multirow[b]{2}{*}{$\begin{array}{c}\text { Model } \\
\text { archive } \\
\text { summary }\end{array}$} & \multirow[b]{2}{*}{$\begin{array}{l}\text { Period of } \\
\text { application }\end{array}$} & \multirow[b]{2}{*}{$\begin{array}{c}\text { Multiple } \\
R^{2}\end{array}$} & \multirow[b]{2}{*}{$\begin{array}{c}\text { Adjusted } \\
R^{2}\end{array}$} & \multirow[b]{2}{*}{ MSPE } & \multirow[b]{2}{*}{ RMSE } & \multirow{2}{*}{$\begin{array}{c}\text { Bias } \\
\text { correction } \\
\text { factor } \\
\text { (Duan, } \\
\text { 1983) }\end{array}$} & \multicolumn{5}{|c|}{ Discrete data } \\
\hline & & & & & & & & $n$ & $\begin{array}{c}\text { Range of values } \\
\text { in variable } \\
\text { measurements }\end{array}$ & Mean & Median & $\begin{array}{l}\text { Standard } \\
\text { deviation }\end{array}$ \\
\hline \multicolumn{13}{|c|}{ Neosho River at Neosho Rapids, Kansas } \\
\hline \multicolumn{13}{|c|}{ Foster (2014) } \\
\hline \multirow[t]{2}{*}{$\log (S S C)=1.06 \log ($ turb $)+0.17$} & -- & -- & 0.97 & 0.97 & -- & 0.11 & 1.03 & 28 & turb: $17-1,020$ & 412 & 400 & 324 \\
\hline & & & & & & & & & SSC: $27-2,420$ & 939 & 883 & 781 \\
\hline $\log (S S C)=0.700 \log (Q)+0.32$ & -- & -- & 0.53 & 0.51 & -- & 0.44 & 1.54 & 28 & $Q: 49-24,900$ & 5,450 & 2,550 & 6,580 \\
\hline \multicolumn{13}{|c|}{ Updated } \\
\hline \multirow[t]{2}{*}{$\log (S S C)=1.07 \log \left(\right.$ turb $\left._{6136}\right)+0.16$} & App. 3 & $8 / 11 / 2009-11 / 11 / 2015$ & 0.96 & 0.96 & 32.1 & 0.137 & 1.05 & 42 & $\operatorname{turb}_{6136}: 6.6-1,160$ & 374 & 378 & 320 \\
\hline & & & & & & & & & $S S C: 14-4,230$ & 911 & 707 & 886 \\
\hline \multirow[t]{2}{*}{$\log (S S C)=1.13 \log \left(\right.$ turb $\left._{E X O}\right)+0.105$} & App. 7 & $11 / 13 / 2015-12 / 31 / 2019$ & 0.99 & 0.99 & 21.6 & 0.093 & 1.02 & 17 & turb $_{E X O}: 8.3-951$ & 343 & 217 & 339 \\
\hline & & & & & & & & & $S S C: 17-3,570$ & 1020 & 515 & 1,090 \\
\hline \multirow[t]{2}{*}{$\log (S S C)=0.799 \log (Q)-0.0546$} & App. 11 & ${ }^{1} 1 / 1 / 2010-12 / 31 / 2019$ & 0.71 & 0.70 & 108 & 0.407 & 1.43 & 56 & $Q: 48.8-30,400$ & 5,570 & 2,490 & 6,500 \\
\hline & & & & & & & & & SSC: $14-4,230$ & 953 & 647 & 971 \\
\hline \multicolumn{13}{|c|}{ Neosho River at Burlington, Kansas } \\
\hline \multicolumn{13}{|c|}{ Updated } \\
\hline \multirow[t]{2}{*}{$\log (S S C)=0.904 \log \left(\right.$ turb $\left._{6136}\right)+0.316$} & App. 4 & $10 / 1 / 2007-10 / 21 / 2015$ & 0.93 & 0.93 & 23.1 & 0.0995 & 1.03 & 34 & $\operatorname{turb}_{6136}: 4.3-380$ & 68 & 49 & 70 \\
\hline & & & & & & & & & $S S C: 12-582$ & 97 & 70 & 106 \\
\hline \multirow[t]{2}{*}{$\log (S S C)=0.896 \log \left(t u r b_{E X O}\right)+0.382$} & App. 8 & $10 / 23 / 2015-9 / 30 / 2019$ & 0.93 & 0.92 & 25.2 & 0.108 & 1.03 & 18 & turb $_{E X O}: 6.6-169$ & 48 & 27 & 44 \\
\hline & & & & & & & & & SSC: $11-335$ & 78 & 48 & 75 \\
\hline \multirow[t]{2}{*}{$\log (S S C)=0.333 \log (Q)+0.806$} & App. 12 & ${ }^{1} 1 / 1 / 2010-12 / 31 / 2019$ & 0.46 & 0.45 & 70.2 & 0.284 & 1.25 & 52 & $Q: 31.2-12,500$ & 2,530 & 1,420 & 2,940 \\
\hline & & & & & & & & & $S S C: 11-582$ & 90 & 61 & 97 \\
\hline
\end{tabular}

${ }^{1}$ Flow-based models $(Q)$ are considered secondary models and were only used when primary model data (continuous water-quality data) were missing for concentration and load computation. 
2005; Lee and others, 2008; Rasmussen and others, 2008). When 15-minute or hourly streamflow data were missing, daily values were estimated, reviewed, and approved following USGS methods (Turnipseed and Sauer, 2010; Painter and Loving, 2015). When continuous water-quality data were missing because of periods of extreme weather or waterquality monitor malfunction or during routine maintenance visits, daily mean values were computed by averaging hourly values and were reviewed and approved according to USGS methods (Wagner and others, 2006; U.S. Geological Survey, 2008; Bennett and others, 2014). Daily mean values (rather than 15-minute or hourly data) were used for concentration and load computation because of missing continuous streamflow data and periods of missing continuous water-quality data. Limitations of this approach include loss of intraday variability, which affects computed concentrations and thus computed loads.

When daily turbidity data were unavailable, a streamflow-based model was substituted as a secondary means of computation and provided computed SSC values. The streamflow-based SSC values were shifted to align with the next available turbidity-based SSC values based on methods described in Porterfield (1972) to align computed concentrations among model types.

Suspended-sediment concentrations and loads were calculated from January 1, 2010, through December 31, 2019, except during extended periods with missing turbidity daily values. Large gaps in water-quality data limited the ability to continuously compute suspended-sediment concentrations and loads at sites (table 1). Although the streamflow-based regression model was considered a suitable substitute for shorter periods of missing data, longer durations of missing days introduce greater uncertainty into the final concentration, load, and yield computations. Computed concentration, load, and yield data are unavailable at the Cottonwood, Burlingame, and Burlington sites for long periods of time when water-quality data were not collected. The monitor was discontinued at Burlington in 2019 at the end of September, and only streamflow data were available for concentration and load estimations for the remaining 95 days. For this period of missing turbidity data, the streamflow-based model was considered a suitable substitute, and the level of uncertainty introduced was considered minimal because of minor fluctuations in streamflow and lack of large precipitation events during the period.

Daily loads were calculated by multiplying computed daily SSC (in milligrams per liter) by daily streamflow (in cubic feet per second) and a unit conversion factor $(0.0027$ to calculate the load in tons per day). Annual sediment loads were estimated by summing the daily loads. Annual yields (in pounds per square mile) were calculated by dividing annual loads by the contributing drainage area (table 2). Sediment yields were computed to compare the four sites. Computed suspended-sediment concentrations, loads, and yields do not account for the ungaged 9 percent of the drainage basin. Previous studies have used different estimation methods for the ungaged part of the drainage basin, but these methods have undefined error associated with the estimates (Lee and others, 2008; Foster, 2016). The computed suspended-sediment concentrations, loads, and yields described in this report only account for the gaged 91 percent of the drainage basin.

\section{Suspended Sediment Transported during High-Flow Events}

Streambank stabilization effectiveness is difficult to assess on a drainage basin scale. During high-flow events, water can breach channel banks, resulting in erosion of lands, damage to nearby property, and subsequent destruction to the streambank stabilization project, thus reducing their effectiveness at minimizing erosion. Determining bankfull flow, or maximum streamflow without overflowing onto the floodplain, is an important step in the planning process for streambank stabilization (Baird and others, 2015). Suspended-sediment loads transported during high-flow events (greater than channel-controlled flow) were computed and compared to the total suspended-sediment load during the analysis period.

National Weather Service (NWS) flood action stages are defined for Cottonwood (30 ft) and Neosho Rapids (17 ft). In comparison with the rating curves for each site, the flood action stage is closely correlated to the point when flow transitions from channel-control flow to overbank flow; therefore, associated flow at or above the flood action stage is considered to be, for the purpose of this analysis, greater than channelcontrol flow. The associated streamflow for the action stages was defined by computing the mean streamflow using each stage-discharge rating developed during the analysis period (2010-19).

There is no defined NWS flood action stage for Burlingame; however, there is a defined flood action stage for the site about 13 river miles upstream (Neosho River near Americus, USGS site 07179730). The drainage-area ratio method was used to estimate the flood action stage associated streamflow equivalent from the Neosho River near Americus site to Burlingame (Southard, 2013; Eash and Barnes, 2017). To use this method, sites need to be on the same stream, and the ratio is preferred to be between 0.5 and 1.5 (the ratio between Burlingame and Neosho River near Americus is 1.2). Like Cottonwood and Neosho Rapids, the associated streamflow for the estimated flood action stage at Burlingame was defined by computing the mean streamflow using each stagedischarge rating developed during the analysis period.

Annual-exceedance probabilities (AEPs) were computed for flood action stage associated streamflows. At Cottonwood, the available period of record of streamflow daily values used to compute AEPs was 1963-2019. At Neosho Rapids and Burlingame, the available period of record of streamflow daily values used to compute AEPs was 2009-19. AEPs were calculated using the Weibull formula for computing plotting position (Helsel and others, 2020): 


$$
A E P=100 \times\left(\frac{i}{n+1}\right)
$$

where
$A E P$
is the annual exceedance probability, or the probability that a given flow will be equaled or exceeded, (in percent);
$i \quad$ is the assigned rank position (dimensionless); and
$n \quad$ is the sample size of the daily streamflow dataset (dimensionless).

Streambank stabilization sites are implemented along many reaches of the rivers, and overbank flow conditions at these locations likely differ from overbank flow conditions at the gaged locations. There are limitations to this approach, mainly because of the dynamic nature of stream morphology, and these estimates are intended to examine the percentage of sediment transported during high-flow flooding events.

\section{Computation of Streamflow during Backwater Conditions}

A simple stage-discharge rating does not always accurately compute continuous streamflow at a streamgage. In those cases, a complex rating may be used. A complex rating consists of a stage-discharge relation, in addition to some other independent variable (Kennedy, 1984). Because of its close location to the reservoir, the Neosho Rapids site is affected by varying degrees of intermittent backwater from the reservoir. Backwater can be described as a body of water in which the flow is slowed or turned back by an obstruction (U.S. Geological Survey, 2013). Examples of obstructions are natural debris, such as leaves, logs, and sticks; a dam or bridge; and another body of water, such as a lake or river. At the Neosho Rapids site, a slope rating is used to continuously compute streamflow.

The most common method the USGS uses to compute streamflow at a streamgage is a simple stage-discharge rating (Kennedy, 1984). These ratings involve the relation of streamflow to stage and are used at the Cottonwood, Burlingame, and Burlington sites. Onsite measurements of streamflow that are made by USGS personnel are the main data source for this rating analysis. Other information that is sometimes used to improve the accuracy of a simple stage-discharge rating are a streamgage height of zero flow, dates of floods and other channel changing events, and cross-section surveys (Kennedy, 1984).

A slope rating is a complex rating that relates streamflow to stage at one gage (base gage) and to the fall in water surface elevation between the base gage and an auxiliary gage downstream (Kennedy, 1984). The slope rating at the Neosho Rapids site is composed of three parts: (1) a simple stage-discharge rating curve, (2) a fall rating curve that rates the fall between the base and auxiliary gage that varies with stage, and (3) a discharge factor rating curve that relates the ratio of measured streamflow to the rated streamflow versus the ratio of the measured fall to the rated fall. If the factor from the discharge factor curve is 1.0, then the streamgage is not affected by a backwater condition and the simple stagedischarge rating is used to compute streamflow. If the factor is less than 1.0, then the streamflow is adjusted using that factor. A more detailed explanation of simple and complex ratings is documented in Kennedy (1984).

Streamflow at the Neosho Rapids site was computed using a slope rating, and the auxiliary gage used for the slope computation was the Neosho River at Hartford, Kans. (USGS site 07182395; fig. 1). The slope rating for the Neosho Rapids site was implemented in March 2016. The slope rating computes streamflow when the stage at Neosho Rapids is between 1.53 and $23.42 \mathrm{ft}$. Since the slope rating was implemented in 2016, the streamflow at the Neosho Rapids site was affected by some degree of backwater from the reservoir a little more than one-half of the time through 2019. Before the slope rating, periods of backwater were estimated at the Neosho Rapids site using streamflow measurements made by USGS personnel more frequently and the Missing Streamflow Estimation regression tool in the HYDRA program present in the USGS Automated Data Processing System following USGS methods (Painter and Loving, 2015).

\section{Streamflow Conditions and Continuously Monitored Water-Quality Variables}

Streamflow is the major determinant of sediment fate and transport. Annual mean streamflow computed using daily mean streamflows for Cottonwood during 2010 through 2019 ranged from 226 to $2,070 \mathrm{ft}^{3} / \mathrm{s}$; the smallest mean streamflow was measured in 2012 and the largest was measured in 2019. Annual mean streamflow for Burlingame during 2010 through 2019 ranged from 67 to $973 \mathrm{ft}^{3} / \mathrm{s}$; the smallest mean streamflow was measured in 2014 and the largest was measured in 2019. Annual mean streamflow at Neosho Rapids ranged from 349 to $3,270 \mathrm{ft}^{3} / \mathrm{s}$ in 2012 and 2019 , respectively. Annual mean streamflow for Burlington ranged from 414 to $4,110 \mathrm{ft}^{3} / \mathrm{s}$ in 2012 and 2019, respectively (table 7).

Streamflow in the drainage basin can have rapid increases and subsequent decreases with corresponding rainfall. Streamflow duration curves for each study site show the frequency of exceedance for flows of different magnitudes (fig. 5). The 1-percent exceedance flows ranged from $19,200 \mathrm{ft}^{3} / \mathrm{s}$ at Neosho Rapids to $5,690 \mathrm{ft}^{3} / \mathrm{s}$ at Burlingame. The 99-percent exceedance flows ranged from $32 \mathrm{ft}^{3} / \mathrm{s}$ at Neosho Rapids to $2 \mathrm{ft}^{3} / \mathrm{s}$ at Burlingame.

The National Integrated Drought Information System recorded the longest history of drought conditions in Kansas, which began on November 9, 2010, and ended on August 4, 2015 , totaling 248 weeks. The most intense drought period 
Table 7. Total annual streamflow and annual mean streamflow for study sites along the Cottonwood and Neosho Rivers, Kansas, during 2010 through 2019.

[Cottonwood, Cottonwood River near Plymouth, Kansas (U.S. Geological Survey [USGS] site 07182250); Burlingame, Neosho River at Burlingame Road near Emporia, Kans. (USGS site 07179750); Neosho Rapids, Neosho River at Neosho Rapids, Kans. (USGS site 07182390); Burlington, Neosho River at Burlington, Kans. (USGS site 07182510); AF, acre-foot; $\mathrm{ft}^{3} / \mathrm{s}$, cubic foot per second; --, data not available]

\begin{tabular}{|c|c|c|c|c|c|c|c|c|c|c|c|}
\hline \multirow{2}{*}{ Year } & \multicolumn{2}{|c|}{ Cottonwood } & \multicolumn{2}{|c|}{ Burlingame } & \multicolumn{2}{|c|}{ Neosho Rapids } & \multicolumn{2}{|c|}{$\begin{array}{l}\text { Neosho Rapids (upstream } \\
\text { loads subtracted) }\end{array}$} & \multicolumn{2}{|c|}{ Burlington } & \multirow{2}{*}{$\begin{array}{c}\text { Total retained } \\
\text { by reservoir } \\
\text { (AF) }\end{array}$} \\
\hline & $\begin{array}{l}\text { Total } \\
\text { (AF) }\end{array}$ & $\begin{array}{r}\text { Mean } \\
\left(\mathrm{ft}^{3} / \mathrm{s}\right)\end{array}$ & $\begin{array}{l}\text { Total } \\
\text { (AF) }\end{array}$ & $\begin{array}{r}\text { Mean } \\
\left(\mathrm{ft}^{3} / \mathrm{s}\right)\end{array}$ & $\begin{array}{l}\text { Total } \\
\text { (AF) }\end{array}$ & $\begin{array}{l}\text { Mean } \\
\left(\mathrm{ft}^{3} / \mathrm{s}\right)\end{array}$ & $\begin{array}{l}\text { Total } \\
\text { (AF) }\end{array}$ & $\begin{array}{l}\text { Mean } \\
\left(\mathrm{ft}^{3} / \mathrm{s}\right)\end{array}$ & $\begin{array}{l}\text { Total } \\
\text { (AF) }\end{array}$ & $\begin{array}{l}\text { Mean } \\
\left(\mathrm{ft}^{3} / \mathrm{s}\right)\end{array}$ & \\
\hline 2010 & 779,000 & 1,080 & 413,000 & 570 & $1,760,000$ & 2,430 & 569,000 & 786 & $1,670,000$ & 2,300 & 90,000 \\
\hline 2011 & 188,000 & 260 & 107,000 & 147 & 361,000 & 498 & 66,000 & 91 & 353,000 & 488 & 8,000 \\
\hline 2012 & 164,000 & 226 & 64,700 & 89 & 253,000 & 349 & 24,000 & 34 & 301,000 & 414 & $-48,000$ \\
\hline 2013 & 623,000 & 860 & 64,200 & 89 & $1,180,000$ & 1,630 & 496,000 & 685 & 792,000 & 1,090 & 388,000 \\
\hline 2014 & 190,000 & 262 & 48,600 & 67 & 260,000 & 359 & 21,400 & 30 & 312,000 & 431 & $-52,000$ \\
\hline 2015 & 602,000 & 831 & 256,000 & 354 & $1,940,000$ & 2,680 & $1,090,000$ & 1,500 & $1,290,000$ & 1,780 & 650,000 \\
\hline 2016 & 728,000 & 1,000 & 305,000 & 419 & $1,210,000$ & 1,670 & 178,000 & 245 & $1,410,000$ & 1,940 & $-200,000$ \\
\hline 2017 & 517,000 & 714 & 270,000 & 372 & 917,000 & 1,270 & 131,000 & 181 & $1,010,000$ & 1,390 & $-93,000$ \\
\hline 2018 & 365,000 & 504 & 227,000 & 313 & 669,000 & 924 & 77,000 & 106 & 811,000 & 1,120 & $-142,000$ \\
\hline 2019 & $1,500,000$ & 2,070 & 704,000 & 973 & $2,360,000$ & 3,270 & 158,000 & 219 & $2,980,000$ & 4,110 & $-620,000$ \\
\hline Mean & 452,000 & -- & 177,000 & -- & 837,000 & -- & 140,000 & -- & 848,000 & -- & -- \\
\hline Total & $5,660,000$ & -- & $2,460,000$ & -- & $10,900,000$ & -- & $2,800,000$ & -- & $10,900,000$ & -- & -- \\
\hline
\end{tabular}

${ }^{1}$ Total retained by reservoir calculated by subtracting Burlington streamflow from Neosho Rapids streamflow. 


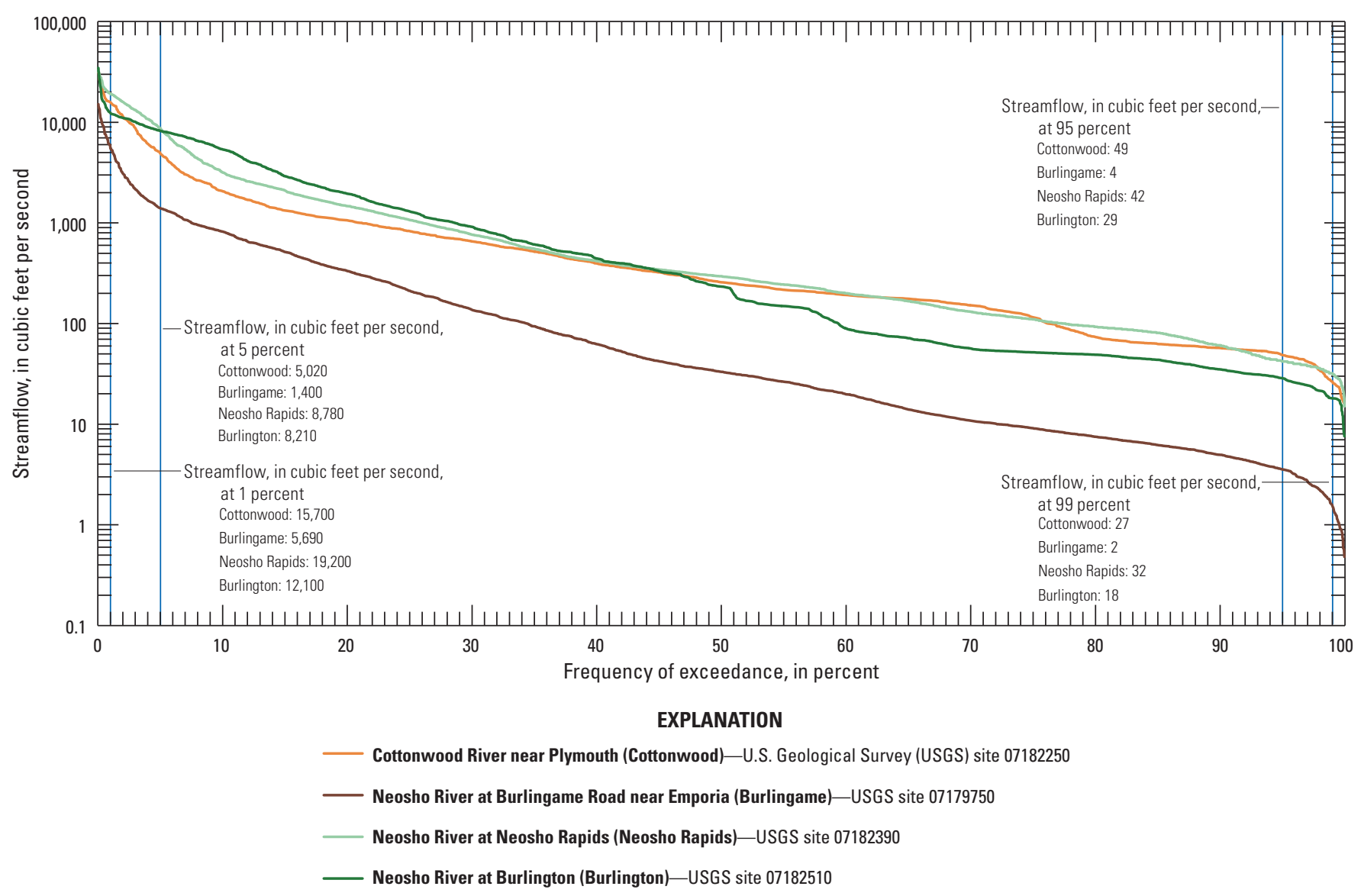

Figure 5. Streamflow duration curves with 1-, 5-, 95-, and 99-percent exceedances for the study sites along the Cottonwood and Neosho Rivers, Kansas, during 2010 through 2019.

occurred during August 2012 when nearly 67 percent of the State experienced exceptional drought including widespread crop and pasture losses and water shortages (National Integrated Drought Information System, 2020). The smallest total streamflows occurred during drought years (2011-15) for all sites. Cottonwood, Neosho Rapids, and Burlingame had the smallest annual streamflow during 2012, which also was the year with the smallest annual mean precipitation (22.4 in.) in the drainage basin (fig. 6, table 7, table 3). Streamflow at Burlingame was the smallest during 2014 (48,600 acre-ft), which had the third smallest annual precipitation (fig. 6, table 7, table 3). The largest annual streamflow for all four sites occurred during 2019 and was a result of flooding because of greater than mean rainfall totaling 49.6 in. (fig. 6, table 3). The year 2019 also had the largest number of extreme precipitation days and had a total of $14.9 \mathrm{in}$. of rain during six 24-hour periods that accounted for 30 percent of the total annual precipitation (table 3). Burlington had the largest annual streamflow in 2019 (2,980,000 acre-ft), followed by Neosho Rapids (2,360,000 acre-ft), Cottonwood $(1,500,000$ acre-ft), and lastly Burlingame (704,000 acre-ft; table 7).
The total streamflow at Cottonwood during 2010 through 2019 was about 5,660,000 acre-ft (mean: 452,000 acre$\mathrm{ft}$; table 7). Burlingame had a smaller total streamflow $(2,460,000$ acre-ft, mean: 177,000 acre-ft) than Cottonwood (table 7). Neosho Rapids includes inflow from the Cottonwood River (Cottonwood site) and upper Neosho River (Burlingame site) and had a total streamflow of 10,900,000 acre-ft (mean: 837,000 acre-ft; table 7). The Cottonwood River (streamflow estimated at Cottonwood) contributes about one-half of the computed total streamflow at Neosho Rapids (table 7). Streamflow from the upper Neosho River (streamflow estimated at Burlingame) and the contributing drainage area upstream from Neosho Rapids (Neosho Rapids [upstream loads subtracted]; table 7) make up the remaining part of the total streamflow estimated at Neosho Rapids. Despite uncertainty associated with streamflow computations, there could be other mitigating factors (natural or anthropogenically induced) that contribute to the estimated streamflow calculations. Burlington streamflow was mostly regulated by reservoir releases; therefore, the unregulated drainage area $\left(27 \mathrm{mi}^{2}\right)$ had minimal streamflow contribution. Burlington's total streamflow was 10,900,000 acre-ft (mean: 848,000 acre-ft; table 7). 


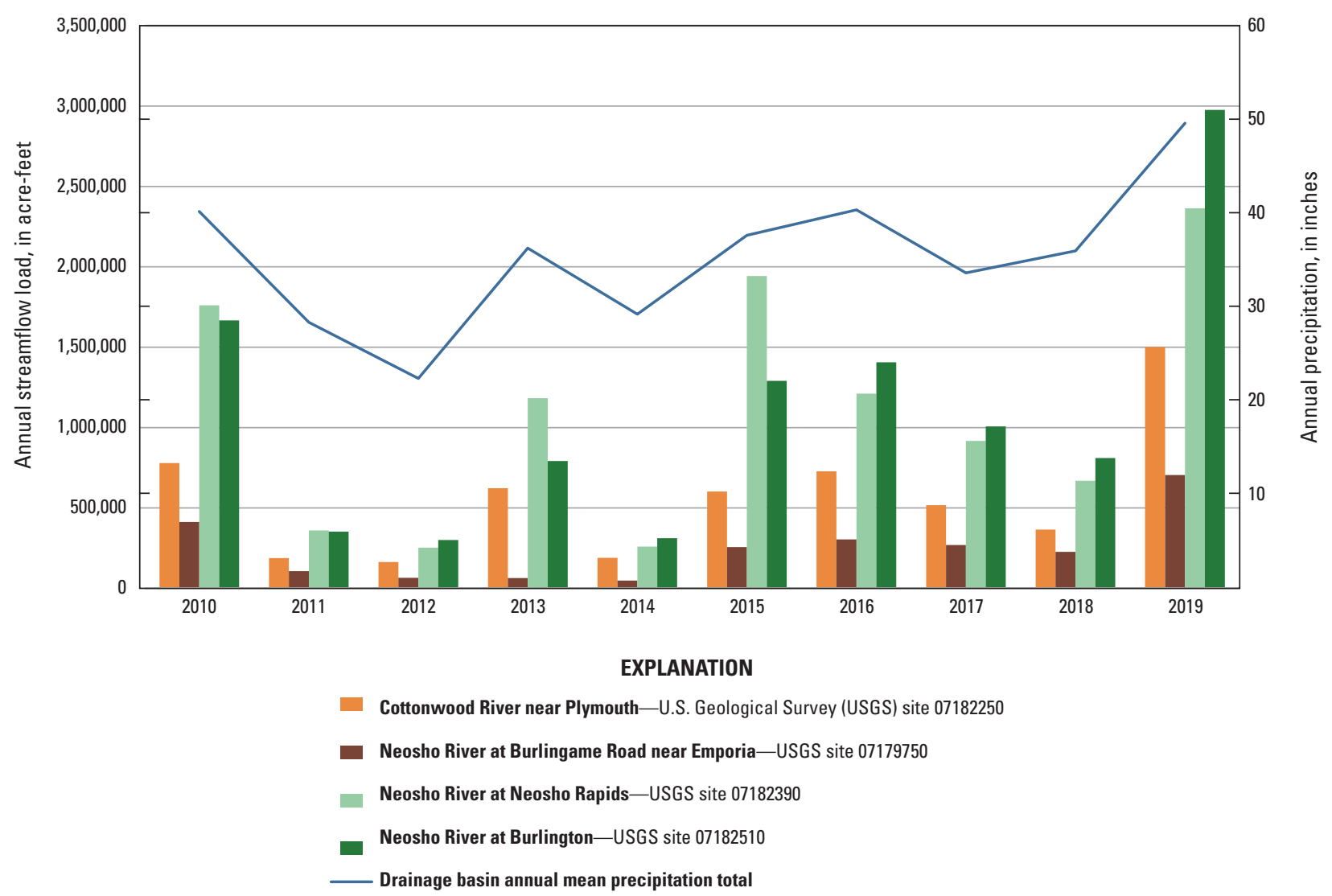

Figure 6. Annual basin mean precipitation totals and annual streamflow (in acre-feet) for study sites along the Cottonwood and Neosho Rivers, Kansas, during 2010 through 2019.

\section{Flooding during 2019}

In 2019, John Redmond Reservoir received 49.6 in. of precipitation, 38 percent more precipitation than recorded in 2018 (36.0 in.). The highest recorded precipitation totals were during the month of May (Council Grove Lake, 16.03 in.; Marion Reservoir, 9.91 in.; John Redmond Reservoir, 14.22 in.), which caused larger streamflows in the Cottonwood and upper Neosho Rivers and, in many areas, bank overflow. Mean streamflows were 2.4-3.5 times greater in 2019 than mean historical daily streamflows at all sites in the study area (tables 4, 7). As a result, many Kansas reservoirs, including John Redmond Reservoir, were filled to flood-control capacity in 2019 (U.S. Army Corps of Engineers, 2019a).

Reservoir releases increased substantially beginning in May 2019, and large streamflows continued through July 2019 (fig. 7, table 8). Total releases were largest for Council Grove Lake in May (51,910 acre-ft), Marion Reservoir in July (70,644 acre-ft), and John Redmond Reservoir in May (931,940 acre-ft) (U.S. Army Corps of Engineers, 2019b, c, d). The largest total rainfall was observed in May for all three reservoirs (16.03, 9.91, and 14.22 in., respectively). Additionally, all four sites had the largest streamflow totals in May (Cottonwood [707,000 acre-ft], Burlingame [308,000 acre$\mathrm{ft}$, Neosho Rapids [1,070,000 acre-ft], and Burlington
[936,000 acre-ft]; table 8). Larger 2019 streamflows quickly decreased water-storage capacity in many reservoirs across the State, including John Redmond Reservoir, which led to forced releases and contributed to larger streamflows downstream from the reservoirs.

\section{Continuous Water-Quality Variables}

The Kansas Department of Health and Environment (2018b) established a surface water-quality standard for streamflow to a receiving water not to raise or lower the natural conditions of water temperature beyond the mixing zone more than $3{ }^{\circ} \mathrm{C}$; however, this analysis was not included as part of this study. There are no established aquatic life criteria for specific conductance in natural waters in Kansas. Water temperature ranged from -0.8 to $38^{\circ} \mathrm{C}$ at all sites (table 4). Mean water temperatures were similar at all sites $\left(15-17^{\circ} \mathrm{C}\right)$. The range of measured water temperatures was largest at Burlingame and Neosho Rapids, which tend to be shallower at low flows. Specific conductance ranged from 66 to $1,240 \mu \mathrm{S} /$ $\mathrm{cm}$ at all sites (table 4). Specific conductance measurements typically were larger at Cottonwood and Neosho Rapids 

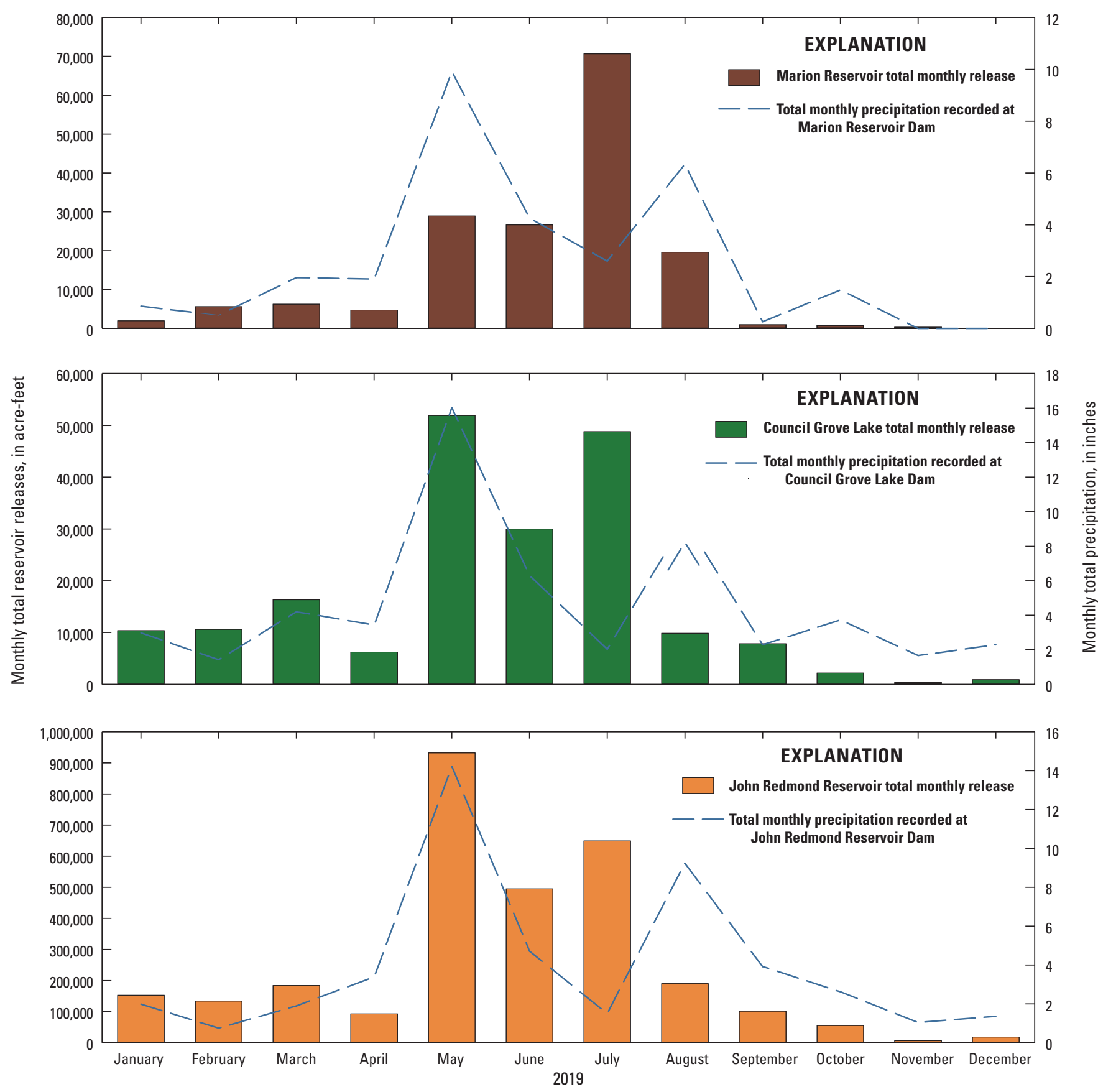

Figure 7. Monthly reservoir-release totals and rainfall totals for Marion Reservoir, Council Grove Lake, and John Redmond Reservoir, Kansas, 2019.

(mean: 708 and $623 \mu \mathrm{S} / \mathrm{cm}$, respectively) and smaller at Burlingame and Burlington (mean: 433 and $485 \mu \mathrm{S} / \mathrm{cm}$, respectively).

Turbidity is the measure of water clarity primarily changed by the presence of suspended material (clay, silt, and inorganic and organic matter). In addition to sediment depleting reservoir water-storage capacity, many pollutants, such as nutrients, pesticides, and metals, can adhere to sediment and can accumulate in the reservoir. The EPA established nonenforceable guidelines for turbidity in streams by region. Cottonwood and Burlingame are in level III ecoregion 28 with established nonenforceable guidelines for turbidity of 19.5 FNU (U.S. Environmental Protection Agency, 2001). Neosho Rapids and Burlington are in level IV ecoregion 40b with established nonenforceable guidelines for turbidity of $15.5 \mathrm{FNU}$. 
Table 8. Monthly reservoir releases, rainfall totals, and site total streamflow computed from daily total streamflow for Council Grove Lake, Marion Reservoir, and John Redmond Reservoir, Kansas, and for each of the streamgage sites, 2019.

[Data obtained from the U.S. Army Corps of Engineers Tulsa District (U.S. Army Corps of Engineers, 2019b, c, d). Cottonwood, Cottonwood River near Plymouth (U.S. Geological Survey [USGS] site 07182250); Burlingame, Neosho River at Burlingame Road near Emporia (USGS site 07179750); Neosho Rapids, Neosho River at Neosho Rapids (USGS site 07182390); Burlington, Neosho River at Burlington (USGS site 07182510); AF, acre-foot; in., inch]

\begin{tabular}{|c|c|c|c|c|c|c|c|c|c|c|c|c|c|c|}
\hline \multirow[b]{2}{*}{ Month } & \multicolumn{2}{|c|}{$\begin{array}{c}\text { Council Grove } \\
\text { Lake }\end{array}$} & \multicolumn{2}{|c|}{$\begin{array}{c}\text { Marion } \\
\text { Reservoir }\end{array}$} & \multicolumn{2}{|c|}{$\begin{array}{c}\text { John Redmond } \\
\text { Reservoir }\end{array}$} & \multicolumn{2}{|c|}{ Cottonwood } & \multicolumn{2}{|c|}{ Burlingame } & \multicolumn{2}{|c|}{ Neosho Rapids } & \multicolumn{2}{|c|}{ Burlington } \\
\hline & $\begin{array}{l}\text { Total } \\
\text { release } \\
\text { (AF) }\end{array}$ & $\begin{array}{l}\text { Rainfall } \\
\text { (in.) }\end{array}$ & $\begin{array}{c}\text { Total } \\
\text { release } \\
\text { (AF) }\end{array}$ & $\begin{array}{c}\text { Rainfall } \\
\text { (in.) }\end{array}$ & $\begin{array}{l}\text { Total } \\
\text { release } \\
\text { (AF) }\end{array}$ & $\begin{array}{c}\text { Rainfall } \\
\text { (in.) }\end{array}$ & $\begin{array}{l}\text { Total } \\
\text { streamflow } \\
\text { (AF) }\end{array}$ & $\begin{array}{c}\text { Contribution } \\
\text { from } \\
\text { upstream } \\
\text { reservoir } \\
\text { (percent) }\end{array}$ & $\begin{array}{l}\text { Total } \\
\text { streamflow } \\
\text { (AF) }\end{array}$ & $\begin{array}{c}\text { Contribution } \\
\text { from } \\
\text { upstream } \\
\text { reservoir } \\
\text { (percent) }\end{array}$ & $\begin{array}{l}\text { Total } \\
\text { streamflow } \\
\text { (AF) }\end{array}$ & $\begin{array}{c}\text { Contribution } \\
\text { from } \\
\text { upstream } \\
\text { reservoirs } \\
\text { (percent) }\end{array}$ & $\begin{array}{l}\text { Total } \\
\text { streamflow } \\
\text { (AF) }\end{array}$ & $\begin{array}{l}\text { Contribution } \\
\text { from upstream } \\
\text { reservoir } \\
\text { (percent) }\end{array}$ \\
\hline January & 10,368 & 2.98 & 1,970 & 0.86 & 152,702 & 1.98 & 66,200 & 3 & 37,700 & 28 & 117,000 & 11 & 150,000 & ${ }^{1} 102$ \\
\hline February & 10,616 & 1.42 & 5,619 & 0.51 & 133,930 & 0.74 & 48,100 & 12 & 34,900 & 30 & 91,500 & 18 & 127,000 & ${ }^{1} 105$ \\
\hline March & 16,308 & 4.2 & 6,246 & 1.97 & 183,740 & 1.89 & 90,700 & 7 & 50,600 & 32 & 155,000 & 15 & 179,000 & ${ }^{1} 103$ \\
\hline April & 6,222 & 3.43 & 4,756 & 1.91 & 92,758 & 3.38 & 51,800 & 9 & 25,300 & 25 & 75,400 & 15 & 87,700 & ${ }^{1} 106$ \\
\hline May & 51,910 & 16.03 & 28,941 & 9.91 & 931,940 & 14.22 & 707,000 & 4 & 308,000 & 17 & $1,070,000$ & 8 & 936,000 & 100 \\
\hline June & 30,014 & 6.3 & 26,658 & 4.26 & 494,556 & 4.71 & 190,000 & 14 & 80,400 & 37 & 301,000 & 19 & 445,000 & ${ }^{1} 111$ \\
\hline July & 48,798 & 2.03 & 70,644 & 2.6 & 648,898 & 1.49 & 175,000 & 40 & 67,300 & 72 & 254,000 & 47 & 656,000 & 99 \\
\hline August & 9,860 & 9.49 & 19,621 & 6.34 & 189,781 & 9.24 & 108,000 & 18 & 51,900 & 19 & 167,000 & 18 & 202,000 & 94 \\
\hline September & 7,851 & 2.29 & 952 & 0.26 & 101,073 & 3.92 & 21,900 & 4 & 21,200 & 37 & 53,100 & 17 & 101,000 & ${ }^{1} 100$ \\
\hline October & 2,190 & 3.72 & 811 & 1.49 & 55,169 & 2.61 & 15,400 & 5 & 7,550 & 29 & 28,200 & 11 & 63,200 & 87 \\
\hline November & 301 & 1.66 & 298 & 0.0 & 6,883 & 1.04 & 10,400 & 3 & 2,260 & 13 & 15,300 & 4 & 9,660 & 71 \\
\hline December & 924 & 2.29 & 83 & 0.0 & 18,125 & 1.36 & 16,900 & 0 & 16,900 & 5 & 38,800 & 3 & 19,500 & 93 \\
\hline
\end{tabular}

${ }^{1}$ Smaller total streamflow at Burlington than released from John Redmond Reservoir could be due to Wolf Creek Generating Station pumping water from the Neosho River just downstream from the reservoir to Coffey County Lake (National Regulatory Council, 2006). 
Continuously measured YSI EXO turbidity ranged from less than 1 to $1,640 \mathrm{FNU}$ with a mean of $60 \mathrm{FNU}$ at Cottonwood (table 4), and turbidity daily values exceeded the EPA nonenforceable guideline (19.5 FNU) about 63 percent of the time (fig. 8B). At Burlingame, continuously measured YSI 6600 model 6136 turbidity ranged from less than 1 to 2,450 FNU with a mean of 53 FNU and YSI EXO turbidity ranged from 2.3 to $2,300 \mathrm{FNU}$ with a mean of $51 \mathrm{FNU}$ (table 4 , fig. $8 A, B$ ). Turbidity daily values at Burlingame exceeded the EPA nonenforceable guideline (19.5 FNU) about 56 percent of the time during the analysis period. At Neosho Rapids, continuously measured YSI 6600 model 6136 turbidity ranged from 1.7 to $1,460 \mathrm{FNU}$ with a mean of $68 \mathrm{FNU}$ and YSI EXO turbidity ranged from 1.8 to $1,190 \mathrm{FNU}$ with a mean of 77 FNU (table 4, fig. $8 A, B$ ). Turbidity daily values at Neosho Rapids exceeded the EPA nonenforceable guideline (15.5 FNU) about 74 percent of the time during the analysis period. At Burlington, YSI 6600 model 6136 turbidity ranged from 3.9 to $760 \mathrm{FNU}$ with a mean of $29 \mathrm{FNU}$ and YSI EXO turbidity ranged from 3.3 to $1,640 \mathrm{FNU}$ with a mean of $28 \mathrm{FNU}$ (table 4, fig. $8 A, B$ ). Turbidity daily values at Burlington exceeded the EPA nonenforceable guideline ( $15.5 \mathrm{FNU}$ ) about 66 percent of the time during the analysis period.

High-flow daily mean turbidity values (1-5-percent exceedance) for the YSI 6600 model 6136 turbidity sensor at Neosho Rapids were larger than the values upstream at Burlingame or downstream at Burlington (fig. 8A). Low-flow daily turbidity values (99-percent exceedance) were largest at Burlington and smallest at Burlingame (fig. 8A). High-flow daily mean YSI EXO turbidity values (1-5 percent) were largest at Neosho Rapids, whereas turbidity values at both upstream sites, Cottonwood and Burlingame, were smaller and Burlington (downstream) was the smallest (fig. 8B). The YSI EXO low-flow daily turbidity values (99-percent exceedance) were largest at Burlington and smallest at Neosho Rapids (fig. 8B). At Burlington, regulation by the reservoir and lack of contributing drainage area downstream from John Redmond Dam likely contributed to a smaller range of turbidity values.

\section{Regression Models and Computed Concentrations, Loads, and Yields for Suspended Sediment}

Turbidity has been used to compute SSC in Kansas streams when silt and clay compose most of the suspended sediment (Christensen and others, 2000; Rasmussen and others, 2005; Lee and others, 2008; Rasmussen and others, 2008; Juracek, 2011; Stone and others, 2013, 2015; Foster, 2014). In selected samples collected during high flow with large turbidity values (greater than $500 \mathrm{FNU}$ ), suspended sediment was measured by weight for grain sizes of $0.002,0.004$,
$0.008,0.016,0.031,0.065$, and 1 millimeter $(\mathrm{mm})$. Silt and clay (less than $0.065 \mathrm{~mm}$ ) composed at least 85 percent of the selected samples by weight (appendix 13). Optical turbidity sensors are appropriate to compute suspended sediment because of the large percentage of fine material (silt and clay particles) present, including during high flow. Slope similarities among turbidity-SSC regression models for all four sites indicated that sediment grain size and color (the primary factors affecting those models) were similar among study sites, which coincided with findings in Lee and others (2008) and Foster (2014).

Regression models were developed using turbidity data collected during 2010 through 2019. Instream continuously measured variables for each study site included temperature, specific conductance, and turbidity. Previously published SSC models (Foster, 2014) were updated using new turbidity and SSC data (table 6).

A turbidity-SSC regression-computed time-series model is considered more reliable and reproducible than a streamflow-SSC regression-computed model (Rasmussen and others, 2009). Based on the $R^{2}$ from newly developed regression models, turbidity explained 92-99 percent of the variance in SSC and the streamflow-based regression models explained 45-77 percent of the variance (table 6). The MSPE for the turbidity-SSC regression model was 20.7-41.2 percent, and for the streamflow-SSC model, the MSPE was 70.2-108 percent (table 6). Prediction intervals (95 percent) were plotted along with regression relations among turbidity (YSI 6600 model 6136 and YSI EXO), streamflow, and SSC (figs. 9, 10, 11). The range of values within the 95 -percent prediction interval for turbidity-based regressions was much smaller than the range for the streamflow-based regressions, indicating better performance.

\section{Suspended-Sediment Concentrations, Loads, and Yields}

Computed daily mean concentrations of suspended sediment at Cottonwood ranged from 6 to 2,680 $\mathrm{mg} / \mathrm{L}$ (mean: $179 \mathrm{mg} / \mathrm{L}$ ) during 2015 through 2019 (partial years included; table 9). Annual mean SSC was largest in 2019 (244 mg/L) and smallest in $2018(116 \mathrm{mg} / \mathrm{L}$; table 10$)$. Computed daily loads for Cottonwood ranged from 1 to 176,000 tons (mean: 2,180 tons; table 9). The annual load was largest in 2019 $(1,800,000$ tons) and smallest in 2018 (261,000 tons; table 10$)$. At this site, annual data were not available during 2010 through 2015.

Computed daily mean concentrations of suspended sediment at Burlingame ranged from 1 to $3,180 \mathrm{mg} / \mathrm{L}$ (mean: $108 \mathrm{mg} / \mathrm{L}$ ) during 2010 through 2019 (partial years included; table 9). Annual mean SSC was largest in $2019(178 \mathrm{mg} / \mathrm{L})$ and smallest in $2012(70 \mathrm{mg} / \mathrm{L}$; table 10). Computed daily loads for Burlingame ranged from less than 1 to 75,900 tons (mean: 624 tons; table 9). The annual load was largest in 2019 


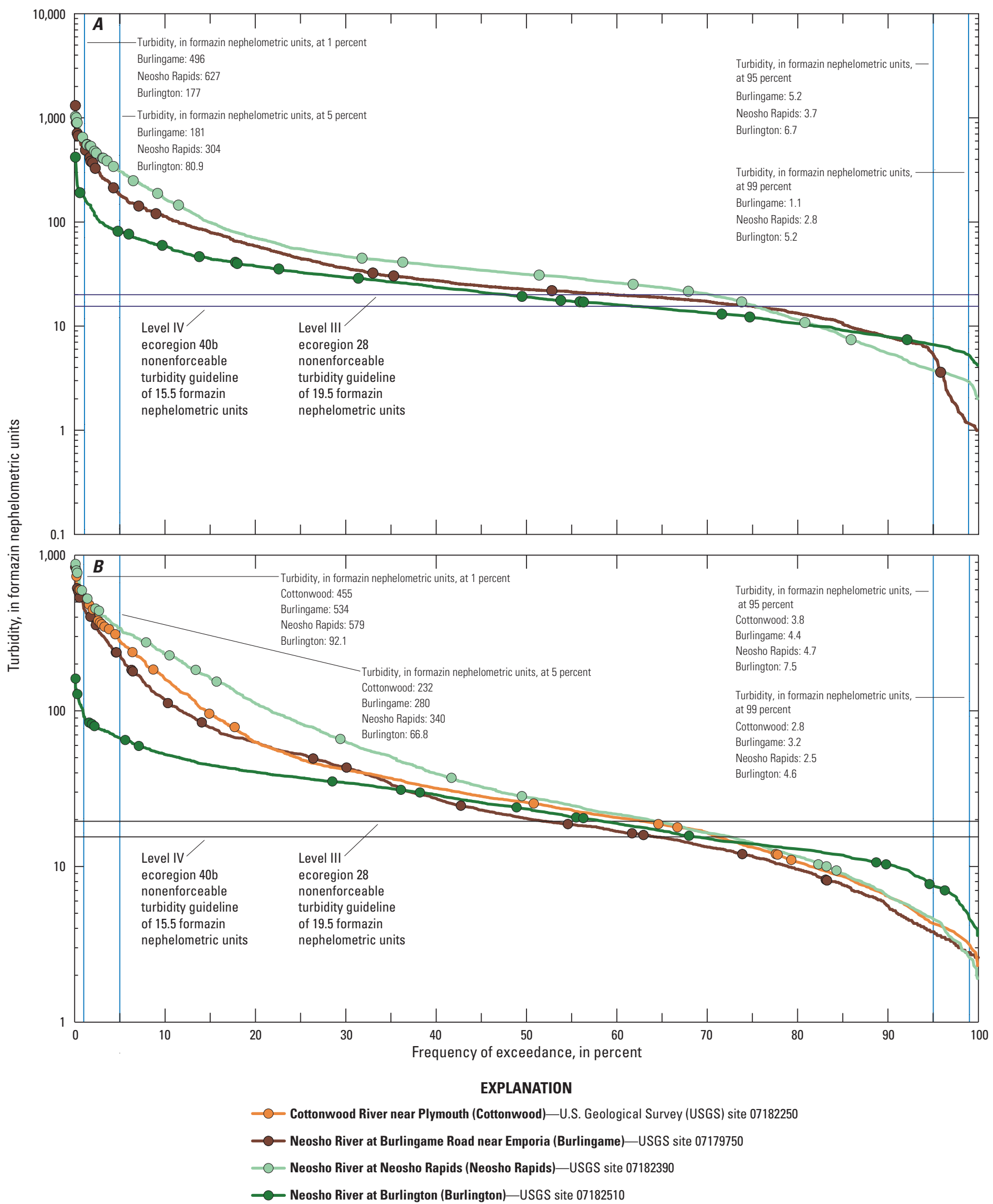

Figure 8. Duration curves of daily mean turbidity measurements for study sites along the Cottonwood and Neosho Rivers, Kansas, during 2010 through 2019. A, turbidity measured using YSI Incorporated 6600 Extended Deployment System monitor model 6136 turbidity sensor; $B$, turbidity measured using Xylem YSI EXO turbidity sensor. 

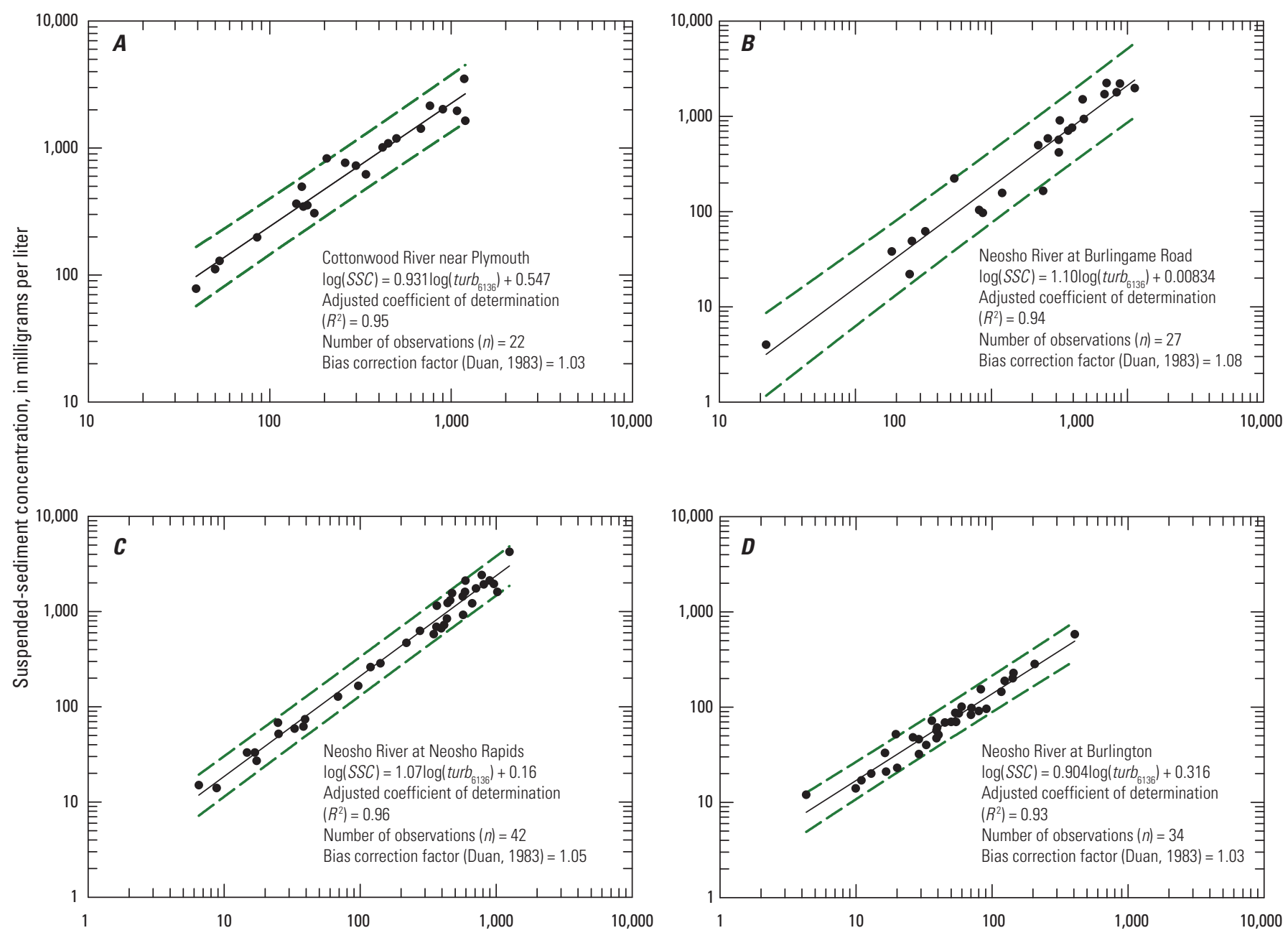

Turbidity, in formazin nephelometric units

\section{EXPLANATION}

[SSC, suspended-sediment concentration; turb $_{6136}$, YSI Incorporated 6600 Extended Deployment System model 6136 turbidity sensor value]

\section{Best-fit line \\ - 95-percent prediction interval}

- Discrete measurement

Figure 9. Regression relations between YSI Incorporated 6600 Extended Deployment System monitor model 6136 turbidity and suspended-sediment concentrations for study sites along the Cottonwood and Neosho Rivers, Kansas, during 2007 through 2015. $A$, Cottonwood River near Plymouth (U.S. Geological Survey [USGS] site 07182250); $B$, Neosho River at Burlingame Road near Emporia (USGS site 07179750); C, Neosho River at Neosho Rapids (USGS site 07182390); D, Neosho River at Burlington (USGS site 07182510).

(625,000 tons) and smallest in 2012 (37,200 tons; table 10). At this site, annual data were not available for 2013, 2014, and 2015.

Neosho Rapids was the only site with no large gaps in the continuous record for the analysis period (2010 through 2019). Computed daily mean concentrations of suspended sediment ranged from 3 to 2,750 $\mathrm{mg} / \mathrm{L}$ (mean: $162 \mathrm{mg} / \mathrm{L}$; table 9). Annual mean SSC was largest in 2019 (278 mg/L) and smallest in $2012(107 \mathrm{mg} / \mathrm{L})$, which corresponds to the years with the largest and smallest mean streamflow and greatest and least total annual precipitation, respectively (table 10, table 7 , table 3). Computed daily loads for Neosho Rapids ranged from less than 1 to 184,000 tons (mean: 2,250 tons; table 9). The annual load was largest in 2019 (2,540,000 tons) and smallest in 2012 (173,000 tons), which corresponds to the largest and smallest annual total streamflow respectively (table 10, table 7). 

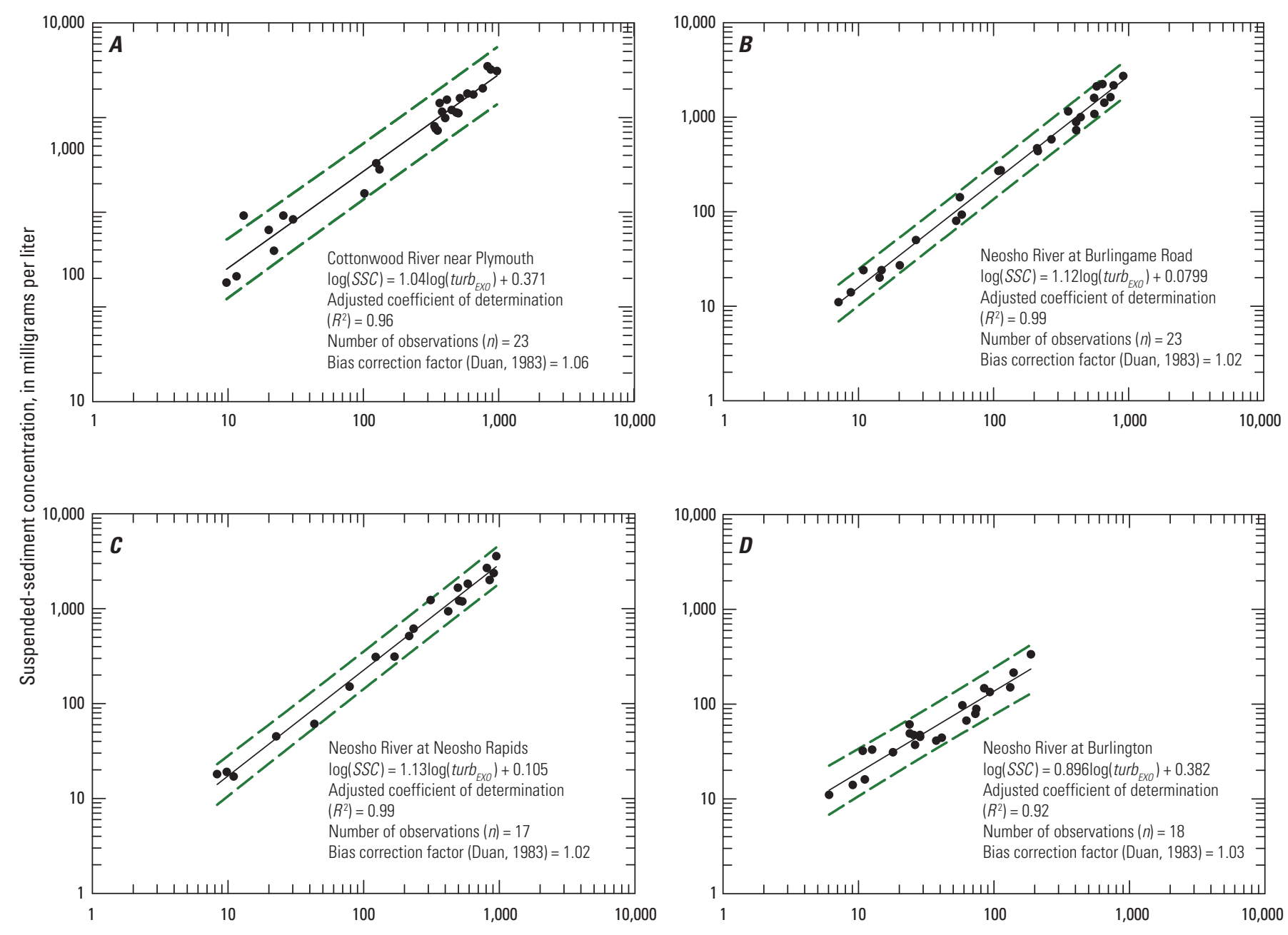

Turbidity, in formazin nephelometric units

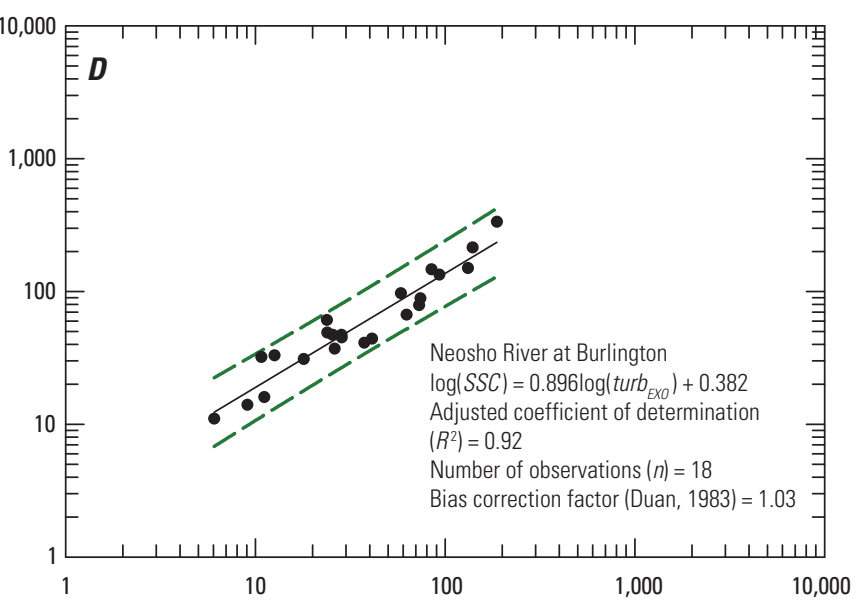

EXPLANATION

[SSC, suspended-sediment concentration; turb ${ }_{E X O}$, XYlem YSI EXO turbidity sensor value]

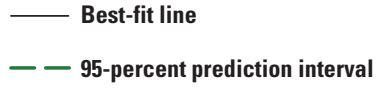

- Discrete measurement

Figure 10. Regression relations between Xylem YSI EXO, model EX02, turbidity and suspended-sediment concentrations for study sites along the Cottonwood and Neosho Rivers, Kansas, during 2015 through 2019. A, Cottonwood River near Plymouth (U.S. Geological Survey [USGS] site 07182250); $B$, Neosho River at Burlingame Road near Emporia (USGS site 07179750); C, Neosho River at Neosho Rapids (USGS site 07182390); $D$, Neosho River at Burlington (USGS site 07182510).

Computed daily mean concentrations of suspended sediment at Burlington ranged from 8 to $500 \mathrm{mg} / \mathrm{L}$ (mean: $46 \mathrm{mg} / \mathrm{L}$ ) during 2010 through 2019 (partial years included; table 9). Annual mean SSC was largest in $2010(67 \mathrm{mg} / \mathrm{L})$ and smallest in 2014 (27 mg/L; table 10). Computed daily loads for Burlington ranged from less than 1 to 9,860 tons (mean: 286 tons; table 9). The annual load was smallest in 2014 (18,800 tons) and largest in 2019 (305,000 tons; table 10). At this site, annual data were not available for 2011, 2012, and 2013.
The mean daily suspended-sediment load at Cottonwood (the Cottonwood River arm) was 3.5 times larger (2,180 tons) than at Burlingame (624 tons; the Upper Neosho arm). During the analysis period, Neosho Rapids had the largest mean daily suspended-sediment loads (2,250 tons) but was only 3 percent larger than the mean daily sediment load at Cottonwood. The mean daily sediment load at Burlington was the smallest of the four sites (286 tons), and this site consistently had the smallest annual suspended-sediment load throughout the analysis 

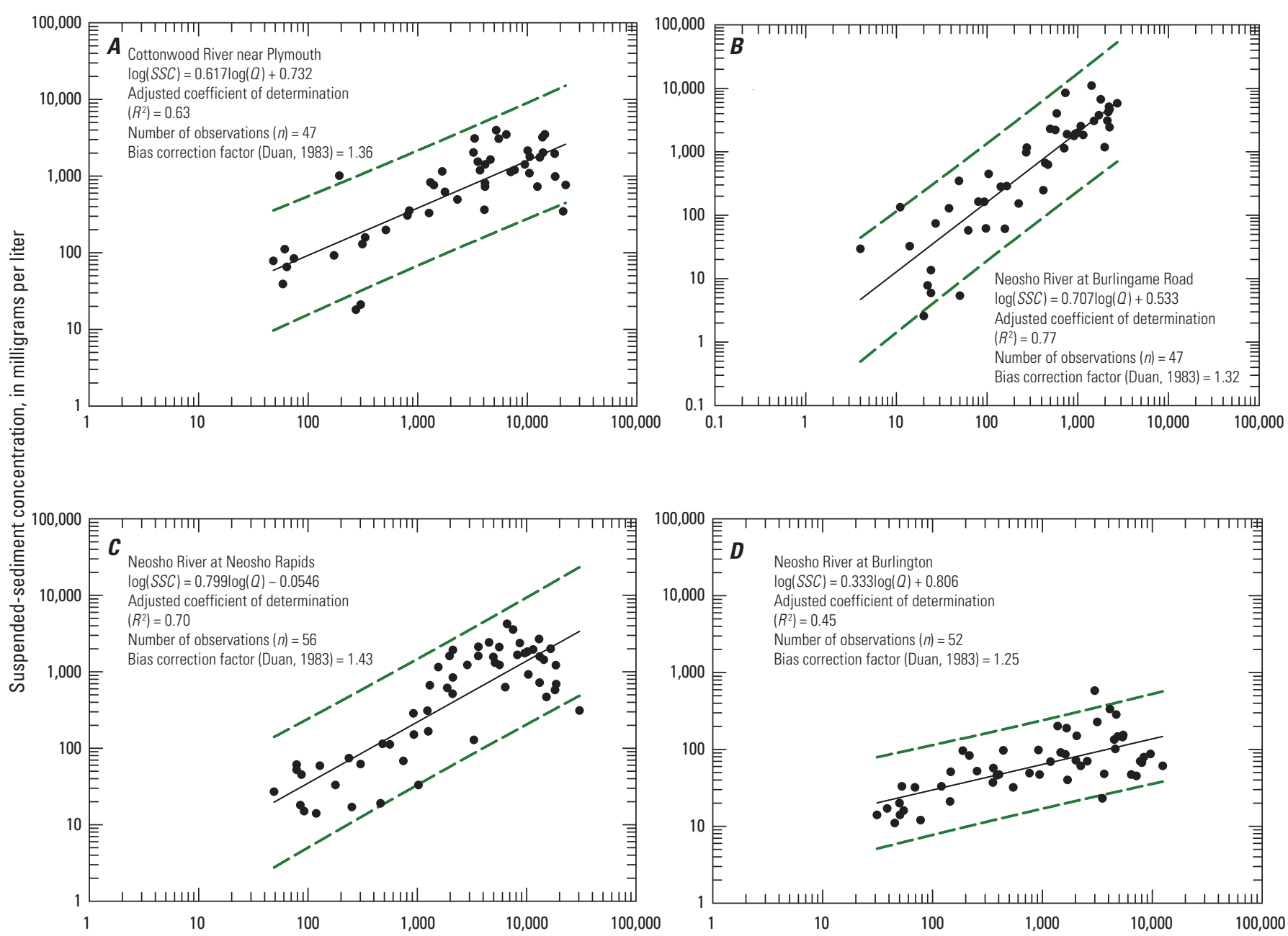

Streamflow, in cubic feet per second

\section{EXPLANATION}

[SSC, suspended-sediment concentration; Q, streamflow]

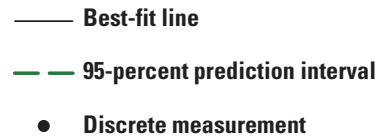

Figure 11. Regression relations between streamflow and suspended-sediment concentrations for study sites along the Cottonwood and Neosho Rivers, Kansas, during 2007 through 2019. A, Cottonwood River near Plymouth (U.S. Geological Survey [USGS] site 07182250); $B$, Neosho River at Burlingame Road near Emporia (USGS site 07179750); C, Neosho River at Neosho Rapids (USGS site 07182390); $D$, Neosho River at Burlington (USGS site 07182510).

period (table 10). Compared to Neosho Rapids (upstream from the reservoir), the mean daily load at Burlington (downstream from the reservoir) was 87 percent less.

Load duration curves were used to compare study sites. The top 1 percent of suspended-sediment daily loads, in decreasing order, were 51,500 tons at Neosho Rapids, 50,000 tons at Cottonwood, 18,500 tons at Burlingame, and 3,470 tons at Burlington (fig. 12). All sites had similar daily loads at the 99th percentile ranging from less than 1 to 1.7 tons (fig. 12). Duration curves for daily loads were comparable for
Cottonwood and Neosho Rapids. Daily suspended-sediment loads at Burlingame were typically (more than about 95 percent of the time) lower than the other sites (fig. 12). The duration curve of suspended-sediment loads at Burlington has characteristics expected of a site with predominantly regulated flow, with the smaller range of loads.

Suspended-sediment yields were calculated for all sites during years for which data were available. Cottonwood had yields ranging from $299,000 \mathrm{lb} / \mathrm{mi}^{2}$ in 2018 to $2,070,000 \mathrm{lb} /$ $\mathrm{mi}^{2}$ in 2019 (table 10). Burlingame yields ranged from 
Table 9. Suspended-sediment concentrations and suspended-sediment loads computed using daily mean values from regulated and unregulated drainage areas at monitoring sites along the Cottonwood and Neosho Rivers, Kansas.

[mg/L, milligram per liter; Cottonwood, Cottonwood River near Plymouth (U.S. Geological Survey [USGS] site 07182250); Burlingame, Neosho River at Burlingame Road near Emporia (USGS site 07179750); <, less than; Neosho Rapids, Neosho River at Neosho Rapids (USGS site 07182390); Burlington, Neosho River at Burlington (USGS site 07182510)]

\begin{tabular}{|c|c|c|}
\hline Summary statistic & $\begin{array}{l}\text { Suspended-sediment concentration } \\
\qquad(\mathrm{mg} / \mathrm{L})\end{array}$ & $\begin{array}{c}\text { Sediment load } \\
\text { (ton) }\end{array}$ \\
\hline \multicolumn{3}{|c|}{ Cottonwood (2015-19) } \\
\hline Minimum & 6 & 1 \\
\hline Maximum & 2,680 & 176,000 \\
\hline Mean & 179 & 2,180 \\
\hline Median & 69 & 41 \\
\hline \multicolumn{3}{|c|}{ Burlingame (2010-19) } \\
\hline Minimum & 1 & $<1$ \\
\hline Maximum & 3,180 & 75,900 \\
\hline Mean & 108 & 624 \\
\hline Median & 36 & 4 \\
\hline \multicolumn{3}{|c|}{ Neosho Rapids (2010-19) } \\
\hline Minimum & 3 & $<1$ \\
\hline Maximum & 2,750 & 184,000 \\
\hline Mean & 162 & 2,250 \\
\hline Median & 59 & 36 \\
\hline \multicolumn{3}{|c|}{ Burlington (2010-19) } \\
\hline Minimum & 8 & $<1$ \\
\hline Maximum & 500 & 9,860 \\
\hline Mean & 46 & 286 \\
\hline Median & 35 & 21 \\
\hline
\end{tabular}

$98,300 \mathrm{lb} / \mathrm{mi}^{2}$ in 2012 to $1,650,000 \mathrm{lb} / \mathrm{mi}^{2}$ in 2019 . Between the two upstream sites, Cottonwood had consistently higher yields except for 2017 when Burlingame had an estimated 1 percent higher yield than Cottonwood. Yields at Neosho Rapids ranged from $126,000 \mathrm{lb} / \mathrm{mi}^{2}$ in 2012 to $1,840,000 \mathrm{lb} /$ $\mathrm{mi}^{2}$ in 2019. There were 3 years $(2016,2018$, and 2019) where Cottonwood had higher estimated yields than Neosho Rapids (about 5, 1, and 12 percent higher, respectively). Burlington yields were substantially smaller than the other three sites, ranging from $12,400 \mathrm{lb} / \mathrm{mi}^{2}$ in 2014 to $201,000 \mathrm{lb} / \mathrm{mi}^{2}$ in 2019 (table 10).

During the analysis period, 2010 and 2019 had 6 days with extreme precipitation (defined as greater than 1.68 in. of rainfall within a 24-hour period) with a total basin mean accumulation of 14.5 and 14.9 in., respectively. These years correspond to the largest computed suspended-sediment concentrations, loads, and yields at the study sites along the
Cottonwood and Neosho Rivers. Nearly 25 percent of the total precipitation during the analysis period occurred during these extreme events, which totaled only 3824 -hour periods over 10 years (1.2 percent of the analysis period).

In comparison, 45-68 percent of the total sediment load at each upstream site (Cottonwood: 68 percent; Burlingame: 62 percent; Neosho Rapids: 45 percent) was transported during the top 38 loading days. Of the top 38 loading days for each site, 21 of the days for Cottonwood, 17 of the days for Neosho Rapids, and 15 of the days for Burlingame occurred in 2019. The estimated sediment load was about $490-590$ percent higher in 2019 than what was estimated for 2018 for all upstream sites and 310 percent higher in 2019 than 2018 at Burlington, downstream from the reservoir, indicating large sedimentation rates are driven by extreme events (high flow, precipitation, flooding) within this drainage basin. 
Table 10. Computed annual mean concentrations, loads, and yields of suspended sediment at monitoring sites on the Cottonwood and Neosho Rivers, Kansas.

[Cottonwood, Cottonwood River near Plymouth (U.S. Geological Survey [USGS] site 07182250); Burlingame, Neosho River at Burlingame Road near Emporia (USGS site 07179750); Neosho Rapids, Neosho River at Neosho Rapids (USGS site 07182390); Burlington, Neosho River at Burlington (USGS site 07182510 ); mg/L, milligram per liter; lb/mi ${ }^{2}$, pound per square mile; --, data not available]

\begin{tabular}{|c|c|c|c|c|c|c|c|c|c|c|c|c|}
\hline \multirow[b]{2}{*}{ Year } & \multicolumn{3}{|c|}{ Cottonwood } & \multicolumn{3}{|c|}{ Burlingame } & \multicolumn{3}{|c|}{ Neosho Rapids } & \multicolumn{3}{|c|}{ Burlington } \\
\hline & $\begin{array}{c}\text { Concentration } \\
(\mathrm{mg} / \mathrm{L})\end{array}$ & $\begin{array}{l}\text { Load } \\
\text { (ton) }\end{array}$ & $\begin{array}{c}\text { Yield }{ }^{1} \text { (Ib/ } \\
\left.\mathrm{mi}^{2}\right)\end{array}$ & $\begin{array}{c}\text { Concentration } \\
(\mathrm{mg} / \mathrm{L})\end{array}$ & $\begin{array}{l}\text { Load } \\
\text { (ton) }\end{array}$ & Yield ${ }^{1}\left(\mathrm{lb} / \mathrm{mi}^{2}\right)$ & $\begin{array}{c}\text { Concentration } \\
(\mathrm{mg} / \mathrm{L})\end{array}$ & $\begin{array}{l}\text { Load } \\
\text { (ton) }\end{array}$ & $\begin{array}{r}\text { Yield }{ }^{1} \\
\left(\mathrm{lb} / \mathrm{mi}^{2}\right) \\
\end{array}$ & $\begin{array}{c}\text { Concentration } \\
(\mathrm{mg} / \mathrm{L})\end{array}$ & $\begin{array}{l}\text { Load } \\
\text { (ton) }\end{array}$ & $\begin{array}{c}\text { Yield }^{1} \\
\left(\mathrm{lb} / \mathrm{mi}^{2}\right)\end{array}$ \\
\hline 2010 & -- & -- & -- & 145 & 314,000 & 830,000 & 222 & $1,230,000$ & 892,000 & 67 & -- & -- \\
\hline 2011 & -- & -- & -- & 88 & 51,200 & 135,000 & 139 & 256,000 & 186,000 & -- & -- & -- \\
\hline 2012 & -- & -- & -- & 70 & 37,200 & 98,300 & 107 & 173,000 & 126,000 & -- & -- & -- \\
\hline 2013 & -- & -- & -- & -- & -- & -- & 125 & 442,000 & 321,000 & -- & -- & -- \\
\hline 2014 & -- & -- & -- & -- & -- & -- & 111 & 307,000 & 223,000 & 27 & 18,800 & 12,400 \\
\hline 2015 & -- & -- & -- & -- & -- & -- & 189 & $1,030,000$ & 750,000 & 32 & 76,600 & 50,300 \\
\hline 2016 & 190 & 709,000 & 815,000 & 93 & 231,000 & 610,000 & 197 & $1,070,000$ & 779,000 & 55 & 146,000 & 95,700 \\
\hline 2017 & 126 & 381,000 & 438,000 & 94 & 167,000 & 442,000 & 143 & 758,000 & 551,000 & 37 & 82,600 & 54,300 \\
\hline 2018 & 116 & 261,000 & 299,000 & 72 & 107,000 & 282,000 & 113 & 410,000 & 298,000 & 40 & 74,900 & 49,300 \\
\hline 2019 & 244 & $1,800,000$ & $2,070,000$ & 178 & 625,000 & $1,650,000$ & 278 & $2,540,000$ & $1,840,000$ & 66 & 305,000 & 201,000 \\
\hline
\end{tabular}

${ }^{1}$ Yield is calculated using short tons (U.S. customary units) and the contributing drainage area in the drainage basin upstream from the location of the sites. 


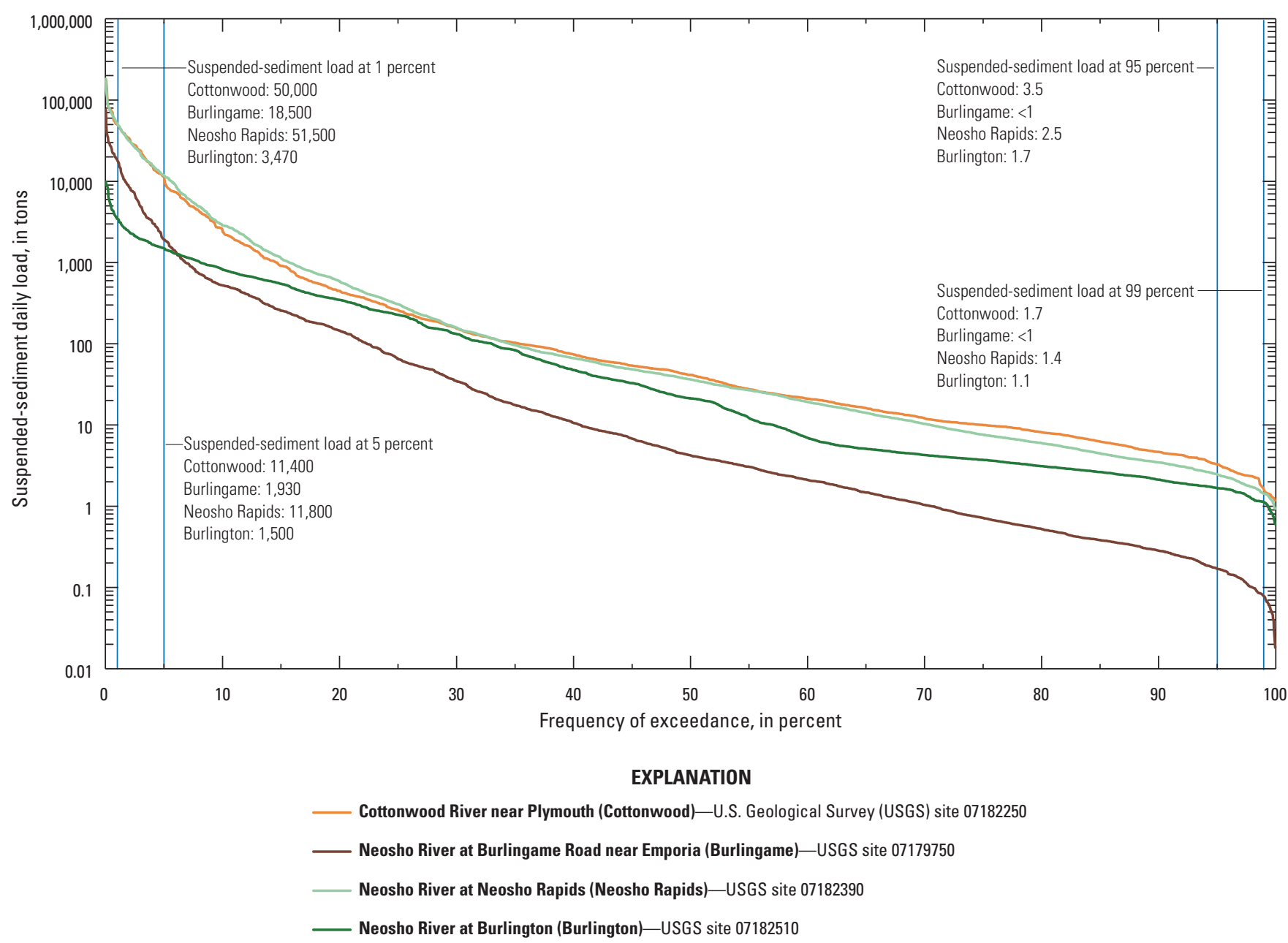

Figure 12. Duration curves of estimated daily suspended-sediment loads for study sites along the Cottonwood and Neosho Rivers, Kansas, during 2010 through 2019.

\section{Sediment Trapping in John Redmond Reservoir}

Sediment trapping efficiency, expressed as a percentage, was estimated as the total annual suspended-sediment load removed from the reservoir by releases (Burlington) subtracted from the total annual load delivered to the reservoir (Neosho Rapids). Using only years for which the Neosho Rapids and Burlington sites had continuous water-quality monitoring data (years 2010, 2014-19), estimated sediment loads were used to calculate the amount of sediment retained annually by the reservoir (table 11, fig. 13). A potential source of error in estimating sediment storage and trapping efficiency was large logjams just upstream from the reservoir, which may cause sediment to settle out of the water column before entering the reservoir (U.S. Army Corps of Engineers, 2005; Lee and others, 2008). Additional possible sources of error include the entrainment and transport of sediment from channel banks between Neosho Rapids and the reservoir and between the reservoir outflow and Burlington.
During years when concurrent load estimates were available for Neosho Rapids and Burlington (2010, 2014-19), an estimated total of 7,340,000 tons (mean: 1,050,000 tons) of sediment entered the reservoir (Neosho Rapids) and 895,000 tons (mean: 128,000 tons) were released downstream (Burlington). The difference is about 6,450,000 tons of sediment trapped in the reservoir during those 7 years, an 89-percent trapping efficiency. This compares closely with Lee and others (2008), who determined that during February 21, 2007, through February 21, 2008, an estimated 1,120,000 tons were transported into the reservoir and only 100,700 tons were transported downstream past Burlington, a 91-percent trapping efficiency. The lower trapping efficiency could be due to not including estimates for the ungaged 9 percent of the drainage basin in the computations.

The largest suspended-sediment load retained by the reservoir was during 2019 (2,230,000 tons), which corresponds to the largest annual mean streamflow for Neosho Rapids and Burlington (3,270 and 4,110 $\mathrm{ft}^{3} / \mathrm{s}$, respectively; table 7) and resulted in an 88-percent trapping efficiency. The largest trapping efficiency was in 2014 (94 percent) when 
Table 11. Estimated annual suspended-sediment load upstream and downstream from the reservoir, amount of load retained, and trapping efficiency of John Redmond Reservoir, Kansas.

[Neosho Rapids, Neosho River at Neosho Rapids (U.S. Geological Survey [USGS] site 07182390); Burlington, Neosho River at Burlington (USGS site 07182510); --, data not available]

\begin{tabular}{lcccc}
\hline Year & \multicolumn{2}{c}{ Total sediment load (ton) } & $\begin{array}{c}\text { Sediment load retained } \\
\text { by reservoir (ton) }\end{array}$ & $\begin{array}{c}\text { Reservoir trap- } \\
\text { ping efficiency } \\
\text { (percent) }\end{array}$ \\
\cline { 2 - 5 } & Neosho Rapids & Burlington & $1,040,000$ & 84.4 \\
2010 & $1,230,000$ & 191,000 & -- & -- \\
2011 & 256,000 & - & -- & -- \\
2012 & 173,000 & -- & -- & -- \\
2013 & 442,000 & -- & 288,000 & 93.9 \\
2014 & 307,000 & 18,800 & 953,000 & 92.6 \\
2015 & $1,030,000$ & 76,600 & 924,000 & 86.4 \\
2016 & $1,070,000$ & 146,000 & 675,000 & 89.1 \\
2017 & 758,000 & 82,600 & 335,000 & 81.7 \\
2018 & 410,000 & 74,900 & $2,230,000$ & 88.0 \\
2019 & $2,540,000$ & 305,000 & $6,450,000$ & -- \\
Total & $8,220,000$ & 895,000 & 921,000 & 89.1 \\
Mean & 822,000 & 128,000 & 924,000 & 88.0 \\
Median & 600,000 & 82,600 & & \\
\hline
\end{tabular}

mean streamflow was second smallest (2012 had the smallest mean streamflow) at Neosho Rapids and Burlington because of drought conditions (mean: 359 and $431 \mathrm{ft}^{3} / \mathrm{s}$, respectively). Sufficient data were not available for computations for 2012. During drought years, reservoir releases are minimal, effectively trapping most, if not all, of the suspendedsediment influx.

Suspended-sediment loads and the mean bulk density of the sediment historically deposited in the reservoir were used to estimate the storage capacity of the reservoir lost to sedimentation (Foster, 2016). Juracek (2010) used sediment cores to determine a representative bulk density for the reservoir by averaging the mean bulk density of four individual cores (38.2 pounds per cubic foot). By converting total sediment load in tons to pounds and dividing by the representative bulk density, the storage capacity lost to sedimentation can be estimated. During years with complete annual datasets at Neosho Rapids and Burlington (2010, 2014-19), about 7,750 acre-ft was lost because of sedimentation assuming all sediment was deposited in the multipurpose pool area. In 2019, the reservoir lost an estimated 2,680 acre-ft of reservoir storage to sedimentation. To obtain an estimate for the analysis period, including years with missing retained load estimations because of missing data at Burlington (2011-13; table 11), the incoming load at Neosho Rapids was multiplied by the mean reservoir trapping efficiency ( 89 percent) to estimate the load retained in the reservoir (230,000 tons, 155,000 tons, and 397,000 tons during 2011-13, respectively). The estimated total load retained in the reservoir during 2010-19 was about 8,690 acre-ft (mean annual load: 723,000 tons), about 17 percent of the remaining storage space (50,200 acre-ft) reported in 2007 (Juracek, 2010). The reservoir designed sedimentation rate was 404 acre-ft/yr and previous studies determined the sedimentation rate was much higher; during 1964-2010, the U.S. Army Corps of Engineers (2016) estimated a sedimentation rate of 736 acre-ft/yr, and during 2007-14, Jakubauskas and others (2014) estimated a sedimentation rate of 492 acre-ft/yr. During the analysis period, the mean annual sedimentation rate was about 747 acre-ft/yr, higher than the 1964-2010 and 2007-14 estimations and about 85 percent more than the designed reservoir sedimentation rate.

A dredging operation removed about 3 million cubic yards ( $\mathrm{yd}^{3}$; about 1,860 acre-ft) of sediment from the reservoir in 2016 (Kansas Water Office, 2017). During 2010 through 2019 , about $14,000,000 \mathrm{yd}^{3}$ of sediment were deposited into the reservoir. In 2019 , about 4.3 million $\mathrm{yd}^{3}$ of sediment were retained in the reservoir from flooding that occurred in the drainage basin. Reservoir outflow management models indicated a 3-percent reduction in overall sediment trapping in the reservoir if mean residence times were kept short and the reservoir was operated near normal operating capacity as opposed to higher flood pool levels (Lee and Foster, 2013). During 2010 through 2019, a 3-percent reduction in the total sediment deposited to the reservoir is equal to about 261 acre$\mathrm{ft}$. That potential sediment reduction equals about 14 percent of the total sediment removed as part of the $\$ 20$ million dredging project. Results from this study demonstrate that sediment deposits during large inflow events were substantially larger 


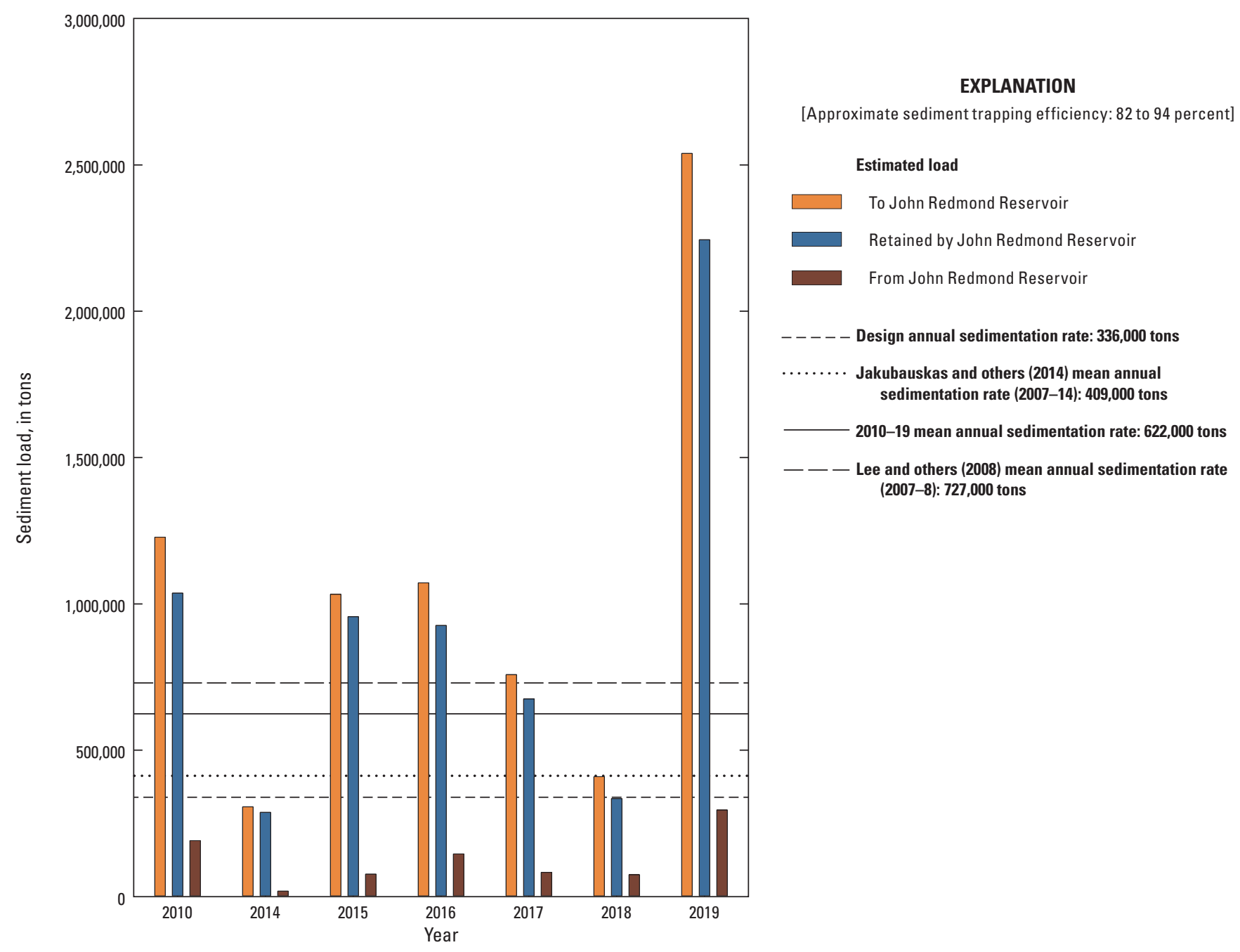

Figure 13. Estimated sediment loads into and out of John Redmond Reservoir, Kansas, and the resulting load retained in the reservoir during 2010 and 2014-19.

than previously dredged quantities of sediment and managing outflows could minimize sediment accumulation while still preserving flood control.

\section{Suspended Sediment Transported during High-Flow Events and Relations to Streambank Stabilization}

To estimate greater than channel-control streamflows, associated streamflow for the NWS flood action stage was defined at all upstream study sites. The flood action stage at Cottonwood was $30 \mathrm{ft}$; nine stage-discharge ratings during the analysis period were averaged, and the corresponding streamflow was $12,300 \mathrm{ft}^{3} / \mathrm{s}$ (standard deviation: $1,310 \mathrm{ft}^{3} / \mathrm{s}$ ). At Cottonwood, this streamflow had a 1-percent AEP. The flood action stage at Neosho Rapids was $17 \mathrm{ft}$; three stagedischarge ratings during the analysis period were averaged, and the corresponding streamflow was $11,500 \mathrm{ft}^{3} / \mathrm{s}$ (standard deviation: $\left.899 \mathrm{ft}^{3} / \mathrm{s}\right)$. At Neosho Rapids, this streamflow had a 2.2-percent AEP. The drainage-area ratio estimated streamflow for Burlingame was $7,010 \mathrm{ft}^{3} / \mathrm{s}$ (standard deviation: $515 \mathrm{ft}^{3} / \mathrm{s}$ ) based on four stage-discharge ratings and a flood action stage of $21 \mathrm{ft}$ upstream at the Neosho River near Americus. At Burlingame, this streamflow had a 0.7-percent AEP.

During 2016 through 2019 at Cottonwood, 48 percent of the total suspended-sediment load was transported when streamgage height was above the flood action stage and streamflows were greater than $12,300 \mathrm{ft}^{3} / \mathrm{s}$ (26 days, 1.8 percent of record). During 2010 through 2019 at Burlingame (excluding 2013-15 because of incomplete records), 40 percent of the total suspended-sediment load was transported when streamgage height was above the flood action stage and streamflows were greater than $7,010 \mathrm{ft}^{3} / \mathrm{s}$ (23 days, 0.1 percent of record). During 2010 through 2019 at Neosho Rapids, 78 percent of the total suspended-sediment load was transported when streamgage height was above the flood action stage and streamflows were greater than $11,500 \mathrm{ft}^{3} / \mathrm{s}$ 
Table 12. Total suspended-sediment load and suspended-sediment load when streamflow is greater than flood action stage associated streamflow for sites upstream from John Redmond Reservoir, Kansas.

[Cottonwood, Cottonwood River near Plymouth (U.S. Geological Survey [USGS] site 07182250); Burlingame, Neosho River at Burlingame Road near Emporia (USGS site 07179750); Neosho Rapids, Neosho River at Neosho Rapids (USGS site 07182390); --, data not available]

\begin{tabular}{|c|c|c|c|c|c|c|c|c|c|}
\hline \multirow[b]{2}{*}{ Year } & \multicolumn{3}{|c|}{ Cottonwood } & \multicolumn{3}{|c|}{ Burlingame } & \multicolumn{3}{|c|}{ Neosho Rapids } \\
\hline & $\begin{array}{l}\text { Total load } \\
\text { (ton) }\end{array}$ & $\begin{array}{c}\text { Total load } \\
\text { above flood } \\
\text { action stage } \\
\text { (ton) }\end{array}$ & $\begin{array}{l}\text { Percent } \\
\text { of total } \\
\text { load }\end{array}$ & $\begin{array}{l}\text { Total load } \\
\text { (ton) }\end{array}$ & $\begin{array}{c}\text { Total load } \\
\text { above flood } \\
\text { action stage } \\
\text { (ton) }\end{array}$ & $\begin{array}{l}\text { Percent } \\
\text { of total } \\
\text { load }\end{array}$ & $\begin{array}{l}\text { Total load } \\
\text { (ton) }\end{array}$ & $\begin{array}{c}\text { Total load } \\
\text { above flood } \\
\text { action stage } \\
\text { (ton) }\end{array}$ & $\begin{array}{l}\text { Percent of } \\
\text { total load }\end{array}$ \\
\hline 2010 & -- & -- & -- & 314,000 & 114,000 & 36 & $1,230,000$ & 973,000 & 79 \\
\hline 2011 & -- & -- & -- & 51,200 & -- & -- & 256,000 & 151,000 & 59 \\
\hline 2012 & -- & -- & -- & 37,200 & -- & -- & 173,000 & 86,000 & 50 \\
\hline 2013 & -- & -- & -- & -- & -- & -- & 442,000 & 299,000 & 68 \\
\hline 2014 & -- & -- & -- & -- & -- & -- & 307,000 & 222,000 & 72 \\
\hline 2015 & -- & -- & -- & -- & -- & -- & $1,030,000$ & 810,000 & 78 \\
\hline 2016 & 709,000 & 143,000 & 20 & 231,000 & 142,000 & 62 & $1,070,000$ & 808,000 & 75 \\
\hline 2017 & 381,000 & 211,000 & 55 & 167,000 & 27,600 & 17 & 758,000 & 615,000 & 81 \\
\hline 2018 & 261,000 & 118,000 & 45 & 107,000 & 24,500 & 23 & 410,000 & 300,000 & 73 \\
\hline 2019 & $1,800,000$ & $1,040,000$ & 58 & 625,000 & 311,000 & 50 & $2,540,000$ & $2,170,000$ & 86 \\
\hline Total & $3,150,000$ & $1,510,000$ & 48 & $1,530,000$ & 619,000 & 40 & $8,220,000$ & $6,430,000$ & 78 \\
\hline
\end{tabular}

${ }^{1}$ Daily streamflow greater than or equal to 12,300 cubic feet per second $\left(\mathrm{ft}^{3} / \mathrm{s}\right)$.

${ }^{2}$ Daily streamflow greater than or equal to $7,010 \mathrm{ft}^{3} / \mathrm{s}$.

${ }^{3}$ Daily streamflow greater than or equal to $11,500 \mathrm{ft}^{3} / \mathrm{s}$.

(184 days, 5 percent of record). Annually, the percentage of total loads from greater than flood action stage streamflows ranged from 17 to 86 percent (table 12).

Stream channel banks and surrounding areas are likely a more important source of sediment to the reservoir from the upstream drainage basin compared to channel beds (Straub and others, 2006; Juracek, 2010). Linking changes in sediment loads to causal factors requires monitoring before, during, and after changes, which presents challenges related to length, frequency, and scale of data collection in addition to available streambank stabilization data. Disproportionately large sediment loads are delivered during short periods of time, and localized efforts of stream erosion protection (streambank stabilization, riparian buffers) are likely to be overwhelmed during extreme conditions. Precipitation frequency and intensity are projected to continue to increase in this region (Shafer and others, 2014; Kloesel and others, 2018); therefore, future sediment reduction strategies that account for extreme episodic events may be beneficial. Continued investigation of sediment reduction measures is necessary for future mitigation with the understanding that sedimentation rate is largely driven by high flows. 


\section{Summary}

Streambank erosion and reservoir sedimentation are primary concerns of resource managers in Kansas and throughout many regions of the United States and negatively affect flood control, water supply, and recreation. John Redmond Reservoir, in east-central Kansas, has a primarily agricultural drainage basin of about 3,015 square miles that is drained by the Cottonwood and upper Neosho Rivers. Since the completion of the reservoir in 1964, there has been rapid sedimentation of its conservation pool. Channel banks and surrounding areas were more likely the source of sediment to the reservoir than channel beds. In an effort to reduce the amount of sediment transported to the reservoir, the Kansas Water Office implemented streambank stabilization projects along sections of the Cottonwood and upper Neosho Rivers. The U.S. Geological Survey (USGS), in cooperation with the Kansas Water Office, has been monitoring water quality at four sites within the drainage basin.

Daily precipitation during the analysis period was available from multiple Global Historical Climatology Network stations in the drainage basin. A mean of the annual precipitation and extreme precipitation days at three Global Historical Climatology Network stations was taken to represent a basin mean because precipitation can vary spatially. The mean annual precipitation during 2010 through 2019 was 35.4 inches (in.) and ranged from 22.4 to 49.6 in. in 2012 and 2019 , respectively. The top 1 percent of daily precipitation during a 100-year period was used to define extreme precipitation (1.68 in.). During the analysis period, the annual number of days with extreme precipitation ranged from 2 to 6 days with annual precipitation totals from those events ranging from 3.9 to $14.9 \mathrm{in}$. Although the number of extreme precipitation days (38 days) only accounted for about 1 percent of the analysis period, the total accumulated precipitation during these events accounted for 24 percent of the total precipitation. A substantial part of the total annual precipitation occurred during these extreme events during a disproportionately small amount of time and can result in increased runoff and sediment erosion.

Real-time water-quality monitors, measuring water temperature, specific conductance, and turbidity, collected continuous water-quality readings every 15 -minutes during January 1, 2010, through December 31, 2019. Waterquality monitors at Cottonwood River near Plymouth, Kansas (USGS site 07182250; hereinafter referred to as "Cottonwood"); Neosho River at Burlingame Road near Emporia, Kans. (USGS site 07179750; hereinafter referred to as "Burlingame"); and Neosho River at Burlington, Kans. (USGS site 07182510; hereinafter referred to as "Burlington”), were removed (various dates) during the analysis period for various reasons, including low flow from drought conditions, and then reinstalled (various dates). Three water-quality monitoring sites were upstream from John Redmond Reservoir (Cottonwood, Burlingame, and Neosho River at Neosho Rapids, Kans. [USGS site 07182390; hereinafter referred to as "Neosho Rapids"]) and one water-quality monitoring site was located downstream from the reservoir (Burlington). In 2015, the YSI Incorporated 6600 Extended Deployment System water-quality monitors (hereinafter referred to as "YSI 6600") were removed and replaced with Xylem YSI EXO, model EXO 2, continuous water-quality monitors (hereinafter referred to as "YSI EXO"). Water temperature and specific conductance are considered comparable throughout the analysis period. There are documented differences in the YSI 6600 model 6136 and YSI EXO turbidity sensors. There is no established relation between the YSI 6600 model 6136 and YSI EXO turbidity sensor models; therefore, individual models for each sensor were developed.

Discrete water-quality samples were collected during the analysis period and were analyzed for suspended-sediment concentration (SSC), sand-fine split percentage, and in most cases of high turbidity (greater than or equal to 500 formazin nephelometric units), five-point grain-size analysis. Silt and clay (less than 0.065 millimeter) composed more than 85 percent of selected high-flow samples by weight, indicating that turbidity as a surrogate for SSC was appropriate.

Regression models were updated from previous studies and developed using YSI 6600 and YSI EXO sensor turbidity data. Updated models had larger variance than previously published models but were still considered statistically similar. During the YSI 6600 deployment, low flow and drought conditions reduced available data collection, which could have contributed to the changes in variance that were observed between the previous and updated models. The new YSI EXO turbidity models, used for computations beginning in 2015 (various dates), explained 92-99 percent of the variance and included data collection over a wider range of hydrologic conditions compared to the YSI 6600 data. Compared to the streamflow-SSC linear regression models, the turbidity-SSC linear regression models explained 1.2-2.1 times more variance (adjusted coefficient of determination). Model statistics for the turbidity-SSC linear regression models were better (based on the coefficient of determination, root mean square error, and model standard percentage error) than the streamflow-SSC linear regression models, indicating better performance.

Regression-computed mean SSC was 40 percent greater at Cottonwood (179 milligrams per liter [mg/L]) than at Burlingame (108 mg/L). The mean SSC at Neosho Rapids (162 mg/L) was lower than the Cottonwood site by about 9 percent. Burlington had the smallest mean SSC among all four sites $(46 \mathrm{mg} / \mathrm{L})$.

During 2016 through 2019, there were discernible patterns in suspended-sediment concentrations, loads, and yields between the two upstream sites: Cottonwood and Burlingame. Cottonwood (the Cottonwood arm) consistently had larger estimated suspended-sediment concentrations and loads than Burlingame (the Upper Neosho arm). Suspended-sediment yields also were greater in all years, except in 2017 when Burlingame had an estimated 1 percent higher yield than Cottonwood. Cottonwood had higher yields than Neosho 
Rapids for 2016, 2018, and 2019. Otherwise, Neosho Rapids had higher estimated suspended-sediment concentrations and loads than either of the two upstream sites. Sediment transported downstream from John Redmond Reservoir to Burlington had substantially smaller concentrations, loads, and yields than what was transported into the reservoir at Neosho Rapids.

The mean daily suspended-sediment load at Cottonwood was 3.5 times larger $(2,180$ tons) than at Burlingame (624 tons). Neosho Rapids had the largest mean daily suspended-sediment load (2,250 tons; 3 percent larger than the mean daily suspended-sediment load at Cottonwood). Streamflow at Burlington was predominately regulated by the John Redmond Reservoir outflow just upstream. The mean daily suspended-sediment load at Burlington was the smallest of the four sites (286 tons), and Burlington consistently had the smallest annual suspended-sediment load throughout the analysis period. Compared to Neosho Rapids (upstream from John Redmond Reservoir), the mean daily suspendedsediment load at Burlington (downstream from reservoir) was 87 percent less. Computed suspended-sediment concentrations, loads, and yields only account for the gaged drainage area for each site. The ungaged 9 percent of the drainage basin below the Neosho Rapids streamgage was not included in the total estimation of suspended-sediment transported to John Redmond Reservoir.

During years with a complete data record at Neosho Rapids and Burlington (2010, 2014-19), the trapping efficiency of the reservoir ranged from 82 to 94 percent (mean: 89 percent) with the largest estimated amount of sediment trapped by the reservoir in 2019 (2,230,000 tons). In 2019, a total estimated load of 2,540,000 tons was transported into the reservoir (Neosho Rapids) and only 305,000 tons of sediment was estimated to have been transported out of the reservoir downstream (Burlington). As a result of increased precipitation and flooding in 2019, the reservoir lost an estimated 2,685 acre-feet (acre-ft) of reservoir storage because of sedimentation, and for years with complete annual datasets (2010, 2014-19), a total estimated 7,753 acre-ft of reservoir storage was lost. This does not include sediment loads that were retained during 2011-13 because those years had no associated turbidity data available at Burlington to estimate sediment concentrations and loads. By multiplying the mean trapping efficiency by Neosho Rapids suspended-sediment loads during years when no load data were available at Burlington (2011-13), the total estimated reservoir storage lost to sedimentation for the analysis period (2010-19) was about 8,690 acre-ft (mean annual load: 723,000 tons), about 17 percent of the remaining storage space reported in 2007. Different reservoir outflow management strategies, including operating near normal capacity as opposed to higher flood pool levels, could reduce the total reservoir storage lost by 3 percent (about 261 acre-ft). That potential sediment reduction is equal to 14 percent of the total sediment removed during the dredging operation. The mean annual sedimentation rate during the analysis period ( 747 acre-feet per year) was about 85 percent more than the sedimentation rate (404 acre-feet per year) originally projected during construction.

At the three sites upstream from the reservoir, 40-78 percent (mean: 56 percent) of the total suspended-sediment load was transported during streamflows above the National Weather Service flood action stage (Cottonwood mean: 48 percent; Burlingame mean: 40 percent; Neosho Rapids mean: 78 percent). Disproportionately large sediment loads are delivered during short periods of time, and localized efforts of stream erosion protection are likely to be overwhelmed. Precipitation frequency and intensity are projected to continue to increase in this region. Continued investigation of sediment reduction strategies is necessary with the understanding that sedimentation rate is largely driven by high flows. Changes to reservoir outflow management could also minimize sediment accumulation while still preserving flood control. Results from this study can be used to calibrate sediment models, explore sediment reduction strategies, highlight the importance of continued water-quality monitoring to determine effectiveness and changes in sediment transport, and assess the ability of John Redmond Reservoir to support designated uses into the future.

\section{References Cited}

Agel, L., Barlow, M., Colby, F., Binder, H., Catto, J.L., Hoell, A., and Cohen, J., 2019, Dynamical analysis of extreme precipitation in the US northeast based on large-scale meteorological patterns: Climate Dynamics, v. 52, no. 3-4, p. 1739-1760. [Also available at https://doi.org/10.1007/ s00382-018-4223-2.]

Agel, L., Barlow, M., Feldstein, S.B., and Gutowski, W.J., Jr., 2018, Identification of large-scale meteorological patterns associated with extreme precipitation in the US northeast: Climate Dynamics, v. 50, no. 5-6, p. 1819-1839. [Also available at https://doi.org/10.1007/s00382-017-3724-8.]

Anderson, C.W., 2005, Turbidity (ver. 2.1, September 2005): U.S. Geological Survey Techniques of Water-Resources Investigations, book 9, chap. 6.7, $55 \mathrm{p}$.

ASTM International, 2003, ASTM D1889-00 standard test method for turbidity of water: Conshohocken, Pa., ASTM International, v. $11.01,6 \mathrm{p}$.

Baird, D.C., Fotherby, L., Klumpp, C.C., and Sculock, S.M., 2015, Bank stabilization design guidelines: Denver, Colo., Bureau of Reclamation, SRH-2015-25, 331 p., accessed June 2020 at https://www.usbr.gov/tsc/techreferences/ mands/mands-pdfs/A-BankStab-final6-25-2015.pdf. 
Bennett, T.J., Graham, J.L., Foster, G.M., Stone, M.L., Juracek, K.E., Rasmussen, T.J., and Putnam, J.E., 2014, U.S. Geological Survey quality-assurance plan for continuous water-quality monitoring in Kansas, 2014: U.S. Geological Survey Open-File Report 2014-1151, 34 p. plus appendixes, accessed May 2020 at https://doi.org/10.3133/ ofr20141151.

Brady, N.C., and Weil, R.R., 1999, The nature and properties of soils 12th ed.: Upper Saddle River, N.J., PrenticeHall, 881 p.

Buchanan, R.C., ed., 1984, Kansas geology-An introduction to landscapes, rocks, minerals, and fossils: Lawrence, Kans., University Press of Kansas, 208 p.

Carswell, W.J., and Hart, R.J., 1985, Transit losses and travel times for reservoir releases during drought conditions along the Neosho River from Council Grove Lake to Iola, eastcentral Kansas: U.S. Geological Survey Water-Resources Investigations Report 85-4003, 40 p. [Also available at https://doi.org/10.3133/wri854003.]

Christensen, V.G., Ziegler, A.C., and Jian, X., 2000, Regression analysis and real-time water-quality monitoring to estimate constituent concentrations, loads, and yields in the Little Arkansas River, south-central Kansas, 1995-99: U.S. Geological Survey Water-Resources Investigations Report 2000-4126, 36 p. [Also available at https://doi.org/ 10.3133/wri004126.]

Collins, D.L., 1965, A general classification of source areas of fluvial sediment in Kansas: Kansas Geological Survey, Kansas Water Resources Board Bulletin 8, 21 p.

deNoyelles, F., and Kastens, J.H., 2016, Reservoir sedimentation challenges Kansas: Transactions of the Kansas Academy of Science, v. 119, no. 1, p. 69-81. [Also available at https://doi.org/10.1660/062.119.0110.]

Donohue, I., and Molinos, J.G., 2009, Impacts of increased sediment loads on the ecology of lakes: Biological Reviews of the Cambridge Philosophical Society, v. 84, no. 4, p. 517-531. [Also available at https://doi.org/10.1111/ j.1469-185X.2009.00081.x.]

Duan, N., 1983, Smearing estimate-A nonparametric retransformation method: Journal of the American Statistical Association, v. 78, no. 383, p. 605-610. [Also available at https://doi.org/10.1080/01621459.1983.10478017.]

Eash, D.A., and Barnes, K.K., 2017, Methods for estimating selected low-flow frequency statistics and harmonic mean flows for streams in Iowa (ver. 1.1, November 2017): U.S. Geological Survey Scientific Investigations Report 2012-5171, 99 p., accessed June 2020 at https://doi.org/ $10.3133 / \operatorname{sir} 20125171$.
Enlow, H.K., Fox, G.A., Boyer, T.A., Stoecker, A., Storm, D.E., Starks, P., and Guertault, L., 2018, A modeling framework for evaluating streambank stabilizing practices for reach-scale sediment reduction: Environmental Modelling \& Software, v. 100, p. 201-212. [Also available at https://doi.org/10.1016/j.envsoft.2017.11.010.]

Foster, G.M., 2014, Relations between continuous real-time turbidity data and discrete suspended-sediment concentration samples in the Neosho and Cottonwood Rivers, east-central Kansas, 2009-2012: U.S. Geological Survey Open-File Report 2014-1171, 20 p., accessed May 2020 at https://doi.org/10.3133/ofr20141171.

Foster, G.M., 2016, Effects of May through July 2015 storm events on suspended sediment loads, sediment trapping efficiency, and storage capacity of John Redmond Reservoir, east-central Kansas: U.S. Geological Survey Scientific Investigations Report 2016-5040, 10 p., accessed May 2020 at https://doi.org/10.3133/sir20165040.

Foster, G.M., Lee, C.J., and Ziegler, A.C., 2012, Sediment transport to and from small impoundments in northeast Kansas, March 2009 through September 2011: U.S. Geological Survey Scientific Investigations Report 2012-5269, 38 p., accessed May 2020 at https://doi.org/ $10.3133 / \operatorname{sir} 20125269$.

Fox, G.A., Sheshukov, A., Cruse, R., Kolar, R.L., Guertault, L., Gesch, K.R., and Dutnell, R.C., 2016, Reservoir sedimentation and upstream sediment sources-Perspectives and future research needs on streambank and gully erosion: Environmental Management, v. 57, no. 5, p. 945-955. [Also available at https://doi.org/10.1007/s00267-016-0671-9.]

Graham, J.L., Foster, G.M., Williams, T.J., Mahoney, M.D., May, M.R., and Loftin, K.A., 2018, Water-quality conditions with an emphasis on cyanobacteria and associated toxins and taste-and-odor compounds in the Kansas River, Kansas, July 2012 through September 2016: U.S. Geological Survey Scientific Investigations Report 2018-5089, 55 p. [Also available at https://doi.org/10.3133/ $\operatorname{sir} 20185089$.]

Guy, H.P., 1969, Laboratory theory and methods for sediment analysis: U.S. Geological Survey Techniques of WaterResources Investigations, book 5, chap. C1, 58 p. [Also available at https://pubs.usgs.gov/twri/twri5c1/.]

Helsel, D.R., Hirsch, R.M., Ryberg, K.R., Archfield, S.A., and Gilroy, E.J., 2020, Statistical methods in water resources: U.S. Geological Survey Techniques and Methods, book 4, chap. A3, 458 p. [Also available at https://doi.org/10.3133/ tm4a3.] [Supersedes U.S. Geological Survey Techniques of Water-Resources Investigations, book 4, chap. A3, ver. 1.1.] 
Henley, W.F., Patterson, M.A., Neves, R.J., and Lemly, A.D., 2000, Effects of sedimentation and turbidity on lotic food webs-A concise review for natural resource managers: Reviews in Fisheries Science, v. 8, no. 2, p. 125-139. [Also available at https://doi.org/10.1080/10641260091129198.]

Homer, C., Huang, C., Yang, L., Wylie, B., and Coan, M., 2004, Development of a 2001 National Land-Cover Database for the United States: American Society for Photogrammetry and Remote Sensing, (7): p. 829-840. [Also available at https://doi.org/10.14358/PERS.70.7.829.]

Jakubauskas, M., deNoyelles, J., and Martinko, E., 2014, Bathymetric survey of John Redmond Reservoir, Coffey County, Kansas: Applied Science and Technology for Reservoir Assessment (ASTRA) Program, Report 2014-01, 17 p. [Also available at https://biosurvey.ku.edu/sites/ biosurvey.ku.edu/files/publishedworks/pdfs/John\%20R edmond $\% 20$ bathymetric\%20survey\%202014.pdf.]

Jin, S., Homer, C.G., Yang, L., Danielson, P., Dewitz, J., Li, C., Zhu, Z., Xian, G., and Howard, D., 2019, Overall methodology design for the United States National Land Cover Database 2016 products: Remote Sensing, v. 11, no. 24, art. 2971, 32 p. [Also available at https://doi.org/10.3390/ rs11242971.]

Jordan, P.R., and Hart, R.J., 1985, Transit losses and travel times for water-supply releases from Marion Lake during drought conditions, Cottonwood River, east-central Kansas: U.S. Geological Survey Water-Resources Investigations Report 85-4263, 41 p. [Also available at https://doi.org/ 10.3133/wri854263.]

Juracek, K.E., 2001, Channel-bed elevation changes downstream from large reservoirs in Kansas: U.S. Geological Survey Water-Resources Investigations Report 2001-4205, 24 p. [Also available at https://doi.org/10.3133/wri014205.]

Juracek, K.E., 2010, Sedimentation, sediment quality, and upstream channel stability, John Redmond Reservoir, east-central Kansas, 1964-2009: U.S. Geological Survey Scientific Investigations Report 2010-5191, 34 p. [Also available at https://doi.org/10.3133/sir20105191.]

Juracek, K.E., 2011, Suspended-sediment loads, reservoir sediment trap efficiency, and upstream and downstream channel stability for Kanopolis and Tuttle Creek Lakes, Kansas, 2008-10: U.S. Geological Survey Scientific Investigations Report 2011-5187, 35 p., accessed May 2020 at https://doi.org/10.3133/sir20115187.
Kansas Department of Health and Environment, 2018a, 2018 303(d) list of all impaired \& potentially impaired waters: Kansas Department of Health and Environment, 56 p., accessed September 12, 2019, at https://www.kdheks.gov/ tmdl/2018/Approved_2018_303_d)_List_of_All_Impaired Waters.pdf.

Kansas Department of Health and Environment, 2018b, Kansas surface water quality standards: Kansas Department of Health and Environment, 73 p., accessed November 15, 2020, at https://www.kdheks.gov/tmdl/download/ Unofficial_Copy_SURFACE_WATER_QUALITY_ STANDARDS_04.11.18.pdf.

Kansas Water Office, 2017, John Redmond Reservoir dredging project—Phase I complete: Kansas Water Office, press release, June 9, 2017, accessed July 26, 2020, at https://kwo.ks.gov/news-events/press-releases/2017/06/ 09/john-redmond-reservoir-dredging-project--phase-icomplete-october-2016.

Kansas Water Office, 2018, State of the resource \& regional goal action plan implementation-Neosho regional planning area: Kansas Water Office, 23 p., accessed on May 26, 2020, at https://kwo.ks.gov/water-vision-water-plan/stateof-the-resource.

Kansas Water Office, 2019, Kansas water supply reservoirsCurrent capacity due to sedimentation: Kansas Water Office poster, 1 p. accessed January 4, 2020, at htt ps://www.kwo.ks.gov/docs/default-source/reservoirs/ current-capacity.pdf?sfvrsn=aca98514_0.

Kansas Water Office, 2020, John Redmond Reservoir watershed streambank projects: Kansas Water Office web page, accessed July 31, 2020, at https://kwo.ks.gov/projects/johnredmond-streambank.

Kennedy, E.J., 1984, Discharge ratings at gaging stations: U.S. Geological Survey Techniques of Water-Resource Investigations, book 3, chap. A10, 59 p., accessed May 26, 2020, at https://pubs.usgs.gov/twri/twri3-a10/.

Kloesel, K., Bartush, B., Banner, J., Brown, D., Lemery, J., Lin, X., Loeffler, C., McManus, G., Mullens, E., NielsenGammon, J., Shafer, M., Sorensen, C., Sperry, S., Wildcat, D., and Ziolkowska, J., 2018: Southern great plains, chap. 23 of Reidmiller, D.R., Avery, C.W., Easterling, D.R., Kunkel, K.E., Lewis, K.L.M., Maycock, T.K., and Stewart, B.C., eds., Impacts, risks, and adaptation in the United States-Fourth National Climate Assessment, volume II: Washington, D.C., U.S. Global Change Research Program, p. 987-1035. [Also available at https://doi.org/10.7930/ NCA4.2018.CH23.] 
Layzell, A.L., and Peterson, A., 2020, Assessing the effectiveness of streambank stabilization projects on the Cottonwood River using Unmanned Aircraft Systems: Kansas Geological Survey Open-File Report 2020-16, 16p., accessed March 29, 2021, at http://www.kgs.ku.edu/ Publications/OFR/2020/OFR2020-16.pdf.

Lee, C.J., and Foster, G.M., 2013, Assessing the potential of reservoir outflow management to reduce sedimentation using continuous turbidity monitoring and reservoir modeling: Hydrological Processes, v. 27, no. 10, p. 1426-1439. [Also available at https://doi.org/10.1002/hyp.9284.]

Lee, C.J., Rasmussen, P.P., and Ziegler, A.C., 2008, Characterization of suspended-sediment loading to and from John Redmond Reservoir, east-central Kansas, 2007-2008: U.S. Geological Survey Scientific Investigations Report 2008-5123, 25 p. [Also available at https://doi.org/10.3133/ sir20085123.]

Luoma, S.N., and Rainbow, P.S., 2008, Metal contamination in aquatic environments-Science and lateral management: New York, N.Y., Cambridge University Press, 588 p.

Menne, M.J., Durre, I., Korzeniewski, B., McNeal, S., Thomas, K., Yin, X., Anthony, S., Ray, R., Vose, R.S., Gleason, B.E., and Houston, T.G., 2012a, Global Historical Climatology Network-Daily (GHCN-Daily) (ver. 3.26): National Oceanic and Atmospheric Administration, digital data, accessed March 2020 at https://www.ncdc.noaa.gov/ ghcnd-data-access.

Menne, M.J., Durre, I., Vose, R.S., Gleason, B.E., and Houston, T.G., 2012b, An overview of the Global Historical Climatology Network-Daily database: Journal of Atmospheric and Oceanic Technology, v. 29, no. 7, p. 897-910. [Also available at https://doi.org/10.1175/ JTECH-D-11-00103.1.]

National Integrated Drought Information System, 2020, Drought in Kansas: National Integrated Drought Information System web page, accessed June 2, 2020, at https://www.drought.gov/drought/states/kansas.

National Oceanic and Atmospheric Administration, 2018, Global Historical Climatology Network-Daily (GHCNDaily), version 3: National Oceanic and Atmospheric Administration web page, accessed May 22, 2020, at https://doi.org/10.7289/V5D21VHZ.

National Regulatory Council, 2006, Wolf Creek Generating Station-Applicant's environmental report-Operating license renewal stage: National Regulatory Council, Docket No. 50-483, License No. NPF-42, accessed June 16, 2020, at https://www.nrc.gov/reactors/operating/licensing/ renewal/applications/wolf-creek/wcnoc-er.pdf.
Owens, P.N., Batalla, R.J., Collins, A.J., Gomez, B., Hicks, D.M., Horowitz, A.J., Kondolf, G.M., Marden, M., Page, M.J., Peacock, D.H., Petticrew, E.L., Salomons, W., and Trustrum, N.A., 2005, Fine-grained sediment in river systems-Environmental significance and management issues: River Research and Applications, v. 21, no. 7, p. 693-717.

Painter, C.C., and Loving, B.L., 2015, U.S. Geological Survey quality-assurance plan for surface-water activities in Kansas, 2015: U.S. Geological Survey Open-File Report 2015-1074, 33 p., accessed March 2020 at https://doi.org/ 10.3133/ofr20151074.

Porterfield, G., 1972, Computation of fluvial-sediment discharge: U.S. Geological Survey Techniques of WaterResources Investigations, book 3, chap. C3, 66 p. [Also available at https://doi.org/10.3133/twri03C3.]

Purvis, R.A., and Fox, G.A., 2016, Streambank sediment loading rates at the watershed scale and the benefit of riparian protection: Earth Surface Processes and Landforms, v. 41, no. 10, p. 1327-1336. [Also available at https://doi.org/ 10.1002/esp.3901.]

Putnam, J.E., and Pope, L.M., 2003, Trends in suspendedsediment concentration at selected stream sites in Kansas, 1970-2002: U.S. Geological Survey Water-Resources Investigations Report 2003-4150, 36 p. [Also available at https://doi.org/10.3133/wri034150.]

Rahmani, V., Kastens, J.D., deNoyelles, F., Jakubauskas, M.E., Martinko, E.A., Huggins, D.H., Gnau, C., Liechti, P.M., Campbell, S.E., Callihan, R.A., and Blackwood, A.J., 2018, Examining storage capacity loss and sedimentation rate of large reservoirs in central U.S. Great Plains: Water, v. 10 , no. 2 , art. 190,17 p. [Also available at https://doi.org/ $10.3390 /$ w10020190.]

Rasmussen, P.P., Gray, J.R., Glysson, G.D., and Ziegler, A.C., 2009, Guidelines and procedures for computing time-series suspended-sediment concentrations and loads from in-stream turbidity-sensor and streamflow data: U.S. Geological Survey Techniques and Methods, book 3, chap. C4, 54 p. [Also available at https://doi.org/10.3133/tm3c4.]

Rasmussen, T.J., Lee, C.J., and Ziegler, A.C., 2008, Estimation of constituent concentrations, loads, and yields in streams of Johnson County, northeast Kansas, using continuous waterquality monitoring and regression models, October 2002 through December 2006: U.S. Geological Survey Scientific Investigations Report 2008-5014, 104 p. [Also available at https://doi.org/10.3133/sir20085014.] 
Rasmussen, T.J., Ziegler, A.C., and Rasmussen, P.P., 2005, Estimation of constituent concentrations, densities, loads, and yields in lower Kansas River, northeast Kansas, using regression models and continuous water-quality monitoring, January 2000 through December 2003: U.S. Geological Survey Scientific Investigations Report 2005-5165, 117 p. [Also available at https://doi.org/10.3133/sir20055165.]

Sauer, V.B., and Turnipseed, D.P., 2010, Stage measurement at gaging stations: U.S. Geological Survey Techniques and Methods, book 3, chap. A7, 45 p., accessed March 2020 at https://doi.org/10.3133/tm3A7.

Schoewe, W.H., 1949, The geography of Kansas—Part II, physical geography: Transactions of the Kansas Academy of Science, v. 52, no. 3, p. 261-333. [Also available at https://doi.org/10.2307/3625794.]

Shafer, M., Ojima, D., Antle, J.M., Kluck, D., McPherson, R.A., Petersen, S., Scanlon, B., and Sherman, K., 2014, Great Plains, chap. 19 of Melillo, J.M., Richmond, T.C., and Yohe, G.W., eds., Climate change impacts in the United States-The Third National Climate Assessment: U.S. Global Change Research Program, p. 441-461. [Also available at https://doi.org/10.7930/J0D798BC.]

Simon, A., Curini, A., Darby, S.E., and Langendoen, E.J., 2000, Bank and near-bank processes in an incised channel: Geomorphology, v. 35, no. 3-4, p. 193-217. https://doi.org/ 10.1016/S0169-555X(00)00036-2.

Southard, R.E., 2013, Computed statistics at streamgages, and methods for estimating low-flow frequency statistics and development of regional regression equations for estimating low-flow frequency statistics at ungaged locations in Missouri: U.S. Geological Survey Scientific Investigations Report 2013-5090, 28 p. [Also available at https://doi.org/ 10.3133/sir20135090.]

Stone, M.L., Graham, J.L., and Gatotho, J.W., 2013, Continuous real-time water-quality monitoring and regression analysis to compute constituent concentrations and loads in the North Fork Ninnescah River upstream from Cheney Reservoir, south-central Kansas, 1999-2012: U.S. Geological Survey Scientific Investigations Report 2013-5071, 46 p., accessed May 2020 at https://doi.org/ 10.3133/sir20135071.

Stone, M.L., Juracek, K.E., Graham, J.L., and Foster, G.M., 2015, Quantifying suspended sediment loads delivered to Cheney Reservoir, Kansas - Temporal patterns and management implications: Journal of Soil and Water Conservation, v. 70, no. 2, p. 91-100. [Also available at https://doi.org/ 10.2489/jswc.70.2.91.]
Stone, M.L., Klager, B.J., and Ziegler, A.C., 2019, Waterquality and geochemical variability in the Little Arkansas River and Equus Beds aquifer, south-central Kansas, 2001-16: U.S. Geological Survey Scientific Investigations Report 2019-5026, 79 p., accessed May 2020 at https://doi.org/10.3133/sir20195026.

Straub, T.D., Johnson, G.P., Roseboom, D.P., and Sierra, C.R., 2006, Suspended-sediment yields and stream channel processes on Judy's Branch watershed in the St. Louis Metro East region in Illinois: U.S. Geological Survey Scientific Investigations Report 2006-5016, $51 \mathrm{p}$. [Also available at https://doi.org/10.3133/sir20065016.]

Turnipseed, D.P., and Sauer, V.B., 2010, Discharge measurements at gaging stations: U.S. Geological Survey Techniques and Methods, book 3, chap. A8, 87 p., accessed March 2020 at https://doi.org/10.3133/tm3A8.

U.S. Army Corps of Engineers, 2002, Streambank and shoreline protection manual: U.S. Army Corps of Engineers, 23 p., accessed June 16, 2020, at https://www.Irc.usace .army.mil/Portals/36/docs/regulatory/pdf/StrmManual.pdf.

U.S. Army Corps of Engineers, 2005, Initial appraisal of the Neosho River logjam, John Redmond Reservoir, Kansas: U.S. Army Corps of Engineers, 81 p., accessed June 11, 2020, at https://kgi.contentdm.oclc.org/digital/collection/ p16884coll78/id/135/.

U.S. Army Corps of Engineers, 2013, Final supplement to the final environmental statement, storage reallocation-John Redmond Dam and Reservoir, Kansas: Tulsa, Okla., U.S. Army Corps of Engineers, v. 1, [variously paged], accessed January 23, 2020, at https://www.swt.usace.army.mil/ Portals/41/docs/library/john_redmond/VOL_I_JRR $\% 20$ FINAL_SFES\%2020130212.pdf.

U.S. Army Corps of Engineers, 2016, John Redmond Dam and Reservoir master plan-Neosho River, Coffey and Lyon County, Kansas: Tulsa, Okla., U.S. Army Corps of Engineers, [variously paged], accessed January 23, 2020, at https://www.swt.usace.army.mil/Portals/41/docs/ library/john_redmond/John\%20Redmond\%20MP\%20Rev ision\%20(Draft)\%2020160126.pdf.

U.S. Army Corps of Engineers, 2019a, Dam safety newsletter-Summer 2019: U.S. Army Corps of Engineers, 4 p., accessed July 1, 2020, at https://usace.contentdm .oclc.org/digital/api/collection/p16021 coll8/id/4072/ download.

U.S. Army Corps of Engineers, 2019b, Monthly charts for Council Grove Lake: U.S Army Corps of Engineers web page, accessed June 1, 2020, at https://www.swtwc.usace.army.mil/COUNcharts.html. 
U.S. Army Corps of Engineers, 2019c, Monthly charts for John Redmond Lake: U.S Army Corps of Engineers web page, accessed June 1, 2020, at https://www.swtwc.usace.army.mil/JOHNcharts.html.

U.S. Army Corps of Engineers, 2019d, Monthly charts for Marion Lake: U.S Army Corps of Engineers web page, accessed June 1, 2020, at https://www.swtwc.usace.army.mil/MARIcharts.html.

U.S. Department of Agriculture, 2019, Web Soil Survey home: U.S. Department of Agriculture web page, accessed December 27, 2019, at https://websoilsurvey.sc.egov .usda.gov/App/HomePage.htm.

U.S. Environmental Protection Agency, 2000, Ambient water quality criteria recommendations - Rivers and streams in nutrient ecoregion IX: Washington, D.C., U.S. Environmental Protection Agency, EPA 822-B-00-019, [variously paged], accessed March 2020 at https://www.epa.gov/sites/production/files/documents/ rivers9.pdf.

U.S. Environmental Protection Agency, 2001, Ambient water quality criteria recommendations - Rivers and streams in nutrient ecoregion IV: Washington, D.C., U.S. Environmental Protection Agency, EPA 822-B-01-013, [variously paged], accessed March 2020 at https://www.epa.gov/sites/production/files/documents/ rivers4.pdf.

U.S. Geological Survey, 2006, Collection of water samples (ver. 2.0, September 2006): U.S. Geological Survey Techniques of Water-Resources Investigations, book 9, chap. A4 [variously paged]. [Also available at https://doi.org/10.3133/twri09A4.]

U.S. Geological Survey, 2008, Field measurements, (edited by Wilde, F.D.): U.S. Geological Survey Techniques of WaterResources Investigations, book 9; chap A6, [variously paged], accessed November 2019 at https://doi.org/10.3133/ twri09A6.

U.S. Geological Survey, 2013, Water basics glossary: U.S. Geological Survey web page, accessed May 26, 2020, at https://water.usgs.gov/water-basics_glossary.html.
U.S. Geological Survey, 2020, USGS water data for the Nation: U.S. Geological Survey National Water Information System database, accessed January 2020, at https://doi.org/ 10.5066/F7P55KJN.

Wagner, R.J., Boulger, R.W., Jr., Oblinger, C.J., and Smith, B.A., 2006, Guidelines and standard procedures for continuous water-quality monitors - Station operation, record computation, and data reporting: U.S. Geological Survey Techniques and Methods, book 1, chap. D3, 51 p. [Also available at https://doi.org/10.3133/tm1D3.]

Waters, T.F., 1995, Sediment in streams-Sources, biological effects, and control—Bethesda, Md: American Fisheries Society, Monograph 7.

Wetzel, R.G., 2001, Limnology—Lake and River ecosystems (3d ed.): New York, N.Y., Academic Press, 1,024 p.

YSI Incorporated, 2007, YSI 6136 turbidity sensor specification sheet: YSI Incorporated, 2 p., accessed November 2019 at https://www.ysi.com/File\%20Library/Documents/ Specification\%20Sheets/E56-6136-Turbidity-Sensor.pdf.

YSI Incorporated, 2012a, 6-Series multiparameter water quality sondes-User manual (revision J): YSI Incorporated, 379 p., accessed November 2019 at https://www.ysi.com/ File\%20Library/Documents/Manuals/069300-YSI-6-SeriesManual-RevJ.pdf.

YSI Incorporated, 2012b, EXO water quality field sensorsFeatures, specifications, and comparability to YSI 6-Series sensors (revision B): YSI Incorporated, 14 p., accessed November 2019 at https://www.exowater.com/media/pdfs/ EXO-6Series-Sensor-Comparison.pdf.

YSI Incorporated, 2015, EXO wiped conductivity and temperature sensor, specification E113: YSI Incorporated, 2 p., accessed April 29, 2020, at https://www.ysi.com/File $\% 20$ Library/Documents/Specification\%20Sheets/E113_EXOWiped_CT-Spec-Sheet.pdf.

YSI Incorporated, 2019, Turbidity units and calibration solutions-YSI turbidity sensors: YSI Incorporated, 2 p., accessed November 2019 at https://www.ysi.com/File\%20 Library/Documents/Technical\%20Notes/T627_Turbidity_ Units_and_Calibration_Solutions.pdf. 


\section{Appendixes 1-12}

Model archive summaries for suspended-sediment concentration at U.S. Geological Survey sites in Kansas are available for download at https://doi.org/10.3133/sir20215037. 


\section{Appendix 13. Suspended-Sediment Sample Grain-Size Distribution by Weight for Samples with Turbidity Measurements Greater than 500 Formazin Nephelometric Units}

Generally, for water-quality samples collected when turbidity was greater than or equal to 500 formazin nephelometric units, an additional five-point grain-size analysis was requested from the laboratory. For those selected samples, suspended sediment was measured by weight for grain sizes of $0.002,0.004,0.008,0.016,0.031,0.065$, and 1 millimeter (mm; table 13.1, fig. 13.1). For suspended-sediment samples collected at Neosho River at Burlingame Road near Emporia, Kansas (U.S. Geological Survey [USGS] site 07179750 ) (number of samples [n] =13), silt and clay (less than $0.065 \mathrm{~mm}$ ) composed at least 91 percent by weight of the sample concentrations, and clay-sized particles (less than $0.004 \mathrm{~mm}$ ) composed 39-80 percent. For suspended-sediment samples collected at Cottonwood Road near Plymouth, Kans.
(USGS site 07182250$)(\mathrm{n}=11)$, silt and clay composed at least 85 percent of the sample concentrations, and clay-sized particles composed 30-68 percent. For suspended-sediment samples collected at Neosho River at Neosho Rapids, Kans. (USGS site 07182390) $(\mathrm{n}=25)$, silt and clay composed at least 86 percent by weight of the sample concentrations, and claysized particles composed 38-80 percent. For suspended-sediment samples collected at Neosho River at Burlington, Kans. (USGS site 07182510) $(n=5)$, silt and clay composed at least 97 percent by weight of the sample concentrations, and claysized particles composed 81-86 percent. Because fine particles (less than $0.065 \mathrm{~mm}$ ) dominated the composition of the transported suspended sediment, the use of turbidity as a surrogate for suspended-sediment concentrations was appropriate. 
Table 13.1. Loss on ignition, suspended-sediment concentration, and grain-size distribution of samples collected when turbidity exceeded 500 formazin nephelometric units.

[ID, identifier; Turb, field-measured turbidity; FNU, formazin nephelometric unit; LOI, loss on ignition; mg/L, milligram per liter; SSC, suspended-sediment concentration; Q, streamflow; $\mathrm{ft}^{3} / \mathrm{s}$, cubic foot per second; <, less than; mm, millimeter; USGS, U.S. Geological Survey; $n$, number of samples; 6136, turbidity from YSI Incorporated Extended Deployment System turbidity sensor model 6136, in formazin nephelometric units; --, no data; EXO, turbidity from Xylem YSI EXO, turbidity sensor, in formazin nephelometric units]

\begin{tabular}{|c|c|c|c|c|c|c|c|c|c|c|c|c|c|c|}
\hline \multirow{2}{*}{$\begin{array}{c}\text { Sample } \\
\text { ID }\end{array}$} & \multirow{2}{*}{$\begin{array}{c}\text { YSI } \\
\text { model }\end{array}$} & \multirow[b]{2}{*}{ Year } & \multirow[b]{2}{*}{ Month } & \multirow{2}{*}{$\begin{array}{c}\text { Turb } \\
\text { (FNU) }\end{array}$} & \multirow{2}{*}{$\begin{array}{c}\text { LOI } \\
\text { (mg/L) }\end{array}$} & \multirow{2}{*}{$\begin{array}{c}\text { SSC } \\
\text { (mg/L) }\end{array}$} & \multirow{2}{*}{$\begin{array}{c}0 \\
\left(\mathrm{ft}^{3} / \mathrm{s}\right)\end{array}$} & \multicolumn{7}{|c|}{ Sediment size fractions, in percent, of sample per sieve diameter } \\
\hline & & & & & & & & $<0.002 \mathrm{~mm}$ & $<0.004 \mathrm{~mm}$ & $<0.008 \mathrm{~mm}$ & $<0.016 \mathrm{~mm}$ & $<0.031 \mathrm{~mm}$ & $<0.065 \mathrm{~mm}$ & $\begin{array}{c}<1 \\
\mathrm{~mm}\end{array}$ \\
\hline \multicolumn{15}{|c|}{ Cottonwood River near Plymouth, Kansas (USGS site 07182250) ( $n=11$ ) } \\
\hline $\mathrm{C}-1$ & 6136 & 2007 & May & 1,078 & -- & 1,960 & 17,800 & 63 & 68 & 71 & 79 & 94 & 98 & 100 \\
\hline $\mathrm{C}-2$ & 6136 & 2008 & February & 764 & -- & 2,150 & 10,000 & 51 & 54 & 58 & 65 & -- & 96 & 100 \\
\hline $\mathrm{C}-3$ & 6136 & 2008 & May & 450 & -- & 1,090 & 10,500 & 48 & 53 & 57 & 63 & -- & 91 & 100 \\
\hline $\mathrm{C}-4$ & 6136 & 2008 & July & 206 & -- & 828 & 1,310 & 27 & 30 & 32 & 41 & -- & 85 & 100 \\
\hline $\mathrm{C}-5$ & EXO & 2016 & April & 971 & 406 & 3,100 & 3,300 & 45 & 51 & 60 & 72 & 92 & 98 & 100 \\
\hline$C-6$ & EXO & 2016 & April & 763 & 273 & 2,030 & 3,220 & 48 & 56 & 65 & 76 & 90 & 99 & 100 \\
\hline $\mathrm{C}-7$ & EXO & 2016 & April & 651 & 159 & 1,750 & 13,000 & 46 & 55 & 62 & 75 & 91 & 98 & 100 \\
\hline $\mathrm{C}-8$ & EXO & 2017 & March & 875 & 76 & 3,210 & 13,700 & 36 & 42 & 47 & 59 & 82 & 96 & 100 \\
\hline $\mathrm{C}-9$ & EXO & 2019 & March & 829 & 262 & 3,480 & 6,440 & 44 & 47 & 49 & 61 & 84 & 97 & 100 \\
\hline $\mathrm{C}-10$ & EXO & 2019 & May & 504 & 95 & 1,110 & 14,850 & 58 & 62 & 65 & 74 & 89 & 98 & 100 \\
\hline $\mathrm{C}-11$ & EXO & 2019 & August & 517 & 132 & 1,600 & 5,487 & 39 & 44 & 53 & 69 & 88 & 98 & 100 \\
\hline \multicolumn{15}{|c|}{ Neosho River at Burlingame Road near Emporia, Kansas (USGS site 07179750) ( $n=13)$} \\
\hline B-1 & 6136 & 2009 & September & 703 & 15 & 2,240 & 2,430 & 40 & 45 & 47 & 53 & 87 & 91 & 100 \\
\hline B-2 & 6136 & 2010 & July & 881 & 5 & 2,210 & 5,120 & 47 & 49 & 52 & 65 & 94 & 98 & 100 \\
\hline B-3 & 6136 & 2012 & March & 1,132 & 2 & 1,980 & 1,090 & 65 & 73 & 81 & 92 & 96 & 99 & 100 \\
\hline B- 4 & 6136 & 2012 & March & 392 & 2 & 760 & 1,890 & 63 & 63 & 66 & 76 & 92 & 98 & 100 \\
\hline B-5 & 6136 & 2012 & March & 313 & 1 & 567 & 2,200 & 60 & 66 & 70 & 78 & 93 & 97 & 100 \\
\hline B-6 & EXO & 2016 & April & 558 & 101 & 1,080 & 2,530 & 36 & 39 & 46 & 59 & 82 & 92 & 100 \\
\hline B-7 & EXO & 2016 & April & 661 & 105 & 1,420 & 11,100 & 52 & 59 & 67 & 77 & 92 & 99 & 100 \\
\hline B-8 & EXO & 2018 & September & 775 & 411 & 2,170 & 4,240 & 56 & 66 & 70 & 80 & 98 & 100 & -- \\
\hline B-9 & EXO & 2019 & February & 642 & 192 & 2,240 & 4,663 & 47 & 52 & 54 & 66 & 87 & 98 & 100 \\
\hline B-10 & EXO & 2019 & March & 580 & 156 & 2,120 & 3,100 & 48 & 50 & 54 & 61 & 82 & 97 & 100 \\
\hline B-11 & EXO & 2019 & March & 914 & 283 & 2,730 & 5,800 & 51 & 53 & 61 & 75 & 92 & 99 & 100 \\
\hline B-12 & EXO & 2019 & May & 556 & 187 & 1,600 & 10,100 & 56 & 64 & 67 & 75 & 93 & 99 & 100 \\
\hline B-13 & EXO & 2019 & May & 735 & 133 & 1,630 & 15,400 & 65 & 80 & 85 & 91 & 97 & 99 & 100 \\
\hline \multicolumn{15}{|c|}{ Neosho River at Neosho Rapids, Kansas (USGS site 07182390) ( $n=25)$} \\
\hline $\mathrm{R}-1$ & 6136 & 2009 & June & 586 & 2 & 1,110 & -- & 53 & 61 & 61 & 80 & 90 & 97 & 100 \\
\hline $\mathrm{R}-2$ & 6136 & 2009 & July & 744 & 2 & 965 & -- & 79 & 80 & 83 & 91 & 95 & 98 & 100 \\
\hline
\end{tabular}


Table 13.1. Loss on ignition, suspended-sediment concentration, and grain-size distribution of samples collected when turbidity exceeded 500 formazin nephelometric units.Continued

[ID, identifier; Turb, field-measured turbidity; FNU, formazin nephelometric unit; LOI, loss on ignition; mg/L, milligram per liter; SSC, suspended-sediment concentration; Q, streamflow; ft ${ }^{3} / \mathrm{s}$, cubic foot per second; <, less than; mm, millimeter; USGS, U.S. Geological Survey; $n$, number of samples; 6136, turbidity from YSI Incorporated Extended Deployment System turbidity sensor model 6136, in formazin nephelometric units; --, no data; EXO, turbidity from Xylem YSI EXO, turbidity sensor, in formazin nephelometric units]

\begin{tabular}{|c|c|c|c|c|c|c|c|c|c|c|c|c|c|c|}
\hline \multirow{2}{*}{$\begin{array}{c}\text { Sample } \\
\text { ID }\end{array}$} & \multirow{2}{*}{$\begin{array}{c}\text { YSI } \\
\text { model }\end{array}$} & \multirow[b]{2}{*}{ Year } & \multirow[b]{2}{*}{ Month } & \multirow{2}{*}{$\begin{array}{l}\text { Turb } \\
\text { (FNU) }\end{array}$} & \multirow{2}{*}{$\begin{array}{c}\text { LOI } \\
\text { (mg/L) }\end{array}$} & \multirow{2}{*}{$\begin{array}{c}\text { SSC } \\
\text { (mg/L) }\end{array}$} & \multirow{2}{*}{$\begin{array}{c}\mathbf{0} \\
\left(\mathrm{ftt}^{3} / \mathrm{s}\right)\end{array}$} & \multicolumn{7}{|c|}{ Sediment size fractions, in percent, of sample per sieve diameter } \\
\hline & & & & & & & & $<0.002 \mathrm{~mm}$ & $<0.004 \mathrm{~mm}$ & $<0.008 \mathrm{~mm}$ & $<0.016 \mathrm{~mm}$ & $<0.031 \mathrm{~mm}$ & $<0.065 \mathrm{~mm}$ & $\begin{array}{l}<1 \\
\mathrm{~mm}\end{array}$ \\
\hline \multicolumn{15}{|c|}{ Neosho River at Neosho Rapids, Kansas (USGS site 07182390) (n=25) - Continued } \\
\hline $\mathrm{R}-3$ & 6136 & 2009 & August & 896 & 2 & 2,120 & 3,620 & 48 & 49 & 50 & 75 & 94 & 99 & 100 \\
\hline $\mathrm{R}-4$ & 6136 & 2009 & September & 474 & 7 & 1,560 & 4,960 & 39 & 41 & 43 & 55 & 75 & 87 & 100 \\
\hline $\mathrm{R}-5$ & 6136 & 2010 & March & 784 & 147 & 2,420 & 4,980 & 39 & 43 & 46 & 62 & 87 & 98 & 100 \\
\hline $\mathrm{R}-6$ & 6136 & 2010 & June & 962 & 7 & 1,950 & 11,500 & 51 & 54 & 59 & 61 & 92 & 97 & 100 \\
\hline $\mathrm{R}-7$ & 6136 & 2010 & September & 141 & 1 & 286 & 922 & 45 & 54 & 57 & 69 & 90 & 98 & 100 \\
\hline $\mathrm{R}-8$ & 6136 & 2010 & September & 590 & 3 & 1,610 & 3,610 & 41 & 46 & 48 & 66 & 88 & 97 & 100 \\
\hline $\mathrm{R}-9$ & 6136 & 2011 & April & 1,022 & 1 & 1,610 & 1,970 & 68 & 80 & 85 & 96 & 98 & 100 & -- \\
\hline $\mathrm{R}-10$ & 6136 & 2012 & March & 811 & 4 & 1,930 & 2,180 & 53 & 57 & 65 & 76 & 94 & 98 & 100 \\
\hline $\mathrm{R}-11$ & 6136 & 2012 & March & 594 & 21 & 2,110 & 5,620 & 33 & 38 & 44 & 57 & 77 & 86 & 100 \\
\hline $\mathrm{R}-12$ & 6136 & 2012 & March & 710 & 4 & 1,750 & 9,600 & 52 & 54 & 56 & 69 & 91 & 97 & 100 \\
\hline $\mathrm{R}-13$ & 6136 & 2013 & August & 414 & 1 & 722 & 13,100 & 42 & 57 & 63 & 73 & 86 & 96 & 100 \\
\hline $\mathrm{R}-14$ & 6136 & 2013 & August & -- & 2 & 1,580 & 13,200 & 48 & 53 & 54 & 72 & 86 & 97 & 100 \\
\hline $\mathrm{R}-15$ & 6136 & 2014 & June & 1,254 & 265 & 4,230 & 6,630 & 32 & 38 & 45 & 56 & 74 & 88 & 100 \\
\hline $\mathrm{R}-16$ & EXO & 2015 & May & 667 & 103 & 1,220 & 18,500 & 74 & 79 & 83 & 86 & 96 & 98 & 100 \\
\hline $\mathrm{R}-17$ & EXO & 2015 & June & 568 & 205 & 1,440 & 10,600 & 48 & 57 & 63 & 71 & 92 & 100 & -- \\
\hline $\mathrm{R}-18$ & EXO & 2016 & April & 698 & 289 & 2,370 & 8,650 & 44 & 51 & 60 & 73 & 91 & 99 & 100 \\
\hline $\mathrm{R}-19$ & EXO & 2016 & April & 737 & 135 & 2,000 & 16,600 & 52 & 60 & 65 & 77 & 94 & 98 & 100 \\
\hline $\mathrm{R}-20$ & EXO & 2017 & March & 586 & 114 & 1,830 & 10,200 & 41 & 45 & 52 & 64 & 83 & 97 & 100 \\
\hline $\mathrm{R}-21$ & EXO & 2018 & September & 1,028 & 310 & 3,570 & 7,517 & 54 & 58 & 66 & 75 & 94 & 99 & 100 \\
\hline $\mathrm{R}-22$ & EXO & 2019 & February & 510 & 133 & 1,660 & 8,237 & 48 & 54 & 57 & 65 & 85 & 98 & 100 \\
\hline $\mathrm{R}-23$ & EXO & 2019 & March & 817 & 240 & 2,680 & 13,000 & 48 & 53 & 60 & 73 & 94 & 99 & 100 \\
\hline $\mathrm{R}-24$ & EXO & 2019 & May & 506 & 85 & 1,210 & 19,967 & 72 & 76 & 79 & 83 & 92 & 99 & 100 \\
\hline $\mathrm{R}-25$ & EXO & 2019 & May & 534 & 118 & 1,190 & 27,100 & 59 & 73 & 75 & 86 & 95 & 99 & 100 \\
\hline \multicolumn{15}{|c|}{ Neosho River at Burlington, Kansas (USGS site 07182510) $(n=5)$} \\
\hline BT-1 & EXO & 2019 & February & 28 & 9 & 45 & 7,190 & 78 & 81 & 84 & 88 & 92 & 98 & 100 \\
\hline BT-2 & EXO & 2019 & February & 93 & 26 & 134 & 4,500 & 81 & 86 & 89 & 92 & 96 & 99 & 100 \\
\hline $\mathrm{BT}-3$ & EXO & 2019 & March & 188 & 56 & 335 & 4,120 & 72 & 81 & 89 & 92 & 97 & 99 & 100 \\
\hline
\end{tabular}


Table 13.1. Loss on ignition, suspended-sediment concentration, and grain-size distribution of samples collected when turbidity exceeded 500 formazin nephelometric units.Continued

[ID, identifier; Turb, field-measured turbidity; FNU, formazin nephelometric unit; LOI, loss on ignition; $\mathrm{mg} / \mathrm{L}$, milligram per liter; SSC, suspended-sediment concentration; $\mathrm{Q}$, streamflow; $\mathrm{ft}^{3} / \mathrm{s}$, cubic foot per second; < less than; mm, millimeter; USGS, U.S. Geological Survey; $n$, number of samples; 6136, turbidity from YSI Incorporated Extended Deployment System turbidity sensor model 6136, in formazin nephelometric units; --, no data; EXO, turbidity from Xylem YSI EXO, turbidity sensor, in formazin nephelometric units]

\begin{tabular}{|c|c|c|c|c|c|c|c|c|c|c|c|c|c|c|}
\hline \multirow{2}{*}{$\begin{array}{c}\text { Sample } \\
\text { ID }\end{array}$} & \multirow{2}{*}{$\begin{array}{c}\text { YSI } \\
\text { model }\end{array}$} & \multirow[b]{2}{*}{ Year } & \multirow[b]{2}{*}{ Month } & \multirow{2}{*}{$\begin{array}{l}\text { Turb } \\
\text { (FNU) }\end{array}$} & \multirow{2}{*}{$\begin{array}{c}\text { LOI } \\
\text { (mg/L) }\end{array}$} & \multirow{2}{*}{$\begin{array}{c}\text { SSC } \\
(\mathrm{mg} / \mathrm{L})\end{array}$} & \multirow{2}{*}{$\begin{array}{c}0 \\
\left(\mathrm{ft}^{3} / \mathrm{s}\right)\end{array}$} & \multicolumn{7}{|c|}{ Sediment size fractions, in percent, of sample per sieve diameter } \\
\hline & & & & & & & & $<0.002 \mathrm{~mm}$ & $<0.004 \mathrm{~mm}$ & $<0.008 \mathrm{~mm}$ & $<0.016 \mathrm{~mm}$ & $<0.031 \mathrm{~mm}$ & $<0.065 \mathrm{~mm}$ & $\begin{array}{l}<1 \\
\mathrm{~mm}\end{array}$ \\
\hline \multicolumn{15}{|c|}{ Neosho River at Burlington, Kansas (USGS site 07182510) $(n=5)$-Continued } \\
\hline BT-4 & EXO & 2019 & April & 140 & 19 & 215 & 311 & 84 & 85 & 87 & 92 & 94 & 99 & 100 \\
\hline BT-5 & EXO & 2019 & May & 74 & 7 & 89 & 16,167 & 85 & 86 & 87 & 90 & 91 & 97 & 100 \\
\hline
\end{tabular}




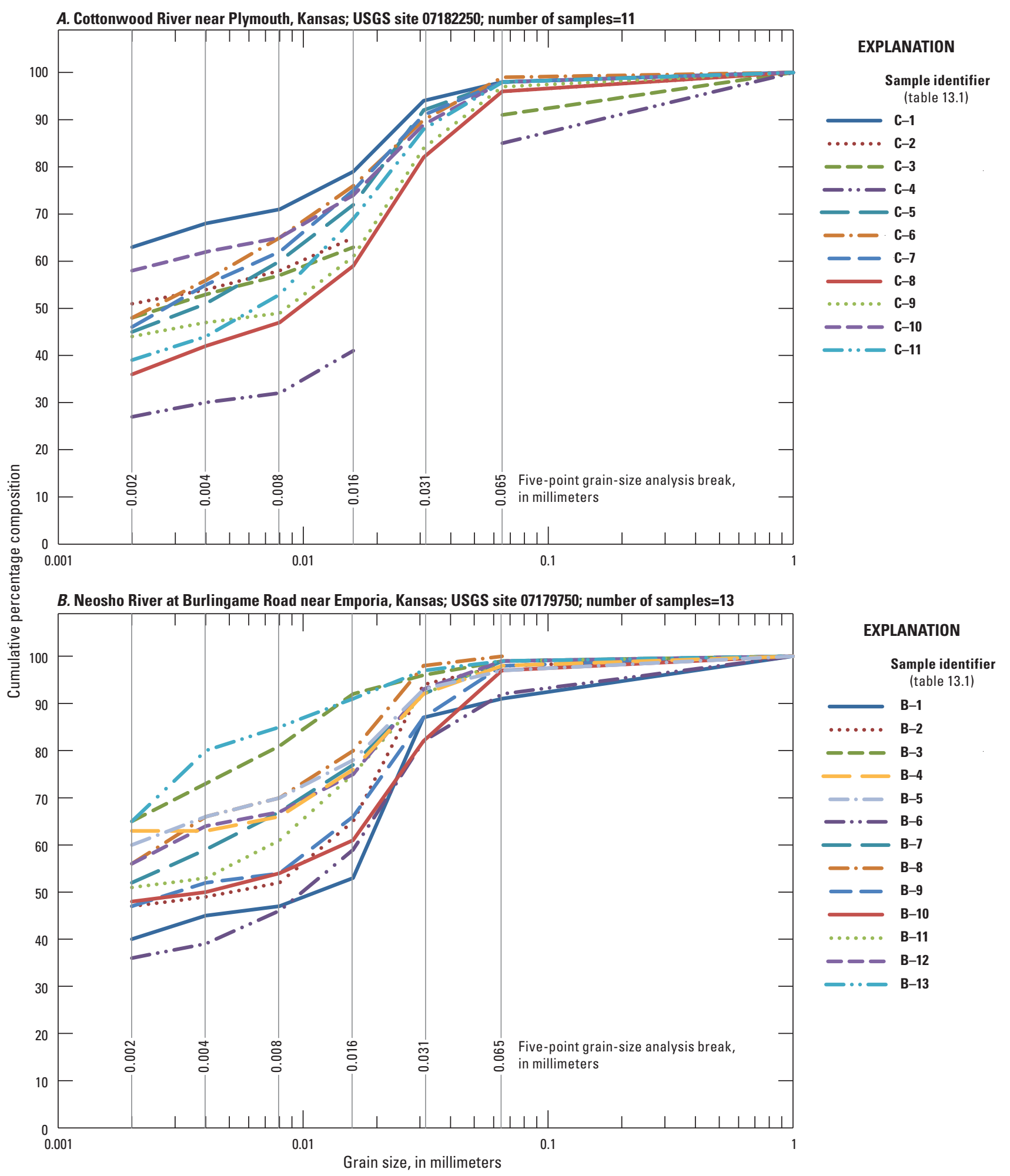

Figure 13.1. Grain size distribution for suspended-sediment samples with turbidities greater than 500 formazin nephelometric units for study sites along the Cottonwood and Neosho Rivers, Kansas, during 2007 through 2019. A, Cottonwood River near Plymouth (U.S. Geological Survey [USGS] site 07182250); B, Neosho River at Burlingame Road near Emporia (USGS site 07179750); $C$, Neosho River at Neosho Rapids (USGS site 07182390); D, Neosho River at Burlington (USGS site 07182510). 
C. Neosho River at Neosho Rapids, Kansas; USGS site 07182390; number of samples=25

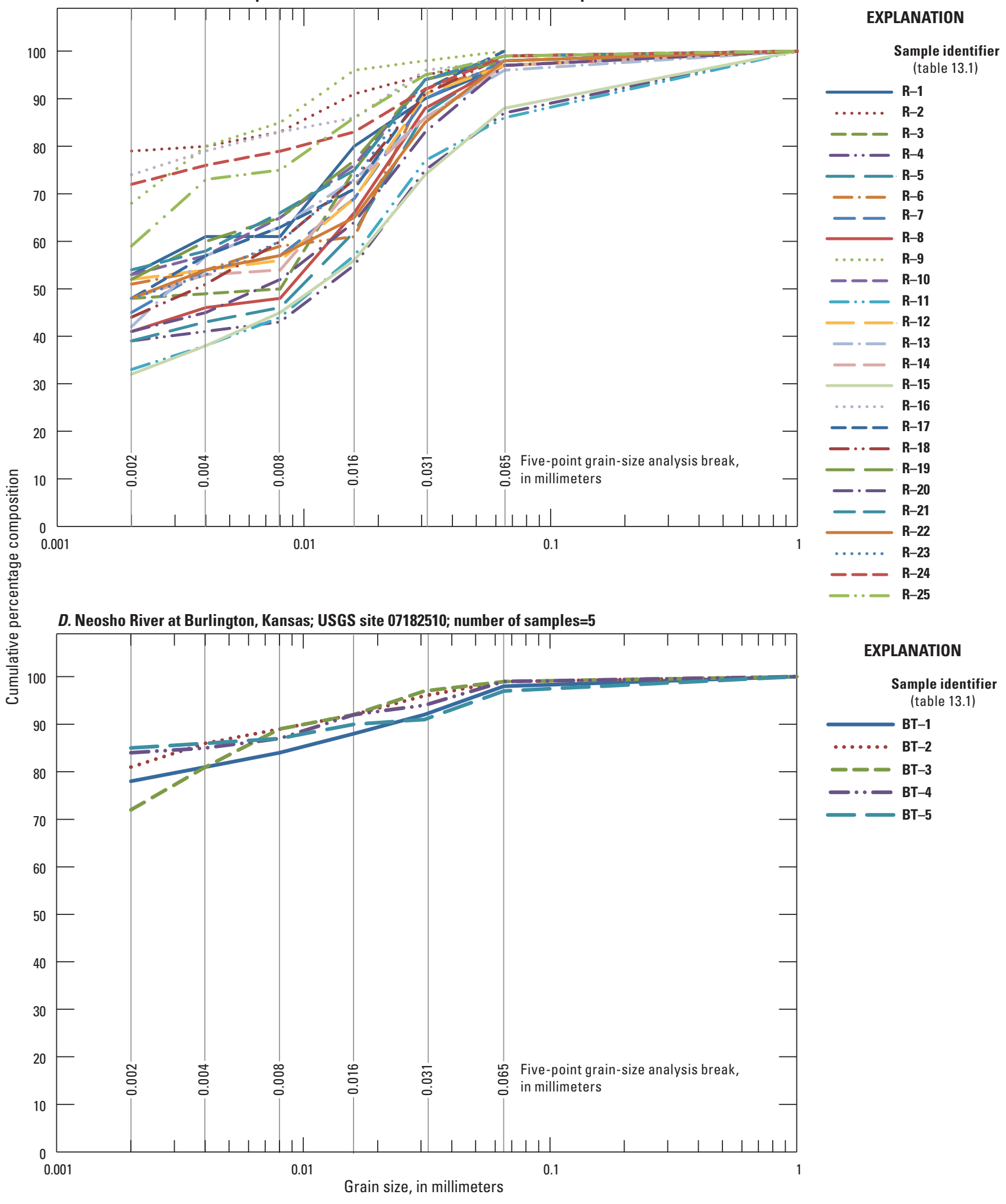

Figure 13.1. Grain size distribution for suspended-sediment samples with turbidities greater than 500 formazin nephelometric units for study sites along the Cottonwood and Neosho Rivers, Kansas, during 2007 through 2019. $A$, Cottonwood River near Plymouth (U.S. Geological Survey [USGS] site 07182250); $B$, Neosho River at Burlingame Road near Emporia (USGS site 07179750); $C$, Neosho River at Neosho Rapids (USGS site 07182390); D, Neosho River at Burlington (USGS site 07182510)—Continued. 
For more information about this publication, contact:

Director, USGS Kansas Water Science Center

1217 Biltmore Drive

Lawrence, KS 66049

785-842-9909

For additional information, visit: https://www.usgs.gov/centers/kswsc

Publishing support provided by the

Rolla Publishing Service Center 

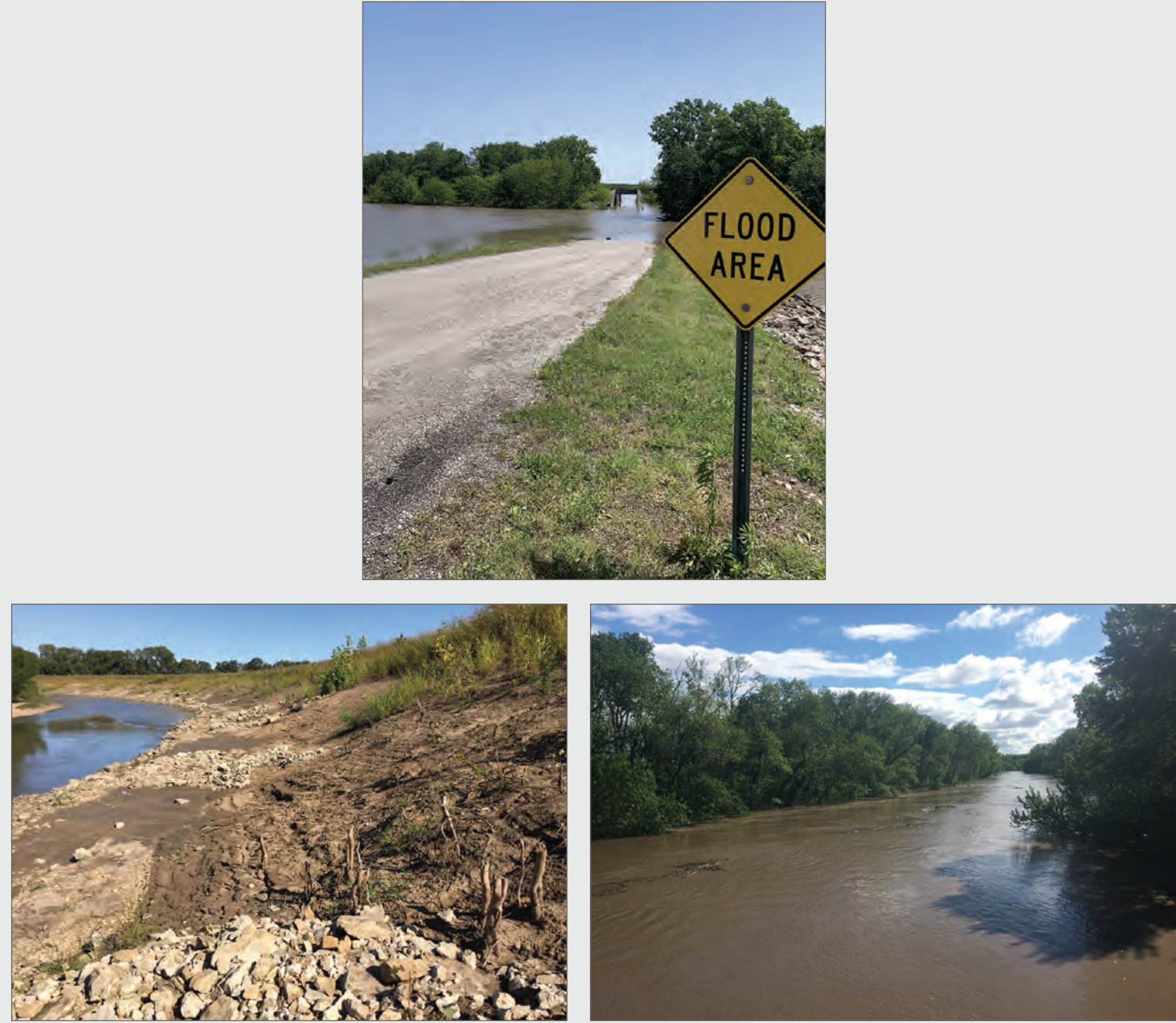